\title{
WestVirginiaUniversity
}

THE RESEARCH REPOSITORY @ WVU

Graduate Theses, Dissertations, and Problem Reports

2007

\section{Methods of season extension for market gardeners}

Natalie R. Bumgarner

West Virginia University

Follow this and additional works at: https://researchrepository.wvu.edu/etd

\section{Recommended Citation}

Bumgarner, Natalie R., "Methods of season extension for market gardeners" (2007). Graduate Theses, Dissertations, and Problem Reports. 2549.

https://researchrepository.wvu.edu/etd/2549

This Thesis is protected by copyright and/or related rights. It has been brought to you by the The Research Repository @ WVU with permission from the rights-holder(s). You are free to use this Thesis in any way that is permitted by the copyright and related rights legislation that applies to your use. For other uses you must obtain permission from the rights-holder(s) directly, unless additional rights are indicated by a Creative Commons license in the record and/ or on the work itself. This Thesis has been accepted for inclusion in WVU Graduate Theses, Dissertations, and Problem Reports collection by an authorized administrator of The Research Repository @ WVU. For more information, please contact researchrepository@mail.wvu.edu. 


\title{
Methods of Season Extension for Market Gardeners
}

\author{
Natalie R. Bumgarner
}

Thesis submitted to the

Davis College of Agriculture, Forestry, and Consumer Sciences

at West Virginia University

in partial fulfillment of the requirements

for the degree of

Master of Science

in

Horticulture

Sven Verlinden, Ph.D., Chair

William Bryan, Ph.D.

Todd West, Ph.D.

Division of Plant and Soil Sciences

Morgantown, West Virginia

2007

Keywords: Vegetable production, Organic agriculture, Row covers, Low tunnels, Season extension, Cold frames 


\section{Abstract \\ Methods of Season Extension for Market Gardeners}

\section{Natalie R. Bumgarner}

Season extension methods have been used in many climates and crops for centuries on all scales of vegetable production. Our research compared the effect of six season extension methods on soil and ambient temperatures and yields of warm and cool season vegetables in organic production. The methods under investigation in field plots were row cover, row cover with water tubes, low tunnel, low tunnel with water tubes, and a control for comparison, which were all replicated three times in field plots. The cold frame, and cold frame with water buffer treatments were replicated once in separate structures. Radishes, lettuce, peppers, tomatoes, and arugula were grown in the spring and fall of 2006 and the spring of 2007. Plantings were scheduled according to the level of protection expected for each treatment. Air and soil temperatures were measured throughout the growing seasons. Both early (harvested before the control) and total fruit, root, and leaf yields were recorded. Air and soil temperatures in the experimental treatments were generally higher than the control. Cold frame temperatures were the highest, followed by row covers and low tunnel temperatures, which were sometimes similar to the control. The inclusion of water in plastic tubes showed trends toward increased temperatures, but these trends were rarely significant. The total yields for warm season crops in the field plot treatments were higher than the control. Cool season crops in the field plot treatments did not show differences only trends towards increased yield because of their lower temperature requirements. The total yield in the two cold frame treatments was higher than the field plot treatments in all crops for both years. Early fruit yields were higher for the warm season crops in the field plots and in the cold frames, with much higher early yields observed in the cold frames. The water tubes in the field plots significantly increased yields in pepper crops for both years even though temperature was not always affected. Harvests were extended for up to four weeks in the spring. These results show potential for extended growth and profitability, especially in warm season vegetable crops using season extension methods. Yield increases were most pronounced in the pepper crop. Cold frame treatments showed the highest yield and profitability. Row covers with water tubes would be a lower cost alternative to cold frames if lower initial costs are desired. 


\section{Acknowledgments}

My time spent here in Morgantown at WVU working on this project has really been a pleasant and wonderful learning experience. I owe my gratitude to both Dr. Baker and Dr. Verlinden for having faith in my abilities and supporting me in these last two and a half years on this experiment and in the three previous years as an undergraduate. I would also like to thank my committee members Dr. Bryan and Dr. West for their assistance and encouragement. Additional thanks go to Dr. Wearden and Dr. Kotcon for their help with statistics and my data analysis. I also owe my big brother Nathan and the horticulture Bryans a huge debt of gratitude for their knowledge and assistance as I worked on my first ever construction project when building the cold frames. It would be quite fair to say that without a little power tool assistance this project would never have even gotten started. I also need to mention how invaluable Evan Anderson and Marvin Clark were when it came to really getting things done at the farm. 


\section{Table of Contents}

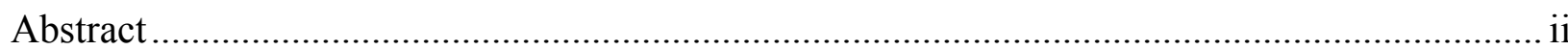

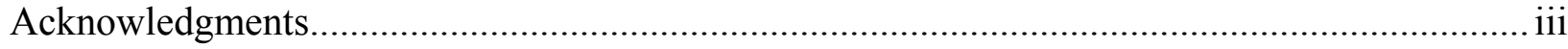

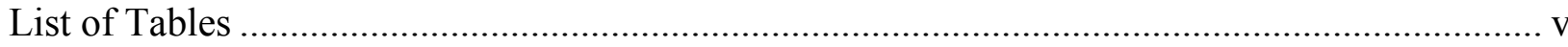

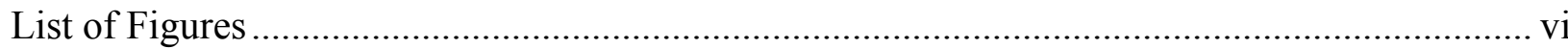

Chapter 1-Introduction and Literature Review ....................................................................... 1

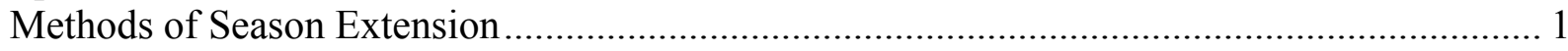

Overview and Goals................................................................................................... 11

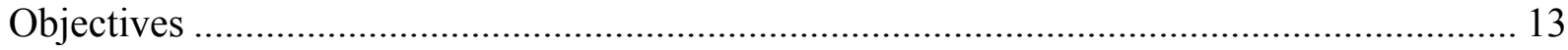

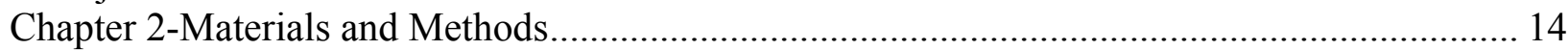

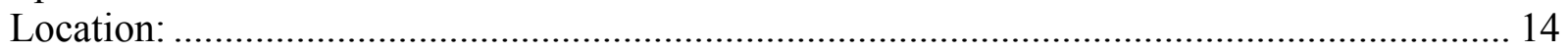

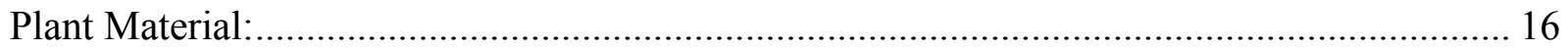

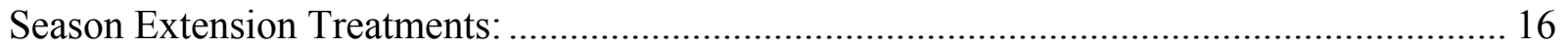

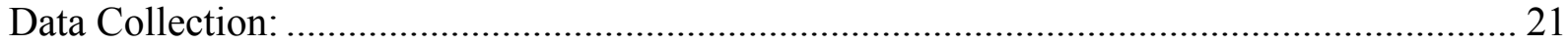

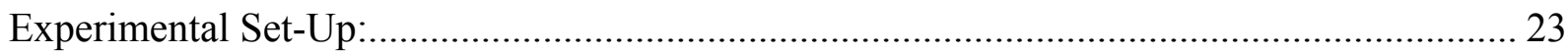

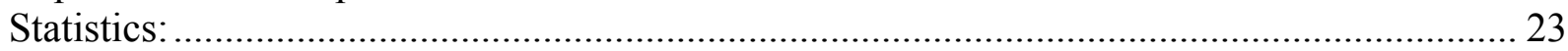

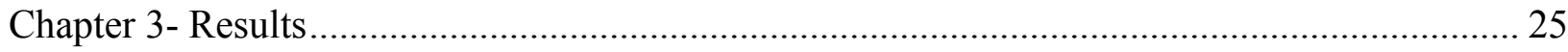

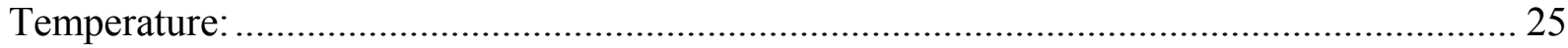

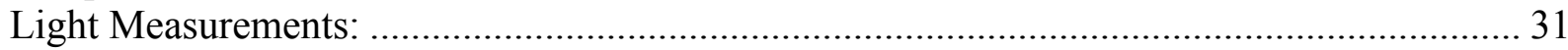

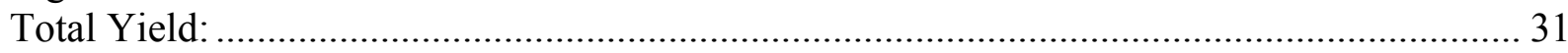

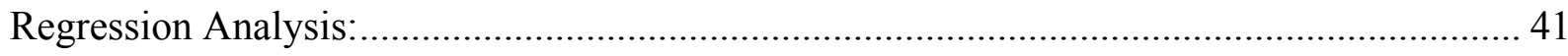

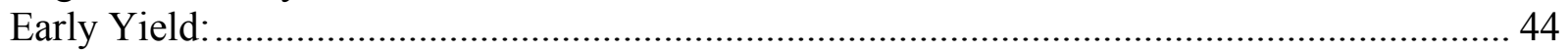

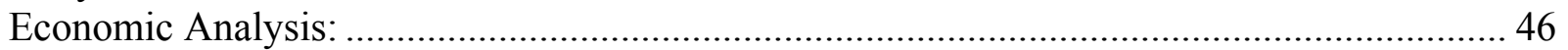

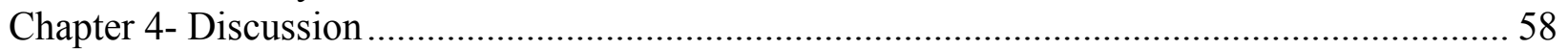

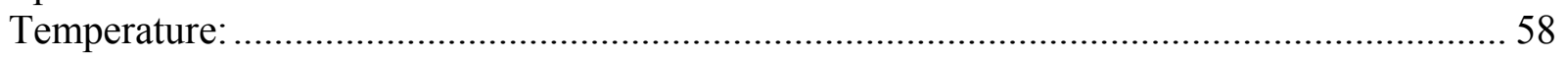

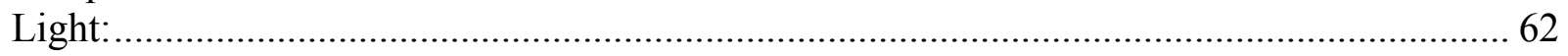

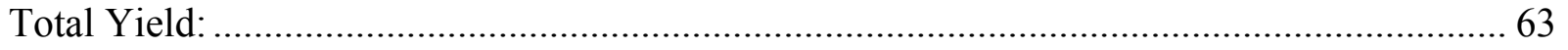

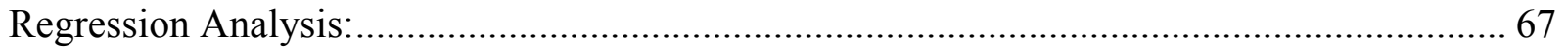

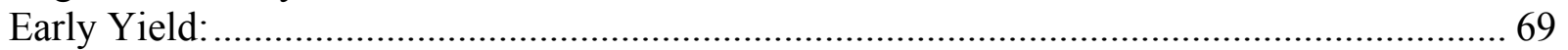

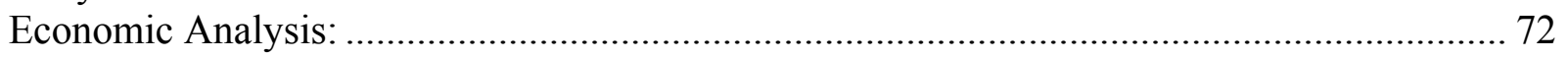

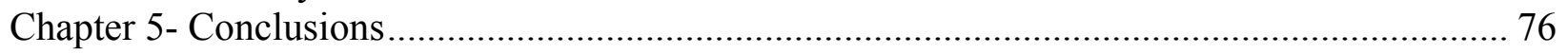

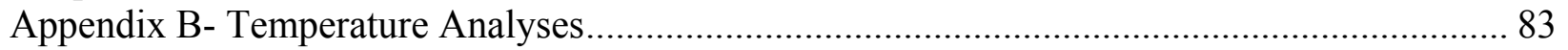

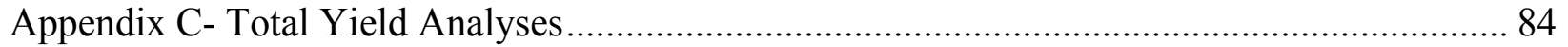

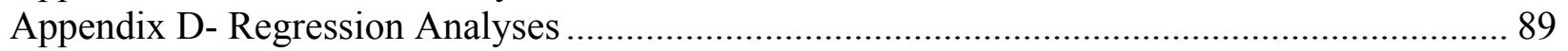

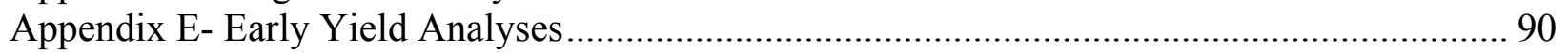

Appendix F- Frost/ Freeze Data.......................................................................................... 91

Appendix G- The Planting Date Determination Model ……..................................................... 92

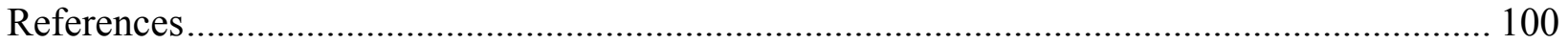




\section{List of Tables}

Table 1 Soil pH and Nutrient Analysis for 2006 and 2007.............................................15

Table 2 Average Air Temperatures for Spring 2006.......................................................26

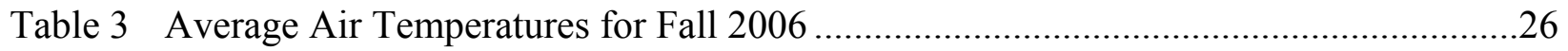

Table 4 Average Air Temperatures for Spring 2007 ..............................................................28

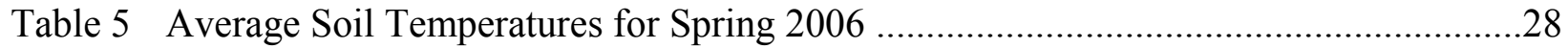

Table 6 Average Soil Temperatures Fall 2006....................................................................30

Table 7 Average Soil Temperatures for Spring 2007.......................................................30

Table 8 Comparison of Photosynthetically Active Radiation in $\mu \mathrm{M} / \mathrm{m}^{2} / \mathrm{sec}$ in the Season

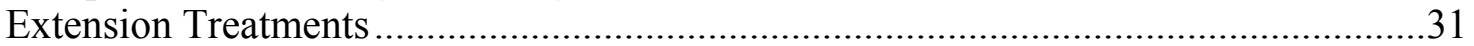

Table 9 Average Total Yield Per Plot for Lettuce-Combined season yields in grams .............33

Table 10 Average Total Yield Per Plot for Radish-Combined season yields in grams. ..............35

Table 11 Average Total Yield Per Plot for Arugula-Combined season yields in grams .............36

Table 12 Average Total Yield Per Plot for Pepper-Combined season yields in grams ..............38

Table 13 Average Total Yield Per Plot for Tomato-Combined season yields in grams ..............40

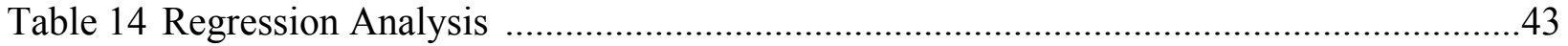

Table 15 Average Early Yield Per Plot for Pepper-Combined spring season yields in grams .....44

Table 16 Average Early Yield Per Plot for Tomato-Combined spring season yields in grams....45

Table 17 Estimated Returns 2006- Average early and regular (after early) season yields for each crop in a $3.7 \times 4.9 \mathrm{~m}$ plot are multiplied by the price per pound

Table 18 Estimated Returns 2007-Average early and regular (after early) season yields for each crop in a $3.7 \times 4.9 \mathrm{~m}$ plot are multiplied by the price per pound ..............................48

Table 19 Additional Costs- The additional costs associated with each treatment plot in excess of labor and material expense incurred for the control................................................49

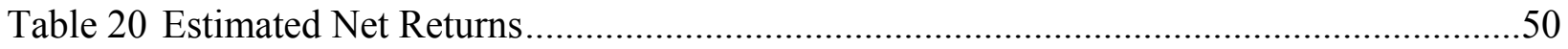




\section{List of Figures}

Figure 1 Average Air Temperatures for Spring 2006 …………………................................51

Figure 2 Average Air Temperatures for Fall 2006 ............................................................. 51

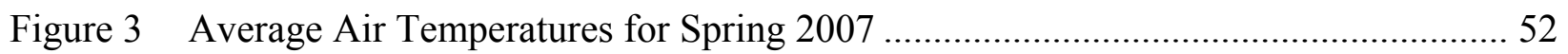

Figure 4 Average Soil Temperatures for Spring 2006 .........................................................52

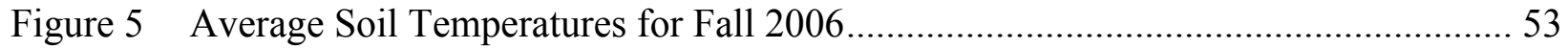

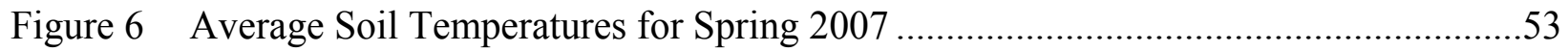

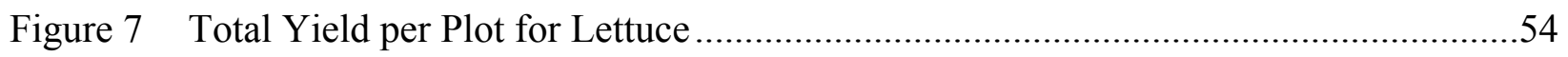

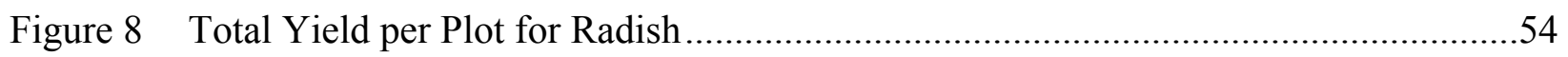

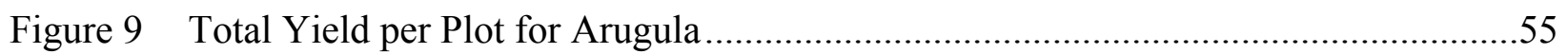

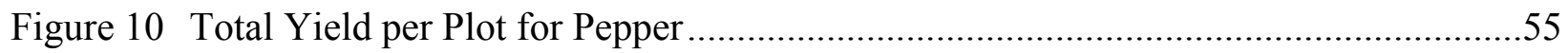

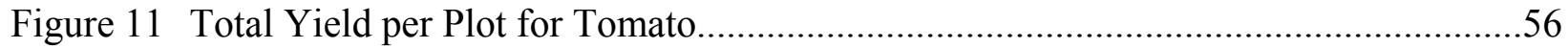

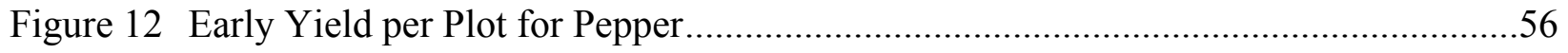

Figure 13 Early Yield per Plot for Tomato …………………............................................. 57 


\section{Chapter 1-Introduction and Literature Review}

Techniques to extend the growing season have been used for centuries by gardeners and growers on all scales in many different climates (Coleman, 1999). Season extension can be accomplished by both earlier spring harvests and later fall crops. Many benefits can be realized, but three broad categories that most interest growers deserve discussion first. The first is quite simply an increase in vegetable production because of an extended growing season. Changes in either plant microclimate or crop and cultivar selection can bring about this lengthening of harvest times. The second main benefit naturally follows the first and is an increase in earnings due to earlier and later cropping. These increased profits are brought about by higher early and late season prices and greater quantities available for market throughout the entire season. The third area of benefits is realized when growers enhance customer loyalty due to an availability of high quality produce for an extended period of time, therefore sustaining their customer base for a larger portion of the year (Bachmann, 2005).

\section{Methods of Season Extension}

Most season extension techniques focus on altering the microclimate around crop plants by raising temperatures in the early spring and late fall for the purpose of prolonging harvest periods. Many techniques can be and are used on a routine basis. One of the simplest and most common ways to extend growing seasons and alter microclimate is site selection (UK, 2007). Planting locations are chosen to maximize the benefits of elevation, slope, aspect, and soil characteristics. Elevation affects both the ambient temperature and movement of air masses, which directly influence both crop survival and productivity. Aspect is an important factor due to its influence on soil temperature and moisture regimes, altered by varying solar radiation for 
different exposures (Bachmann, 2005). The slope, or percent grade, of a planting area influences water and soil movement, and therefore greatly affects overall suitability of cropland. Rain infiltration and soil erosion are very much influenced by the slope of land and can greatly affect soil quality and productivity. Water movement in soil and the rate at which soils drain influence soil temperatures greatly. These differences in drainage and resulting temperatures can affect planting time by several days or weeks (Bachman, 2005). Thus the effect of slope and associated water movement can be very influential in season extension.

Site selection, based on soil characteristics, is likewise used to influence water retention and movement and heat gain in the growing medium. The physical factors of water and heat retention as influenced by soil characteristics also alter microbial, insect, and other biologic activity in soil systems. Therefore, utilizing knowledge of soil types and characteristics in the selection of planting locations can have an impact on both the timing and quality of vegetable production (UK, 2007).

Another season extension technique available for growers is using furrow or sprinkler irrigation systems to extend or preserve cropping seasons. Irrigation methods moderate air temperatures through the high specific heat of water. As water from the sprinkler system is turned into ice, heat is released in the immediate vicinity of sensitive plant tissues. Days can be added to the growing season by saving crops from frost damage in a few sensitive hours (Perry et al., 1991; Selders, 1970). More imaginative approaches have also been examined to protect crops against short-term freezing temperatures. An aqueous foam mixture of water, gelatin, and sucrose has been tested to determine its usefulness in protecting young plants, or blooms from freeze and frost events (Choi et al., 1999). 
Other methods for altering plant microclimates for short and very critical time periods when temperature damage is possible focus on manipulating warm and cold air masses. Temperature inversion effects can be controlled using wind machines to alter crop microclimates by pulling warmer air downward and preventing cold air from settling around plants (Bachmann, 2005).

Windbreaks are also used to reduce temperature losses resulting from windy conditions, thereby allowing warmer air $\left(0.6\right.$ to $1.1^{\circ} \mathrm{C}$ difference $)$ to stay in plant microclimates. The addition of windbreaks or shelterbelts can also control indirect effects of wind, such as plant abrasion and soil erosion. Plant water relations can also be improved and transpiration lowered by reducing wind speed. Overall, modifications of microclimate brought about by controlling wind can increase yields by $5 \%$ to $50 \%$ (Baldwin, 1988). Windbreaks can take the form of wooden fences, and vegetation, such as trees or dense grasses (Hodges and Brandle, 1996; Wittwer and Castilla, 1995). The effects of a permanent tree shelterbelt were studied in muskmelon production and more rapid maturation of fruits was seen in addition to increased leaf area and dry-matter accumulation. Plants in the sheltered areas set flowers two days earlier, set fruit six days earlier, and matured five to six days earlier than those in unsheltered areas. This earlier maturation was related to the lower wind speed, greater accumulation of heat units and higher soil temperatures (Zhang et al., 1999).

While focus is usually placed on raising temperatures, lowering summer temperatures can also increase season length. Shade, applied by using shade cloths similarly to row covers, allows for earlier fall or later spring harvest of cooler season crops sensitive to high summer temperatures and solar radiation (Bachmann, 2005; Kelly, 2005). 
Crop and cultivar selection also play key roles in season extension and production for vegetable growers. Choosing the most adapted variety can increase hardiness and yield. Research on the best cultivars can be found by consulting Cooperative Extension, trade publications, and seed suppliers. Appropriate plant variety selection allows growers to produce a quality crop while adjusting the timing of the crop to meet local demands (Bachman, 2005).

The techniques discussed above can and should play a part in a well-designed vegetable production schedule. However, more recent advances focus on the use of synthetic materials, such as polyethylene and spun-bonded plastics, for more controlled, predictable growing season extension (Lamont, 1996). These techniques are collectively known as plasticulture. They include the use of plastic mulches, row covers, low tunnels, high tunnels, and plastic drip irrigation line (Lamont, 2005).

Earlier, later, and higher yields that can be attained by these season extension technologies have been previously discussed. However, many secondary benefits can be gained from more intensive season extension techniques. Cleaner and higher quality fruit can be raised using mulching systems and the physical protection they provide (Lamont, 1996). Water and fertilizer can be used more efficiently with drip irrigation systems in both conventional and organic systems. Soil benefits can also be realized by the protection of soil surfaces covered with non-synthetic or plastic mulches. Insects, weeds, and diseases can be better controlled by the exclusion and more targeted control of pests in plasticulture systems (Lamont, 2005).

Non-synthetic mulches have been used for many years to increase production by raising soil moisture and moderating temperature. Mulches also control weed growth by preventing germination. Low tunnels and row covers depend greatly on mulches to control weed growth. 
Current conventional production systems use plastic mulches because of the ease of management and precise control they allow when watering and fertilizing crops (Lamont, 1996).

Plastic mulches are used to alter plant microclimates. Soils protected by synthetic mulches are able to retain solar radiation better than unmulched ground. This enhanced utilization of solar energy raises soil temperatures. These increased temperatures have important biological and environmental effects that aid in plant growth. Greater plant productivity and earlier harvests can result from these increases in soil temperatures (Tarara, 2000).

The influence of mulch color has been researched both for its positive and negative effects on plant growth. Cucumbers were grown under black plastic to determine if temperature increases were detrimental to productivity in late summer. The cucumbers were not significantly affected by the higher temperatures found under black mulches, and yields were generally the same as under white mulch. This allowed the cucumbers to be profitably grown as a second crop after tomatoes using the same plastic mulch (Hanna, 2000).

Mulches of many different colors, including black, white, clear, yellow, blue, orange, red, and reflective have been used in vegetable growing systems. Some mulch color studies have shown differences in the level of insects observed on the plants and the subsequent levels of disease incidence in these plants. Season extension can be achieved using these methods by the delayed disease onset as a result of decreased insect populations (Csizinszky et al., 1995).

Research on plastic mulch has become prevalent in recent years while non-synthetic mulching alternatives have been explored less often. The available research on non-synthetic mulches focuses on the use of a vetch fall cover crop that is mown in the spring and left on the soil surface. Several studies have been carried out to compare these vetch mulching systems with conventional plastic mulch systems in both processing and fresh market tomatoes and snap 
beans. In all of these studies, the vetch mulch resulted in equal or greater yields than the plastic mulches. Nitrogen additions by the legume and the addition of organic matter by plant breakdown were determined to be the main factors increasing yield in the non-synthetic mulching systems. (Abdul-Baki and Stommel, 1996; Teasdale and Abdul-Baki, 1995; 1997; 2002).

Other studies have focused on increasing soil temperature and more rapid emergence of direct seeded crops using different mulching techniques (Teasdale, 1995). Short day onions showed higher marketable yields when grown under plastic mulch as compared to bare soil. The increase in net returns for growers was estimated at $\$ 50 /$ ha when plastic mulch was used. This increase was due to increased weights and bulb sizes under mulch (Varina and Roka, 2000). Mulches can also be applied with floating row covers, low tunnels, and water-filled tubes.

Row covers have been used in many applications involving both fruit and vegetable production. This research has mostly focused on changes in temperature and yields. Poling et al. (1991) reported that floating row covers could increase air temperatures by 1 to $2{ }^{\circ} \mathrm{C}$ during the early growing season for strawberries planted in plastic mulch. Strawberry yields were also increased by the use of a row cover during the two weeks in the fall critical to flower development. These differences were attributed to higher temperatures under the row covers (Fernandez, 2001).

Row covers have been shown to be useful in many climates and for a number of crops. Sweet potato production in the southern U.S. can be aided by the use of row covers in transplant production. Spun-bonded row covers can raise temperatures sufficiently in growing areas while avoiding tip burn and heat damage often seen under polyethylene (Dangler, 1994). Even in colder climates of northwestern U.S., floating row covers have been shown to increase the early 
and total yields of cool season crops such as broccoli (Westcott et al., 1991). Spun-bonded row covers have also been shown to increase watermelon yields by increasing earliness and transplant survival (Marr et al., 1991). Other beneficial effects, such as reduced virus incidence, have been observed with row cover use in bell pepper production. The decrease in virus incidence was attributed primarily to preventing access of insect vectors to the crops by the row covers (Avilla et al., 1997). In watermelons, Walters (2003) used row covers to prevent the insect vector from feeding on plant tissues. The effect of the covers, used in conjunction with plastic mulches, was a decrease in the levels of watermelon mosaic virus in the crop.

Tomato early season yields were increased when mulches and row covers were used in conjunction. Polyethylene low tunnels and spun-bonded floating row covers produced higher yields over bare ground treatments. The most pronounced differences were seen in early yields where covers increased harvests by up to $90 \%$ (Reiners and Nitzsche, 1993). The type of covering applied over the mulch affected dates of first flower and first fruit in tomatoes. Slitted polyethylene covers were shown to increase both early blooms and early fruits (Pierce and Crispi, 1989). The authors postulated that warm season crops, such as tomatoes, showed increased yields due to earlier flowering and not because of an increase in fruit number or size (Peterson and Taber, 1991).

Both early and total yields were increased in watermelon and muskmelon production systems when mulches and row covers were combined (Jenni et al., 1998; Soltaini et al., 1995). Experiments with Chinese cabbage also showed the beneficial effects on yield of using row covers and low tunnels. Both row covers and low tunnels increased air and soil temperatures when compared to the control treatments (Moreno et al., 2002). Mulch and row cover systems have also been tested in the production of sweet corn. While results vary depending on soil type 
and variety, even in these traditional field crops the potential for plasticulture techniques to increase yields and profitability was clear (Aguyoh et al., 1999).

Water has long been used as a buffer to avoid drastic temperature changes. Because of the high levels of energy needed to change the temperature of water, it makes an excellent temperature buffer. For example, the Aztecs used chinampas, planting beds surrounded by water, to introduce more fertile soil and moderate temperatures in crop production (Popper, 2007). Water has also been used for centuries for frost protection of fruit and vegetable crops. Water filled tubes moderated soil and air temperatures in row cover and low tunnel systems. Jenni et al., (1998) showed that the presence of water tubes in the plant growing environment increased melon yields over treatments utilizing row covers and mulches alone. Experiments using water filled tubes to moderate microclimates have also shown that this practice increased $\mathrm{CO}_{2}$ concentrations three to four fold. The high $\mathrm{CO}_{2}$ concentrations primarily occurred in nonperforated low tunnels and was attributed to increased soil respiration caused by higher soil temperatures and restricted air movement (Aziz et al., 2001).

Additional research on the use of water tubes placed inside vented low tunnels showed that temperature fluctuations could be minimized and a more stable growing environment could be maintained (Aziz et al., 2001). However, non-perforated tunnels had the advantage of increasing growth and development early in the season before excessive air temperatures become a threat. Overall, water tubes placed inside the tunnels increased growth and development over those tunnels without water tubes (Aziz et al., 2001).

The use of larger protective structures for horticultural crop production has also emerged in recent years. Many growers around the country are currently using cold frames, now often called high tunnels, in vegetable and small fruit crop production. These unheated, plastic- 
covered metal or wooden structures have been shown to increase season length by one to four weeks (Wells and Loy, 1993). This allows growers to capture early markets and higher prices for their produce (Bachmann, 2005).

There is currently an interesting collection of research emerging on both the design and construction of high tunnels (Lamont et al., 2002) and the feasibility and profitability of crops grown in them (Rader and Karlsson, 2006; Waterer, 2003).

Experiments involving leaf and romaine lettuce showed that high tunnels provide positive effects on temperatures. The changes in microclimate resulted in negligible yield increases throughout the production season, but the increased quality of the lettuce was noted as a key benefit of the high tunnel system (Rader and Karlsson, 2006). Warm season crops, such as tomatoes, peppers, and muskmelon have shown higher productivity and profitability in high tunnels compared to open field production and less intensive low tunnel season extension systems. The seasonal accumulation of growing degree-days was accelerated the use of high tunnels and crops had greater overall fruit yields when compared to row cover and low tunnel systems (Waterer, 2003).

Another important factor that affects season extension is the possibility for more efficient use of sunlight energy. Solar technologies are easily incorporated into some of the growing systems discussed above (Bellows, 2003; McCullagh, 1978). Passive solar greenhouses are a low-cost alternative that can be used to extend the season beyond what is possible with cold frames and high tunnels alone. These gains are made by storing solar radiation as heat, which increases the accumulated heat units in plant growing areas. Important components of solar greenhouses are orientation and appropriate glazing material to allow for maximum sunlight capture and to avoid heat loss. However, the key component in these systems is the dense 
materials, such as water or stone, used to store and later release the heat from solar radiation collected during the day (Bellows, 2003; McCullagh, 1978).

Season extension can also be accomplished by using low-cost heat sources to augment solar temperature gains in protected structures. Some key materials available for this application are compost and various animal manures. Research has been carried out on the use of compost heating for homes and greenhouses (Fulford, 1983).

Greenhouses can be heated by compost to extend the growing season or to allow for yearround crop production. Animal manures, leaves, grass, wood chips, and other composting materials break down and release heat as a by-product of the decomposition process. The practice of composting is complex and much more difficult to control than conventional heating techniques. It is a technique best used to extend the length of growing seasons and management would prove quite challenging for year-round production. Both heat and carbon dioxide produced from the compost have been proven valuable to plant growth, decreasing input costs and raising yields (Fulford, 1983). However, ammonia production and high nitrate levels in leafy greens can be a concern when using compost to heat greenhouse or cold frames (Diver, 2001).

In the 1970's and 1980's, some early research was carried out using compost to heat both homes and greenhouses. However, additional information is currently needed because conclusive research is lacking in these promising areas (Diver, 2001). The use of compost as a fuel for heating greenhouse structures has not been extensively compared to other available season extension methods. There is also a gap in the knowledge of many season extension technologies and their use in organic production. 
The above described season extension techniques, such as row covers, mulches, and cold frames or high tunnels, when used appropriately and in combination can potentially increase the length of cropping seasons and the quality and profitability of the produce grown. Season extending technologies can be used on a variety of crops with most research focusing on warm season vegetables, such as tomatoes and melons, and small fruits, such as strawberries. The effect of these technologies on cool season crops has been much less investigated.

\section{Overview and Goals}

As described above, significant increases in yield and quality have been reported using methods of season extension. Differing combinations of these methods have been investigated, but lower input techniques, such as row covers and low tunnels, and higher input cold frames or high tunnels have rarely been compared in the same study. Inclusion of water tubes in the growing environments has shown some promise, but published data does not address a variety of crops. The influence of water tubes on both air and soil temperatures and the response of specific crops most appropriate for use in these systems need to be better understood.

Along with data on the effectiveness of various season extension methods, assistance for growers is needed in the correct application of season extension methods. The integration of these techniques into a decision making model, an integral part of this project, has not, to our knowledge, been reported. Combining frost/ freeze charts and specific season extension technologies into a decision making model would be a very useful tool for growers in determining planting times and choices of production techniques. This planting date determination model can be found in Appendix G. 
Building on previous research on season extension methods such as mulches, row covers, cold frames, and elements of solar and compost heating; I hope to gain new knowledge that can be easily disseminated to growers. Producers should be able to combine their desired crops with season extending methods to best fit their chosen markets. The season extension methods of row covers, and low tunnels in field plots will be tested along with cold frame growing systems on a variety of vegetable crops. Water tubes or jugs will be used in each of these season extension methods to determine its effect on crop yield and microclimate. The central goal of this research is to allow season extension technologies and planting date decisions to be more easily integrated into vegetable production systems for both organic and conventional growers in the Northeast United States. 


\section{Objectives}

- Compare the effects of season extension methods on air and soil temperatures and total and early leaf, root, or fruit yield

- Determine the effect of the inclusion of water tubes in growing environments on air and soil temperatures and total and early leaf, root, or fruit yield

- Complete an economic analysis to determine the feasibility and profitability of the season extension methods used in this study

- Develop a decision making tool that incorporates local climate data and season extension technologies 


\section{Chapter 2-Materials and Methods}

\section{Location:}

All experiments were carried out at the West Virginia University Plant and Soil Sciences Organic Farm, which has been under certified organic production since 2003. The farm is located on Route 705 in Morgantown, West Virginia. The market garden is located on a bench and all plots have less than $4 \%$ slope, thereby eliminating the possible influence of warmer southern slopes, and cold air drainage. The control and four experimental treatments (see below) were carried out in field plots located in predetermined growing areas (see Appendix A) under cultivation for at least two years adjacent to existing market garden plots. The two cold frame structures used in subsequent experiments were already erected in this area.

The soil type in the growing plots is a moderately well drained silt loam in the Tilsit series. The taxonomic class of this soil is fine-silty, mixed, semiactive, mesic Typic Fragiudults. The parent material is a siltstone or fine-grained sandstone. This Tilsit series has a fragipan occurring around 50 to $64 \mathrm{~cm}$ (20 to 25 inches), but this slowly permeable layer has little effect on the growing environment of the market garden or the research plots especially since the whole area is tiled. Representative soil samples were analyzed for $\mathrm{pH}$ using a diluted sample (Eckert and Sims, 1995), and macro and micronutrient levels $(\mathrm{mg} / \mathrm{kg})$ were determined using the Mehlich 1 extraction method (Wolf and Beegle, 1995). 
Table 1: Soil pH and Nutrient Analysis for 2006 and 2007

\begin{tabular}{c|crrrrrrrr} 
2006 & $\mathbf{p H}$ & \multicolumn{1}{c}{$\mathbf{P}$} & \multicolumn{1}{c}{$\mathbf{K}$} & \multicolumn{1}{c}{$\mathbf{N a}$} & \multicolumn{1}{|c}{$\mathbf{Z n}$} & \multicolumn{1}{c}{$\mathbf{M n}$} & $\mathbf{C u}$ & $\mathbf{M g}$ & $\mathbf{C a}$ \\
\hline Depth & & $\mathrm{mg} / \mathrm{kg}$ & $\mathrm{mg} / \mathrm{kg}$ & $\mathrm{mg} / \mathrm{kg}$ & $\mathrm{mg} / \mathrm{kg}$ & $\mathrm{mg} / \mathrm{kg}$ & $\mathrm{mg} / \mathrm{kg}$ & $\mathrm{mg} / \mathrm{kg}$ & $\mathrm{mg} / \mathrm{kg}$ \\
$\mathbf{0 - 3}$ in & 6.53 & 9.15 & 53.9 & 15.06 & 1.48 & 16.81 & 0.17 & 32.20 & 408.73 \\
$\mathbf{3 - 6}$ in & 6.39 & 8.02 & 36.10 & 15.14 & 1.49 & 17.42 & 0.22 & 30.46 & 369.4 \\
$\mathbf{6 - 1 2}$ in & 6.07 & 5.06 & 25.69 & 14.9 & 1.00 & 18.03 & 0.23 & 25.64 & 287.66 \\
& & & & & & & & & \\
$\mathbf{2 0 0 7}$ & $\mathbf{p H}$ & $\mathbf{P}$ & $\mathbf{K}$ & $\mathbf{N a}$ & $\mathbf{Z n}$ & $\mathbf{M n}$ & $\mathbf{C u}$ & $\mathbf{M g}$ & $\mathbf{C a}$ \\
$\mathbf{D e p t h}$ & & $\mathrm{mg} / \mathrm{kg}$ & $\mathrm{mg} / \mathrm{kg}$ & $\mathrm{mg} / \mathrm{kg}$ & $\mathrm{mg} / \mathrm{kg}$ & $\mathrm{mg} / \mathrm{kg}$ & $\mathrm{mg} / \mathrm{kg}$ & $\mathrm{mg} / \mathrm{kg}$ & $\mathrm{mg} / \mathrm{kg}$ \\
$\mathbf{0 - 3}$ in & 6.84 & 12.02 & 37.12 & 13.06 & 1.67 & 16.56 & 0.13 & 32.69 & 460.26 \\
$\mathbf{3 - 6}$ in & 6.72 & 4.91 & 24.28 & 14.20 & 1.06 & 17.16 & 0.20 & 25.55 & 318.76 \\
$\mathbf{6 - 1 2}$ in & 6.72 & 2.49 & 15.50 & 13.50 & 0.77 & 13.57 & 0.24 & 21.14 & 269.20
\end{tabular}




\section{Plant Material:}

The plant material used in these experiments was grown under organic rule specifications for the entirety of the project (USDA, 2002). Organic seed was obtained from Johnny's Selected Seeds (Winslow, ME) and High Mowing Seeds (Wolcott, VT). The tomato seeds used in this experiment were collected from the WVU Organic Research Farm after the previous growing season. Warm season crops were: tomato (WV '63), and bell pepper (Orion). Cool season crops were: romaine lettuce (Parris Island), radishes (Easter Egg, Pink Beauty), and arugula (Astro). Spinach was used as a cool season crop in the 2006 spring and fall seasons, but because of fungal pathogens present in the market garden soil, yields were not measurable for this experiment. Arugula was used in the place of spinach as a cool season green in the 2007 season.

Tomato, pepper, and lettuce plants were seeded in the West Virginia University Plant and Soil Sciences greenhouse while the radish and arugula crops were sown directly in the plots. Tomato, pepper, and lettuce transplants were started in the in greenhouse in a portion of the mist bed designated for organic production. After being transplanted into cell packs, the transplants were moved to a certified organic room for four weeks. The medium used for these transplants consisted of two parts composted cow manure, one part peat moss, and one part perlite. Clear water was used on all transplants while in the greenhouse and over the course of the entire experiment.

\section{Season Extension Treatments:}

Six season extension treatments, (1) row cover, (2) row cover with water tubes, (3) low tunnel, (4) low tunnel with water tubes, (5) cold frame, (6) cold frame with water wall and a control were compared in the spring and fall 2006 and spring 2007 growing seasons. The two 
cold frame treatments $(5,6)$ were carried out in separate structures adjacent to the market garden site, which contained one plot because of space restrictions. The other four treatments (1-4) and the control were each replicated three times in a randomized complete block design in an adjacent cultivated area (referred to as field plots). These 15 plots were randomized separately for the 2006 and 2007 years (see Appendix A). The dimensions of the plots were $3.7 \mathrm{~m} \mathrm{x} 4.9 \mathrm{~m}$ with a total area of $18 \mathrm{~m}^{2}$ per plot. Planting areas in each plot were divided equally between warm and cool season crops. The warm season crops were planted in two $4.9 \mathrm{~m}$ rows with one row for peppers (eight plants) and one row for tomatoes (six plants). The cool season crops were planted in two rows with approximately three meters of row length for lettuce, radish, and arugula or spinach.

Irrigation was provided as needed throughout the season. Drip irrigation line was installed in field plots to provide equal watering for all plots. Transplanted crops with longer growing seasons, such as tomatoes and peppers, were mulched with newspapers and hay. Mulch was applied to aid in weed control, moderate soil temperature, and enhance soil water retention. Lettuce, arugula, and radish crops were planted or seeded directly in the soil without the use of mulch due to their closer spacing and shorter growing seasons. The control and all treatments were fertilized by adding composted dairy manure (WVU Animal Sciences Farm) at a rate of 55 $\mathrm{kg} / \mathrm{plot}$ prior to planting in both the spring 2006 and 2007 seasons.

The row covers and low tunnels were installed at the time of planting for both the warm and cool season crops in the spring 2006 and 2007 seasons. They were in place until excessive temperatures ( 32 to $35^{\circ} \mathrm{C}$, Decoteau, 2000) occurred around June $10^{\text {th }}$ for the warm season crops in both 2006 and 2007. The row covers and low tunnels were left in place until harvest for spring cool season crops in all treatments. In the fall 2006 season, row covers and low tunnels 
were installed on September $17^{\text {th }}$ and left in place until the final harvest for both the warm and cool season crops.

The control and all experimental treatments were planted according to predicted dates of last and first frost and the minimum temperature protection provided by each season extension method as described in the planting date determination model (Appendix G). The crops in this study were planted using the following assumptions of temperature increases as the experimentally derived levels of temperature increases described in Appendix G were obtained during the course of this experiment. The row cover and low tunnel treatments, in addition to the cold frame without water jugs were assumed to provide $2.2^{\circ} \mathrm{C}\left(4^{\circ} \mathrm{F}\right)$ temperature protection. These temperature protection estimates were taken from manufacturer (see treatments 1 and 3 below) recommendations. The cold frame with the water wall and compost was assumed to provide $4.4^{\circ} \mathrm{C}\left(8^{\circ} \mathrm{F}\right)$ minimum temperature increase due to anticipated gains from the water wall and composting system.

Yearly conditions influenced planting dates to some degree. In the spring of 2006, cool season crops were planted on 3/10 (treatment 6), 3/31 (1-5), and 4/17 (control) while warm season crops were planted on 4/14 (6), 5/4 (1-5), and 5/19 (control). In the spring of 2007, cool season crops were planted on 3/28 (6), 4/9 (1-5), and 4/30 (control) while warm season crops were planted on 4/24 (6), 5/9 (1-5), and 5/27 (control). Fall 2006 cool season crops were planted on $8 / 20$ (control), $8 / 30$ (1-5), and 9/10 (6) and warm season crops were all planted on 8/1.

\section{Control:}

No season extension techniques were applied. 


\section{Treatment 1:}

The first treatment was a spun-bonded polypropylene row cover placed over the plants and supported with ten-gauge wire to prevent plant damage because of abrasion by the fabric under windy conditions. A medium weight row cover was used in this treatment (Agribon+ 19, $17.06 \mathrm{~g} / \mathrm{m}$ or $0.55 \mathrm{oz} / \mathrm{yd}$, Johnny's Selected Seeds, Wolcott, VT). Row cover edges were covered with soil on all sides to maintain plant microclimate and prevent wind disturbances.

\section{Treatment 2:}

The second treatment used water-filled plastic tubes made of 6-mil clear polyethylene 15 $\mathrm{cm}$ in diameter (U-Line Shipping Supply, Chicago, IL) placed under the row covers described in treatment 1 . These tubes were cut in $1 \mathrm{~m}$ to $1.5 \mathrm{~m}$ lengths, filled approximately three-fourths full with water, heat sealed on the ends, and placed on the mulch or bare soil under the row cover on both side of each planted row. Each plot contained approximately 30 meters of these water-filled polyethylene tubes (see Appendix A).

\section{Treatment 3:}

The third treatment was a low tunnel, consisting of a commercially available (Hummert's Horticultural Supply, Earth City, MO) 0.5-mil polyethylene stretched across ten-gauge wire hoops approximately $1.8 \mathrm{~m}$ apart, $45 \mathrm{~cm}$ off the ground and of $1 \mathrm{~m}$ width completely covering the row. The plastic was slitted approximately every $\mathrm{cm}$ for $20 \mathrm{~m}$ on both sides of the tunnel allowing air exchange to prevent excessive mid-day temperatures while maintaining slightly elevated temperatures and raising (plant) accumulated heat units. The polyethylene was held down on the edges with soil as described for the row covers. 


\section{Treatment 4:}

The fourth treatment used the low tunnel method as described for treatment 3 with the addition of the water-filled tubes described in treatment 2.

\section{Treatment 5:}

The fifth treatment was one of the previously constructed cold frames near the market garden site. The Quonset style cold frames were $6 \mathrm{~m}$ wide by $7.6 \mathrm{~m}$ long and covered with a single layer of 6-mil polyethylene. End walls were non-moveable and two doors were placed on each end. Sidewall plastic was secured to the baseboards and ventilation occurred through the doors on the end walls. A single plot occupied $18 \mathrm{~m}^{2}$ of the overall enclosed area $\left(45 \mathrm{~m}^{2}\right)$. Treatment 6:

The sixth and final treatment was the other $6 \mathrm{~m}$ by $7.6 \mathrm{~m}$ cold frame. The southern half of the cold frame was used for crops, and again consisted of one $18 \mathrm{~m}^{2}$ plot. A water wall was constructed in the center of this cold frame using 4"x 6" posts with 2"x 6" board shelving to hold approximately 300 water-filled plastic gallon milk jugs stacked ground to ceiling to moderate temperatures (see Appendix A).

On the north side of the cold frame two $4.5 \mathrm{~m}^{3}$ compost piles were constructed. Raw compost composed of dairy manure, bedding, and wood chips was secured from the WVU Animal Sciences Farm. The two compost piles were each $2 \mathrm{~m}$ x $2 \mathrm{~m}$ wide and approximately $1.13 \mathrm{~m}$ feet in height. Both static piles were aerated with a forced air system. $10 \mathrm{~cm}$ perforated plastic pipe in the bottom and center of the piles was attached to a squirrel cage blower (model 2C647 134 CFM, Grainger Industrial Supply, Morgantown, WV) and a single stage thermostat set to operate when temperatures in the center of the pile reached $48^{\circ} \mathrm{C}$. Air was pumped by the blower through the piles to cool them and provide oxygen to fuel the composting process. The 
excess heat and carbon dioxide produced by the compost piles was intended to passively heat the southern growing side of the cold frame after passing through a hay wall to remove unwanted $\mathrm{NH}_{3}$. The hay wall was built ground to ceiling with square hay bales alongside the water wall on the northern composting side of the cold frame (see Appendix A). Compost was used in this system for the spring and fall season of 2006, but was not available for the 2007 spring season.

\section{Data Collection:}

Temperature data was collected in one plot of each treatment and the control. Light measurements were gathered continuously on a control plot and measurements were taken in two-week intervals for comparison in the experimental treatment plots. Yield data was gathered on all replicates of each treatment for each crop.

Temperature:

A Spectrum model 125 data logger (Spectrum Technologies, East Plainfield, IL) gathered air and soil temperatures. The loggers used for air temperature were placed at ground level in white plastic tubing in the center of covered rows to prevent weather damage and maintain accurate readings regardless of solar radiation. Soil temperatures were gathered using thermocouples placed $10 \mathrm{~cm}$ below the surface connected to the same data logger. These hourly air and soil temperatures were then averaged to obtain a daily and overall treatment temperature average.

Light:

Light levels measured in $\mu \mathrm{M} / \mathrm{m}^{2} / \mathrm{sec}$ reaching the plants were measured with Spectrum quantum light sensor as an attachment to a Spectrum model 225 or model 425 data logger. This light sensor measured light in the 400 to $700 \mathrm{~nm}$ range also known as photosynthetically active radiation $(\mathrm{PAR})$. 
One light sensor was located permanently in a control field plot to obtain a control light level. Another light sensor was moved from treatment to treatment to gather light data for comparison with control levels. Sensors were placed $0.3 \mathrm{~m}$ above the soil level. Light readings were taken in two-week intervals in the row covers, low tunnels, and cold frame treatments. Daytime hourly readings were averaged. Daily averages were then averaged for two-week periods and treatment PAR averages were compared to control PAR levels. Total Yield:

Cool season crop leaves and roots were harvested in a single destructive harvest. The plants were then weighed and weights recorded in grams. Mature fruit was harvested weekly from the warm season crops. Total yield data in grams was gathered on all plots in all treatments for each season. Total yield data was calculated separately for each crop in each plot. Early Yield:

Early yield was the total weights in grams of all harvests from each crop in each plot that reached a mature, harvestable stage before the first harvest from the control plots. Since the cool season crops were all harvested before the control plots, all yields for these crops could be considered early. The period of time considered as early varied in relation to each cropping season for the warm season tomatoes and peppers.

Economic Analysis:

To carry out the economic analysis, additional labor and material inputs were calculated and compared with production totals to determine a cost benefit measurement for each of the six experimental treatments. Returns for treatments were calculated for each crop in each treatment by using the prevailing price at the Morgantown farmers market where this produce was sold. Our economic analysis assumed that all produce could be sold. The cost of additional inputs and 
labor were calculated according to the purchase price and the useful life of the equipment and supplies used in our season extension experiments. These costs were calculated on a plot (18 $\mathrm{m}^{2}$ ) basis. The cost of all needed material inputs was calculated using current market prices. Low tunnels and water tubes were assumed to be used only once, row covers and wires were assigned a three-year life span, and the cold frame structures were assumed to have a functional life span of ten years. Labor and maintenance were also added to the overall costs of all the treatments. The costs in excess of control expenses for each treatment were then calculated to determine additional costs of each treatment. A net profit or loss was calculated by subtracting the additional costs from the expected profit for each experimental treatment.

\section{Experimental Set-Up:}

The first four treatments and the control were laid out in three blocks each containing one replicate of each treatment. In these blocks, the specific location of the treatment replicate was randomized each year. The two treatments involving the cold frames were not replicated. The variances determined from the other five treatments were used to statistically analyze the data from the cold frames upon consultation with a statistician (Dr. Seidel, Dr. Wearden, personal communication).

\section{Statistics:}

The General Linear Model was used to analyze both the temperature and yield data in this study. The average daily air and soil temperatures from each treatment in the spring 2006, fall 2006 and spring 2007 were averaged for an average treatment temperature for each season. An analysis of variance using SAS software was carried out and least significant differences were determined to allow the average temperatures to be compared (Appendix B). Additionally, 
a contrast was performed to determine if the control average was significantly lower than the treatment averages.

A GLM to fit an ANOVA for a randomized complete block design was used to determine if total yield differences existed among the treatments (Appendix C). The four field plot treatments and the control (15 plots in total) were analyzed together using JMP software. This analysis was also used to create confidence intervals to determine if the two cold frame treatments were different from the five field plots (Appendix C). This was necessary because the field plot treatments each had three replicates while the cold frame treatments had only one replicate. Orthogonal contrasts and effect tests were performed on the total yield data from the field plots to further determine sources of differences. Contrasts were carried out on control vs. others, water tubes vs. without water tubes, and row covers vs. low tunnels (Appendix C).

A simple linear regression was also conducted (SAS) for the total yield data and the air and soil temperatures for the spring and fall 2006 and spring 2007 seasons. Treatment temperature averages were used to determine the relationship between temperature and total yield for the five crops in our study. The strength of these relationships is reported with $\mathrm{R}^{2}$ values and corresponding $\mathrm{P}$ values (Appendix D). The results are divided into effects for the spring seasons (06/07) and the effects on the fall season (2006 only) for both air and soil temperatures.

A GLM to fit an ANOVA was carried out using JMP software to determine if early yield differences existed among the treatments (Appendix E). Early yield was analyzed for the more reliable spring seasons of 2006 and 2007. Contrasts on water tubes vs. no water tubes were carried out the see if differences existed. 


\section{Chapter 3- Results}

\section{Temperature:}

In the spring 2006 growing season, the effect of treatments on air temperature (Figure 1) was significant $(\mathrm{P}=<0.0001)$ (Appendix $\mathrm{B})$. The highest average air temperature (Table 2) was recorded in the cold frame with water $\left(19.6^{\circ} \mathrm{C}\right)$, which was higher than the control, row cover, low tunnel and low tunnel with water treatments. The cold frame temperature $\left(18.5^{\circ} \mathrm{C}\right)$ and the temperatures in the row cover treatments $\left(18.1^{\circ} \mathrm{C}, 18.4^{\circ} \mathrm{C}\right)$ were similar. Both the cold frame and the row cover with water tubes recorded higher temperatures than were observed in the low tunnel treatments $\left(16.7^{\circ} \mathrm{C}, 16.6^{\circ} \mathrm{C}\right)$. All experimental treatment temperatures were higher than the control $\left(15.0^{\circ} \mathrm{C}\right)$. The control temperature was significantly lower than the other six treatments $(<0.0001)$ in the control vs. others contrast. The temperature in the row cover with water and low tunnel with water treatments was not different than the temperature in the row cover and low tunnel without water tubes treatments.

Air temperatures in the fall 2006 growing season (Table 3) showed an effect (0.0043) of treatments (Figure 2). The cold frame $\left(17.0^{\circ} \mathrm{C}\right)$ and cold frame with water $\left(17.0^{\circ} \mathrm{C}\right)$ treatments recorded higher temperatures than the control $\left(13.7^{\circ} \mathrm{C}\right)$ and low tunnel treatments $\left(14.5^{\circ} \mathrm{C}\right.$, $\left.14.9^{\circ} \mathrm{C}\right)$. The row cover $\left(15.5^{\circ} \mathrm{C}\right)$ treatment was similar to all other treatments and the control, while the row cover with water $\left(15.8^{\circ} \mathrm{C}\right)$ treatment was higher than the control and similar to the low tunnel treatments. The contrast of control vs. others showed that the temperature observed for the control was significantly lower than the other treatments $(0.0051)$. Significantly higher temperature averages were not seen in the treatments with water tubes when compared to the treatments without water tubes. 
Table 2: Average Air Temperatures for the Spring 2006 Season (4/2- 6/13)

Each treatment average represents the average temperatures throughout the season. SE is the standard error of the mean ( $\mathrm{N}=73$ days). Letters denote differences between treatments.

Treatments with the same letter are not significantly different from each other.

\begin{tabular}{cccc}
\hline & Differences (0.05) & ${ }^{\circ}$ C Average & SE \\
\hline Control & $\mathrm{A}$ & 15.0 & 0.5 \\
Row Cover & $\mathrm{CD}$ & 18.1 & 0.5 \\
Row Cover with Water & $\mathrm{DE}$ & 18.4 & 0.5 \\
Low Tunnel & $\mathrm{BC}$ & 16.7 & 0.6 \\
Low Tunnel with Water & $\mathrm{B}$ & 16.6 & 0.5 \\
$\quad$ Cold Frame & $\mathrm{DE}$ & 18.5 & 0.5 \\
Cold Frame with Water & $\mathrm{E}$ & 19.6 & 0.4 \\
$\quad$ ANOVA & & $* * *$ & \\
$\quad \begin{array}{c}\text { Contrast } \\
\text { Control vs. Others }\end{array}$ & & $* * *$ & \\
\hline
\end{tabular}

$\mathrm{NS}, *, * *, * * *$ Nonsignificant or significant at $\mathrm{P}=0.05,0.01,0.001$, respectively

Table 3: Average Air Temperatures for the Fall 2006 Season (9/19-10/22)

Each treatment average represents the average temperatures throughout the season. SE is the standard error of the mean ( $\mathrm{N}=34$ days). Letters denote differences between treatments.

Treatments with the same letter are not significantly different from each other.

\begin{tabular}{cccc}
\hline & Differences $(\mathbf{0 . 0 5})$ & ${ }^{\circ}$ C Average & SE \\
\hline Control & $\mathrm{A}$ & 13.7 & 0.7 \\
Row Cover & $\mathrm{ABC}$ & 15.5 & 0.7 \\
Row Cover with Water & $\mathrm{BC}$ & 15.8 & 0.7 \\
Low Tunnel & $\mathrm{AB}$ & 14.5 & 0.7 \\
Low Tunnel with Water & $\mathrm{AB}$ & 14.9 & 0.7 \\
Cold Frame & $\mathrm{C}$ & 17.0 & 0.6 \\
Cold Frame with Water & $\mathrm{C}$ & 17.0 & 0.5 \\
ANOVA & & $* *$ & \\
Contrast & & $* *$ & \\
Control vs. Others & & & \\
\hline
\end{tabular}

$\mathrm{NS}, *, * * * * *$ Nonsignificant or significant at $\mathrm{P}=0.05,0.01,0.001$, respectively 
Air temperature averages in the spring 2007 growing season (Table 4) displayed fewer differences (0.10) than the 2006 spring season (Figure 3) among all treatments. However, like the spring 2006 and fall 2006 air temperature analyses, the control vs. other contrast showed a significant difference (0.014). The highest temperatures were registered in the two cold frame treatments $\left(20.0^{\circ} \mathrm{C}, 19.4^{\circ} \mathrm{C}\right)$. The temperatures of the row cover treatments $\left(18.7^{\circ} \mathrm{C}, 19.2^{\circ} \mathrm{C}\right)$ and the low tunnel with water treatment temperatures $\left(18.8^{\circ} \mathrm{C}\right)$ were similar to the cold frame temperature averages. The temperatures observed in the cold frame treatments and the row cover with water treatment were all higher than the control $\left(16.9^{\circ} \mathrm{C}\right)$ treatment. The row cover and low tunnel with water tubes treatments did not show significantly higher air temperatures when compared to those same treatments without water tubes. The average air temperatures of all three seasons combined showed that there is no effect of season upon treatment (0.99) air temperatures.

In the soil temperature averages from spring 2006 (Table 5), treatment effects $(<0.0001)$ were observed (Figure 4). Least significant differences tests showed that the temperatures in the cold frame $\left(18.6^{\circ} \mathrm{C}\right)$ and cold frame with water $\left(19.1^{\circ} \mathrm{C}\right)$ treatments were similar and higher than all the field plot treatments and the control. The row cover $\left(16.3^{\circ} \mathrm{C}\right)$ and row cover with water tube $\left(16.7^{\circ} \mathrm{C}\right)$ treatments were similar to the low tunnel with water treatment temperature $\left(16.1^{\circ} \mathrm{C}\right)$. However, the row cover with water tube treatment was higher than the low tunnel treatment $\left(15.3^{\circ} \mathrm{C}\right)$. Row cover and low tunnel with water tube treatments did not show temperature increases over corresponding treatments without the addition of water tubes. The contrast of control vs. other treatments resulted in a highly significant effect with a P value of $<0.0001$. 
Table 4: Average Air Temperatures for the Spring 2007 Season (4/10 -6/11)

Each treatment average represents the average temperatures throughout the season. SE is the standard error of the mean $(\mathrm{N}=63$ days). Letters denote differences between treatments. Treatments with the same letter are not significantly different from each other.

\begin{tabular}{cccc}
\hline & Differences $(\mathbf{0 . 0 5})$ & ${ }^{\circ}$ C Average & SE \\
\hline Control & $\mathrm{A}$ & 16.9 & 0.7 \\
Row Cover & $\mathrm{ABC}$ & 18.7 & 0.8 \\
Row Cover with Water & $\mathrm{BC}$ & 19.2 & 0.8 \\
Low Tunnel & $\mathrm{AB}$ & 17.8 & 0.8 \\
Low Tunnel with Water & $\mathrm{ABC}$ & 18.8 & 0.8 \\
Cold Frame & $\mathrm{C}$ & 20.0 & 0.7 \\
Cold Frame with Water & $\mathrm{BC}$ & 19.4 & 0.7 \\
ANOVA & & $\mathrm{NS}(0.10)$ & \\
$\quad$ Contrast & & $*$ & \\
Control vs. Others & & & \\
\hline
\end{tabular}

NS, $*, * *, * *$ Nonsignificant or significant at $\mathrm{P}=0.05,0.01,0.001$, respectively

Table 5: Average Soil Temperatures for the Spring 2006 Season (4/2- 6/13)

Each treatment average represents the average temperatures throughout the season. SE is the standard error of the mean ( $\mathrm{N}=73$ days). Letters denote differences between treatments. Treatments with the same letter are not significantly different from each other.

\begin{tabular}{cccc}
\hline & Differences (0.05) & ${ }^{\circ}$ C Average & SE \\
\hline Control & A & 15.4 & 0.4 \\
Row Cover & AB & 16.3 & 0.4 \\
Row Cover with Water & $\mathrm{B}$ & 16.7 & 0.3 \\
Low Tunnel & $\mathrm{A}$ & 15.3 & 0.4 \\
Low Tunnel with Water & $\mathrm{AB}$ & 16.1 & 0.4 \\
Cold Frame & $\mathrm{C}$ & 18.6 & 0.3 \\
Cold Frame with Water & $\mathrm{C}$ & 19.1 & 0.3 \\
ANOVA & & $* * *$ & \\
$\quad$ Contrast & & $* * *$ & \\
Control vs. Others & & & \\
\hline
\end{tabular}

$\mathrm{NS}, *, * *, * * *$ Nonsignificant or significant at $\mathrm{P}=0.05,0.01,0.001$, respectively 
For soil temperatures averages in the fall 2006 season (Figure 5), treatment effects on temperature were observed $(<0.0001)$. The cold frame $\left(18.9^{\circ} \mathrm{C}\right)$ and cold frame with water $\left(18.5^{\circ} \mathrm{C}\right)$ treatments showed the highest soil temperature averages in the fall of 2006 out of all treatments (Table 6$)$. The row cover $\left(16.7^{\circ} \mathrm{C}\right)$ and row cover with water $\left(16.7^{\circ} \mathrm{C}\right)$ treatment temperatures were higher than the control temperature $\left(15.3^{\circ} \mathrm{C}\right)$. The low tunnel $\left(16.5^{\circ} \mathrm{C}\right)$ and low tunnel with water $\left(16.6^{\circ} \mathrm{C}\right)$ treatment temperatures were similar to the control average soil temperature. No differences in temperature between the row cover and low tunnel treatments and between treatments with water tubes and without water tubes were observed. The control treatment vs. other treatments contrast was again significant $(<0.0001)$.

An ANOVA (GLM model) was performed on all existing soil temperature data for the spring 2007 season (0.001). The results of the least significant differences test can be found in Table 7 (column 2). Missing data from the control plot from $4 / 10$ through $5 / 1$ resulted in control temperature averages higher than the soil temperatures observed in the field plot treatments and similar to the temperature averages recorded in the cold frame treatments.

The average soil temperature differences in the spring 2007 season excluding the control (Table 7, column 5 and Figure 6) for the period 4/1 through 6/11 are clearer in detailing the effect $(\mathrm{P}=0.042)$ of the treatments. The average temperatures in the cold frame $\left(18.6^{\circ} \mathrm{C}\right)$ and cold frame with water $\left(18.5^{\circ} \mathrm{C}\right)$ treatments were higher than the row cover $\left(16.8^{\circ} \mathrm{C}\right)$ and low tunnel $\left(16.3^{\circ} \mathrm{C}\right)$ treatments. Row cover with water $\left(17.3^{\circ} \mathrm{C}\right)$ and low tunnel with water $\left(17.0^{\circ} \mathrm{C}\right)$ were not statistically different than the row cover and low tunnel treatments. No difference in temperatures could be seen between the treatments with row covers and those employing low tunnels. The average soil temperatures of all three seasons combined showed that there is no significant effect of season on treatment (0.29) soil temperatures. 
Table 6: Average Soil Temperatures for the Fall 2006 Season (9/19- 10/22)

Each treatment average represents the average temperatures throughout the season. SE is the standard error of the mean ( $\mathrm{N}=34$ days). Letters denote differences between treatments.

Treatments with the same letter are not significantly different from each other.

\begin{tabular}{cccc}
\hline & Differences & ${ }^{\circ}$ C Average & SE \\
\hline Control & A & 15.3 & 0.5 \\
Row Cover & B & 16.7 & 0.5 \\
Row Cover with Water & B & 16.7 & 0.5 \\
Low Tunnel & AB & 16.5 & 0.5 \\
Low Tunnel with Water & AB & 16.5 & 0.5 \\
Cold Frame & C & 18.9 & 0.3 \\
Cold Frame with Water & C & 18.5 & 0.3 \\
ANOVA & & $* * *$ & \\
Contrast & & $* * *$ & \\
Control vs. Others & & & \\
\hline
\end{tabular}

NS, $*, * * * * *$ Nonsignificant or significant at $\mathrm{P}=0.05,0.01,0.001$, respectively

Table 7: Spring 2007 Average Soil Temperatures. Each treatment average represents the average temperatures throughout the season. $\mathrm{SE}$ is the standard error of the mean ( $\mathrm{N}=63$ days) $(\mathrm{N}=42$ days for control). Letters denote differences between treatments. Treatments with the same letter are not significantly different from each other.

\begin{tabular}{ccccc}
\hline & $\begin{array}{l}\text { Differences } \\
\text { (with control) }\end{array}$ & ${ }^{\circ}$ C Average & SE & $\begin{array}{l}\text { Differences } \\
\text { (without control) }\end{array}$ \\
\hline Control & $\mathrm{C}$ & 19.9 & 0.5 & \\
Row Cover & $\mathrm{A}$ & 16.8 & 0.5 & $\mathrm{~A}$ \\
Row Cover with Water & $\mathrm{AB}$ & 17.3 & 0.4 & $\mathrm{AB}$ \\
Low Tunnel & $\mathrm{A}$ & 16.3 & 0.7 & $\mathrm{~A}$ \\
Low Tunnel with Water & $\mathrm{AB}$ & 17.0 & 0.7 & $\mathrm{AB}$ \\
Cold Frame & $\mathrm{BC}$ & 18.6 & 0.6 & $\mathrm{~B}$ \\
Cold Frame with Water & $\mathrm{BC}$ & 18.5 & 0.7 & $\mathrm{~B}$ \\
$\quad$ ANOVA & $* * *$ & & & $*$ \\
$\quad$ Contrast & $* *$ & & & \\
Control vs. Others & & & & \\
\hline
\end{tabular}

$\mathrm{NS}, *, * *, * * *$ Nonsignificant or significant at $\mathrm{P}=0.05,0.01,0.001$, respectively 


\section{Light Measurements:}

The two-week PAR averages for low tunnels, row covers, and cold frames are shown as a percentage of the control averages for comparable two-week intervals of the 2007 growing season. The low tunnel received an average $91 \%$ of the PAR of the control, while the row cover averaged $74 \%$ of the control PAR values. The amount of light in the cold frame was $77 \%$ of the control PAR levels.

Table 8: Comparison of Photosynthetically Active Radiation in $\mu \mathrm{M} / \mathrm{m}^{2} / \mathrm{sec}$ in the Season Extension Treatments. Daytime PAR averages and treatment PAR levels as a percentage of control during two-week comparative periods

\begin{tabular}{cccc}
\hline$\mu M / \mathrm{m}^{2} / \mathrm{sec}$ & Low Tunnel & Row Cover & Cold Frame \\
\hline & $5 / 8-5 / 20$ & $5 / 21-6 / 3$ & $6 / 4-6 / 17$ \\
\hline Control & 682.4 & 770.0 & 794.9 \\
Treatment & 621.5 & 566.0 & 614.1 \\
Light Levels as a Percentage of Control & $91.1 \%$ & $73.5 \%$ & $77.3 \%$ \\
\hline
\end{tabular}

\section{Total Yield:}

Two analyses of total yield were carried out for each vegetable crop in this experiment. The total yield data from the spring and the fall 2006 seasons were combined in a spring/fall 2006 analysis and the yield data from the spring 2006 and the spring 2007 seasons were combined in a spring 06/07 analysis. Results will be shown and discussed in reference to these two analyses (Appendix C).

In the spring of 2006 and 2007, cool season crops were harvested on 4/17 (6), 5/11(1-5) and 6/9 (control) and on 5/16 (6), 5/22 (1-5), and 6/8 (control), respectively. In spring 2006, warm season crops were harvested weekly from 6/23 until 8/29 while in 2007, warm season crops were harvested weekly from 6/15 until 9/5. Fall 2006 cool season crops were harvested on 10/25 (control-4), and 11/6 $(5,6)$ while fall warm season crops were harvested weekly from 10/6 until 12/1. 
Lettuce:

The combined analysis of the total yields from spring and fall 2006 (Table 9 and Figure 7) did not show differences among the field plot treatments (control- treatment 4) $(\mathrm{P}=0.60)$. Effect tests showed no significance increase in yield for the differing covers or the inclusion of water tubes in the field plot treatments. The yield in the cold frame treatments, however, was higher than all of the field plot treatments and the control. There was a difference $(<0.0001)$ between the spring and the fall season in yields with the spring yielding more than the fall season.

The combined analysis of spring 06/07 total yields did not show yield differences $(0.18)$ among the field plot treatments (control -treatment 4). There were no differences between the 2006 and 2007 years in total yield. Trends were seen as row covers and low tunnels showed slightly elevated yields, but all probabilities were greater than 0.05 and therefore not considered significant (Appendix C). The cold frame treatments produced significantly higher amounts of produce than all of the field plot treatments and the control. 
Table 9: Lettuce Average Total Yields Per Plot. Combined season yields in grams. Numbers in parentheses indicate the number assigned to each treatment for discussion purposes. SE is standard error of the mean. ( $N=6$ for control through treatment $4: \mathrm{N}=2$ for treatments 5 and 6)

\begin{tabular}{|c|c|c|c|c|}
\hline$\underline{\text { Treatment }}$ & $\begin{array}{l}\text { Total Yield } \\
\text { Spring/Fall '06 }\end{array}$ & SE & $\begin{array}{l}\text { Total Yield } \\
\text { Spring 06/ } 07\end{array}$ & SE \\
\hline Control (1) & 840 & 156 & 1300 & 326 \\
\hline Row Cover (2) & 1028 & 156 & 2083 & 326 \\
\hline Row Cover with Water (3) & 1197 & 156 & 2205 & 326 \\
\hline Low Tunnel (4) & 1062 & 156 & 1712 & 326 \\
\hline Low Tunnel with Water (5) & 1097 & 156 & 2375 & 326 \\
\hline Cold Frame (6) & 1896 & 806 & 3550 & 578 \\
\hline Cold Frame with Water (7) & 1735 & 617 & 3450 & 578 \\
\hline \multicolumn{5}{|l|}{$\underline{\text { ANOVA }}$} \\
\hline Field Plots (1-5) & NS & & NS & \\
\hline $\begin{array}{l}\text { Cold Frames (6-7) vs. Field Plots (1- } \\
\text { 5) }\end{array}$ & $*$ & & $*$ & \\
\hline $\begin{array}{l}\text { Contrasts and Effect Tests } \\
\text { Control vs. Others }\end{array}$ & & & $*$ & \\
\hline Row vs. Low & NS & & NS & \\
\hline Water Tubes vs. None & NS & & NS & \\
\hline
\end{tabular}


Radishes:

The total yield from the spring/fall 2006 analysis (Table 10) did not show yield differences (0.43) among the field plots. Effect tests showed no differences could be observed when comparing different covers or the inclusion of water tubes in the field plot treatments in the spring/ fall 2006 analysis. The total yields for the cold frame treatments were greater than all of the field plot treatments and the control (see Figure 8). Higher yields were seen in the spring season than the fall $(0.0017)$.

Differences were not seen in the total yields in the spring 06/07 analysis (0.23) among the field plot treatments (control - treatment 4). Significantly higher yields were not seen in the row cover and low tunnel treatments, as all probabilities were greater than 0.05 . Orthogonal contrasts between the experimental treatments and the control, the water tube and non-water tube treatments, and the low tunnel and row cover treatments did not show differences. However, the yields from the cold frame treatments were significantly higher than all of the field plot treatments and the control. 
Table 10: Radish Average Total Yields Per Plot. Combined season yields in grams. Numbers in parentheses indicate the number assigned to each treatment for discussion purposes. SE is standard error of the mean. ( $N=6$ for control through treatment $4: \mathrm{N}=2$ for treatments 5 and 6)

\begin{tabular}{|c|c|c|c|c|}
\hline$\underline{\text { Treatment }}$ & $\begin{array}{l}\text { Total Yield } \\
\text { Spring/Fall }\end{array}$ & SE & $\begin{array}{l}\text { Total Yield } \\
\text { Spring 06/ } 07\end{array}$ & SE \\
\hline Control (1) & 2497 & 261 & 3255 & 259 \\
\hline Row Cover (2) & 2163 & 261 & 2692 & 259 \\
\hline Row Cover with Water (3) & 2378 & 261 & 2788 & 259 \\
\hline Low Tunnel (4) & 2213 & 261 & 2363 & 259 \\
\hline Low Tunnel with Water (5) & 2818 & 261 & 2897 & 259 \\
\hline Cold Frame (6) & 5500 & 1404 & 6200 & 424 \\
\hline Cold Frame with Water (7) & 5350 & 3009 & 5275 & 424 \\
\hline \multicolumn{5}{|l|}{$\underline{\text { ANOVA }}$} \\
\hline Field Plots (1-5) & NS & & NS & \\
\hline $\begin{array}{l}\text { Cold Frames (6-7) vs. Field Plots (1- } \\
\text { 5) }\end{array}$ & $*$ & & $*$ & \\
\hline $\begin{array}{l}\text { Contrasts and Effect Tests } \\
\text { Control vs. Others }\end{array}$ & & & NS & \\
\hline Row vs. Low & NS & & NS & \\
\hline Water Tubes vs. None & NS & & NS & \\
\hline
\end{tabular}

NS, ${ }^{*}, * * * *$ Nonsignificant or significant at $\mathrm{P}=0.05,0.01,0.001$, respectively 
Arugula:

The total yields from spring 2007 (Table 11 and Figure 9) did not show treatment effects (0.67) among the field plot treatments. Orthogonal contrasts did not show any differences among the field plot treatments in the control vs. others, row cover vs. low tunnel or water tubes vs. no water tube contrasts. The yields in the cold frame treatments were significantly higher than all of the field plot treatments and the control.

Table 11: Arugula Average Total Yields Per Plot. Season yield in grams. Numbers in parentheses indicate the number assigned to each treatment for discussion purposes. SE is standard error of the mean. ( $N=6$ for control through treatment $4: \mathrm{N}=2$ for treatments 5 and 6 )

\begin{tabular}{lll}
\hline Treatment & $\begin{array}{l}\text { Total Yield } \\
\text { Spring 07 }\end{array}$ & SE \\
\hline Control (1) & 1250 & 314 \\
Row Cover (2) & 1420 & 314 \\
Row Cover with Water (3) & 1073 & 314 \\
Low Tunnel (4) & 763 & 314 \\
Low Tunnel with Water (5) & 1137 & 314 \\
Cold Frame (6) & 4900 & 348 \\
Cold Frame with Water (7) & 5150 & 348 \\
ANOVA & & \\
Field Plots (1-5) & NS \\
Cold Frames (6-7) vs. Field Plots (1- & $*$ & \\
5) & & \\
Contrasts & NS \\
Control vs. Others & & \\
Row vs. Low & NS \\
Water Tubes vs. None & NS \\
\hline
\end{tabular}

NS, $*, * * * * *$ Nonsignificant or significant at $\mathrm{P}=0.05,0.01,0.001$, respectively 


\section{Peppers:}

The analysis of the combined total yields from the spring and fall 2006 seasons (Table 12) showed that yields were not different (0.097) among the field plot treatments (control treatment 4$)$. A difference $(<0.0001)$ in yields was observed between the spring and the fall seasons, with the spring season yielding higher than the fall season. The fall control total yield was $10 \%$ of the spring yield, while the fall cold frame with water treatment was $43 \%$ of spring total yields. The fall yields of the other five treatments were similarly lower than the spring averages, with yields ranging from $18 \%$ to $30 \%$ of spring yields. There were significant differences $(0.030)$ between the row cover and low tunnel plots with and without water tubes. Row cover and low tunnel treatments with water tubes yielded $37 \%$ and $55 \%$ higher than row covers and low tunnels without water tube treatments, respectively. The yields in the cold frame treatments were higher than all of the field plot treatments and the control.

The spring 06/07 analysis depicted yield differences (0.032) among the field plot treatments in peppers (Figure 10). Orthogonal contrasts showed the control was significantly lower than the other field plots $(0.0057)$ in the combined spring 06/07 analysis. The addition of water again significantly raised yields $(0.022)$ in peppers. The row cover and low tunnel treatments with water tubes yielded $34 \%$ and $45 \%$ higher than the row cover and low tunnel treatments without water tubes. There were also yield differences between years $(0.049)$ for peppers in field plots, with 2007 total yields being higher than 2006 . The yields in the cold frame treatments were higher than all of the field plot treatments and the control in this combined spring 06/07 analysis. 
Table 12: Pepper Average Total Yields Per Plot. Combined season yields in grams. Numbers in parentheses indicate the number assigned to each treatment for discussion purposes. SE is standard error of the mean. ( $N=6$ for control through treatment $4: \mathrm{N}=2$ for treatments 5 and 6)

\begin{tabular}{lllll}
\hline Treatment & Total Yield & SE & \multicolumn{1}{l}{ Total Yield } & SE \\
& Spring/Fall '06 & & Spring 06/ 07 & \\
\hline Control (1) & 2248 & 490 & 3087 & 857 \\
Row Cover (2) & 2382 & 490 & 4908 & 857 \\
Row Cover with Water (3) & 3254 & 554 & 6599 & 857 \\
Low Tunnel (4) & 2415 & 490 & 4852 & 857 \\
Low Tunnel with Water (5) & 3748 & 490 & 7026 & 857 \\
Cold Frame (6) & 4780 & 2608 & 9853 & 1080 \\
Cold Frame with Water (7) & 6565 & 2272 & 12830 & 1080 \\
ANOVA & & & & \\
Field Plots (1-5) & NS (0.097) & & $*$ & \\
Cold Frames (6-7) vs. Field Plots (1- & $*$ & & $*$ & \\
5) Contrasts and Effect Tests & & & $* *$ & \\
\hline $\begin{array}{l}\text { Control vs. Others } \\
\text { Row vs. Low }\end{array}$ & & & $*$ & \\
Water Tubes vs. None & NS & & & \\
\hline
\end{tabular}

NS, $* * *, * * *$ Nonsignificant or significant at $\mathrm{P}=0.05,0.01,0.001$, respectively 
Tomatoes:

The field plot treatments (Table 13), including the control, in the spring/fall 2006 analysis showed differences $(0.0019)$. There was also a difference $(<0.0001)$ between the spring and the fall season, with fall yields less than $50 \%$ of the spring yields. A treatment by season $(0.0094)$ interaction was observed in 2006. Contrasts showed that the control yields were less than the other field treatments $(0.0001$.) The inclusion of water tubes was not shown to have an effect on tomato yields in the field plots. The cold frame treatments showed higher yields than all of the field plot treatments and the control.

There were also differences observed among the tomato (0.046) field plots in the spring 2006/07 analysis (Figure 11). The control again showed lower yields than the other field treatments. The presence of water and the difference between row covers and low tunnels was significant at the 0.10 level in the orthogonal contrasts, with P values of 0.093 and 0.096 , respectively. Row cover treatment yields tended to be higher than low tunnel treatments. The yields in the cold frame treatments were higher than most of the field plot treatments and the control. The only exception was the row cover with water treatment, which showed yields comparable to the two cold frame treatments. 
Table 13: Tomato Average Total Yields Per Plot. Combined season yields in grams. Numbers in parentheses indicate the number assigned to each treatment for discussion purposes. SE is standard error of the mean. ( $N=6$ for control through treatment $4: \mathrm{N}=2$ for treatments 5 and 6)

\begin{tabular}{lllll}
\hline Treatment & $\begin{array}{l}\text { Total Yield } \\
\text { Spring/Fall '06 }\end{array}$ & SE & $\begin{array}{l}\text { Total Yield } \\
\text { Spring 06/ 07 }\end{array}$ & SE \\
\hline Control (1) & 1425 & 1477 & 6100 & 6968 \\
Row Cover (2) & 8365 & 1477 & 15598 & 3455 \\
Row Cover with Water (3) & 11065 & 1477 & 22065 & 2774 \\
Low Tunnel (4) & 8392 & 1477 & 13393 & 2774 \\
Low Tunnel with Water (5) & 10280 & 1477 & 15646 & 2774 \\
Cold Frame (6) & 16550 & 12487 & 27400 & 2524 \\
Cold Frame with Water (7) & 18070 & 15115 & 27970 & 2524 \\
ANOVA & & & & \\
Field Plots (1-5) & $* *$ & & $*$ & \\
$\begin{array}{l}\text { Cold Frames (6-7) vs. Field Plots (1- } \\
\text { 5) }\end{array}$ & $*$ & & $*$ & \\
Contrasts and Effect Tests & $* * *$ & & NS (0.096) & \\
$\begin{array}{l}\text { Control vs. Others } \\
\text { Row vs. Low }\end{array}$ & NS & & NS (0.093) & \\
Water Tubes vs. None & NS & & & \\
\hline
\end{tabular}

NS, $*, * * * * *$ Nonsignificant or significant at $\mathrm{P}=0.05,0.01,0.001$, respectively 


\section{Regression Analysis:}

In order to understand how temperatures were related to total yield, a regression analysis was carried out using the average total yield per plot and the average air and soil temperature for each treatment (Table 14). Separate analyses were completed for both air and soil temperature for each crop in the spring (combined 2006 and 2007) and fall (2006) seasons (Appendix D). Lettuce:

In the spring 2006 and 2007 seasons, the regression analysis showed a correlation between the average air temperature and total yield for lettuce with an $\mathrm{R}^{2}$ value of 0.28 $(\mathrm{P}=0.0014)$. The $\mathrm{R}^{2}$ value for the correlation between the average fall 2006 air temperature and the total yield was $0.66(<0.0001)$.

In the spring 2006 and 2007 seasons, the correlation between the average soil temperature and total yield for lettuce had an $\mathrm{R}^{2}$ value of $0.34(\mathrm{P}=0.0006)$. The $\mathrm{R}^{2}$ value for the correlation between the average fall 2006 soil temperature and the total yield was $0.65(<0.0001)$. Radish:

In the spring 06/07 regression analysis, the correlation between the average air temperature and total yield for radish had an $\mathrm{R}^{2}$ value of $0.04(0.25)$. The $\mathrm{R}^{2}$ value for the correlation between the average fall 2006 air temperature and the total yield was 0.55 (0.0006).

The spring 06/07 regression analysis showed a correlation between the average soil temperature and total yield for radish with an $\mathrm{R}^{2}$ value of $0.22(0.008)$. The $\mathrm{R}^{2}$ value for the correlation between the average fall 2006 soil temperature and the total yield was 0.70 $(<0.0001)$. 
Arugula:

In the spring 2007 regression analysis, the correlation between the average air temperature and total yield for arugula had an $\mathrm{R}^{2}$ value of $0.22(0.056)$. The correlation between the total yield and average soil temperature had an $\mathrm{R}^{2}$ value of $0.80(<0.0001)$. Pepper:

The spring 06/07 regression analysis showed a correlation between the average air temperature and total yield for bell pepper with an $\mathrm{R}^{2}$ value of $0.33(\mathrm{P}=0.0004)$. The $\mathrm{R}^{2}$ value for the correlation between the average fall 2006 air temperature and the total yield was 0.44 $(0.0035)$.

In the spring 06/07 regression analysis, the correlation between the average soil temperature and total yield for pepper had an $\mathrm{R}^{2}$ value of $0.45(<0.0001)$. The $\mathrm{R}^{2}$ value for the correlation between the average fall 2006 soil temperature and the total yield was $0.55(0.0006)$. Tomato:

The spring 06/07 regression analysis showed a correlation between the average air temperature and total yield for tomato with an $\mathrm{R}^{2}$ value of $0.41(0.0009)$. The $\mathrm{R}^{2}$ value for the correlation between the average fall 2006 air temperature and the total yield was $0.48(0.002)$.

In the spring 2006 and 2007 seasons, the correlation between the average soil temperature and total yield for tomato had a $0.43 \mathrm{R}^{2}$ value $(\mathrm{P}=<0.0001)$. The $\mathrm{R}^{2}$ value for the correlation between the average fall 2006 soil temperature and the total yield was $0.54(0.0008)$. 
Table 14: Regression Analysis $\mathrm{R}^{2}$ Values

\begin{tabular}{lllllll}
\hline & Vegetable & Lettuce & Radish & Arugula & Pepper & Tomato \\
\hline Spring & & & & & & \\
& Air Temp R & 0.28 & 0.04 & 0.22 & 0.33 & 0.41 \\
& & & & & & \\
\multirow{2}{*}{ Fall } & Soil Temp R & 0.34 & 0.22 & 0.80 & 0.45 & 0.43 \\
& & & & & & \\
& Air Temp R & 0.66 & 0.55 & N/A & 0.44 & 0.48 \\
& & & & & & \\
& Soil Temp R & 0.65 & 0.70 & N/A & 0.55 & 0.54 \\
\hline
\end{tabular}




\section{Early Yield:}

Pepper:

Pepper early yields (before the first control harvest) were different (0.0004) among treatments (Table 15 and Figure 12) in the combined analysis of spring 06/07 (Appendix E). Differences were also observed $(<0.0001)$ between the 2006 and 2007 spring seasons. 2007 showed higher early yields than 2006. The presence of water tubes in the field plots was shown to increase $(0.00065)$ early yield. Row cover and low tunnel treatments with water tubes had early yields $79 \%$ and $84 \%$ higher than the row cover and low tunnel treatments without water tubes. However, the presence of water in the cold frames did not significantly affect early yields. Early pepper yield was higher (0.039) in the cold frame treatments than in the field plot treatments.

Table 15: Pepper Average Early Yield Per Plot. Combined season yields in grams. Numbers in parentheses indicate the number assigned to each treatment for discussion purposes. SE is standard error of the mean. ( $N=6$ for control through treatment $4: \mathrm{N}=2$ for treatments 5 and 6)

\begin{tabular}{lll}
\hline Treatments & $\begin{array}{l}\text { Early Yield } \\
\text { Spring 06/07 }\end{array}$ & \\
\hline Row Cover (2) & 1427 & 367 \\
Row Cover with Water (3) & 2549 & 367 \\
Low Tunnel (4) & 1394 & 367 \\
Low Tunnel with Water (5) & 2569 & 367 \\
Cold Frame (6) & 4213 & 636 \\
Cold Frame with Water (7) & 5285 & 636 \\
ANOVA & & \\
Treatments (2-7) & $* *$ & \\
Field Plots (2-5) vs. Cold Frame (6-7) & $*$ & \\
Contrasts & & \\
Water vs. None & $* *$ \\
Row vs. Low & NS \\
\hline
\end{tabular}

NS, *,**,** Nonsignificant or significant at $\mathrm{P}=0.05,0.01,0.001$, respectively 
Tomato:

There were differences among the six experimental treatments $(<0.0001)$ in the combined spring 06/07 analysis of yields (Table 16 and Figure 13). Again a difference in early yields $(<0.0001)$ was observed when comparing the 2006 and 2007 seasons. 2006 showed higher early yields than 2007. The presence of water in the field plot treatments $(0.12)$, nor in the cold frames increased early yields. Early yields were again (see peppers) higher $(<0.0001)$ in the cold frames than in the field plots. A treatment*year effect $(<0.0001)$ was observed in the early yields of tomatoes.

Table 16: Tomato Average Early Yield Per Plot. Combined season yields in grams. Numbers in parentheses indicate the number assigned to each treatment for discussion purposes. SE is standard error of the mean. $(\mathrm{N}=6$ for control through treatment $4: \mathrm{N}=2$ for treatments 5 and 6)

\begin{tabular}{lll}
\hline Treatments & $\begin{array}{l}\text { Early Yield } \\
\text { Spring 06/07 }\end{array}$ \\
\hline Row Cover (2) & 1192 & 289 \\
Row Cover with Water (3) & 1497 & 289 \\
Low Tunnel (4) & 444 & 289 \\
Low Tunnel with Water (5) & 1083 & 289 \\
Cold Frame (6) & 12975 & 501 \\
Cold Frame with Water (7) & 18960 & 501 \\
ANOVA & & \\
Treatments (2-7) & $* * *$ & \\
Field Plots (2-5) vs. Cold Frame (6-7) & $* * *$ \\
Contrasts & NS (0.12) \\
Water vs. None & \\
Row vs. Low & NS \\
\hline NS, * **, *** Nonsignificant or significant at P=0.05,0.01, 0.001, respectively
\end{tabular}




\section{Economic Analysis:}

The control plot has the lowest potential return of $\$ 82.89$ and the cold frame with water treatment has the highest with $\$ 328.93$ (Table 17). The other five treatments fell in between

with the row cover, low tunnel, and cold frame with water tubes showing higher possible returns than their respective treatments without water tubes. In 2006, the low tunnel treatments showed higher potential profits than the row cover treatments.

The 2007 potentials return analysis (Table 18) looks very similar to the 2006 analysis with the addition of an arugula crop, which replaced the poor spinach crop of 2006 (see above). The control treatment plot again has the lowest economic potential of $\$ 97.55$ while the cold frame with water added has the highest potential income of $\$ 344.01$. As with the 2006 analysis the treatments with water tubes show higher average yields and therefore increased profits. In contrast to the 2006 analysis, the row covers showed generally higher returns than the low tunnel treatments. 
Table 17: Estimated Returns for Spring 2006

Average early and regular (after early) season yields for each crop in a 3.7 x $4.9 \mathrm{~m}$ plot are multiplied by the price per pound that was received in that portion of the season at our local market to obtain estimated gross returns for each treatment (pounds were used due to pricing methods in our market). All lettuce and radish yields were considered early since all were harvested before the control.

\begin{tabular}{|c|c|c|c|c|c|c|c|c|c|}
\hline $\begin{array}{l}\text { Early } \\
\text { Yield }\end{array}$ & & & & & & & & & \\
\hline & & & Control & Row & Row $\mathrm{H}_{2} \mathrm{O}$ & Low & Low $\mathrm{H}_{2} \mathrm{O}$ & $\mathbf{C F}$ & $\mathrm{CF} \mathrm{H}_{2} \mathrm{O}$ \\
\hline & RADISH & Pounds & 0 & 6.1 & 7.7 & 7.4 & 7.7 & 10.6 & 10.6 \\
\hline \multirow[t]{2}{*}{$\begin{array}{l}\text { Price per } \\
\text { pound }\end{array}$} & $\$ 1.35$ & $\$ / l b \times l b$ & 0 & 8.24 & 10.42 & 10.05 & 10.42 & 14.24 & 14.35 \\
\hline & LETTUCE & Pounds & 0 & 8.8 & 11.8 & 10.4 & 12.5 & 16.1 & 9.3 \\
\hline \multirow[t]{2}{*}{$\begin{array}{l}\text { Price per } \\
\text { pound }\end{array}$} & $\$ 2.25$ & $\$ / l b \times l b$ & 0 & 19.73 & 26.64 & 23.41 & 28.22 & 36.32 & 20.82 \\
\hline & TOMATO & Pounds & 0 & 6.4 & 7.5 & 2.7 & 6.3 & 62.6 & 91.8 \\
\hline \multirow[t]{2}{*}{$\begin{array}{l}\text { Price per } \\
\text { pound }\end{array}$} & $\$ 2.00$ & $\$ / l b \times l b$ & 0 & 12.73 & 15.04 & 5.49 & 12.65 & 125.20 & 183.62 \\
\hline & PEPPER & Pounds & 0 & 2.2 & 4.4 & 1.4 & 4.5 & 10.8 & 1089 \\
\hline $\begin{array}{l}\text { Price per } \\
\text { pound }\end{array}$ & $\$ 1.50$ & $\$ / l b \times l b$ & 0 & 3.23 & 6.60 & 2.07 & 6.75 & 16.24 & 16.18 \\
\hline & & & & & & & & & \\
\hline \multicolumn{10}{|l|}{$\frac{\text { Regular }}{\text { Yield }}$} \\
\hline & & & Control & Row & Row $\mathrm{H}_{2} \mathrm{O}$ & Low & Low $\mathrm{H}_{2} \mathrm{o}$ & $\mathbf{C F}$ & $\mathrm{CF} \mathrm{\textrm {H } _ { 2 } \mathrm { o }}$ \\
\hline & RADISH & Pounds & 12.4 & 0 & 0 & 0 & 0 & 0 & 0 \\
\hline \multirow[t]{2}{*}{$\begin{array}{l}\text { Price per } \\
\text { pound }\end{array}$} & $\$ 1.35$ & $\$ / l b \times l b$ & 16.76 & 0 & 0 & 0 & 0 & 0 & 0 \\
\hline & LETTUCE & & 6.3 & 0 & 0 & 0 & 0 & 0 & 0 \\
\hline \multirow[t]{2}{*}{$\begin{array}{l}\text { Price per } \\
\text { pound }\end{array}$} & $\$ 2.25$ & $\$ / l b \times l b$ & 14.08 & 0 & 0 & 0 & 0 & 0 & 0 \\
\hline & TOMATO & Pounds & 18.6 & 42.0 & 72.3 & 58.3 & 63.9 & 51.6 & 38.7 \\
\hline \multirow[t]{2}{*}{$\begin{array}{l}\text { Price per } \\
\text { pound }\end{array}$} & $\$ 1.50$ & $\$ / l b \times l b$ & 27.89 & 63.05 & 108.38 & 87.48 & 95.81 & 77.36 & 57.99 \\
\hline & PEPPER & Pounds & 16.1 & 13.8 & 12.9 & 14.3 & 27.8 & 18.2 & 24.0 \\
\hline $\begin{array}{c}\text { Price per } \\
\text { pound }\end{array}$ & $\$ 1.50$ & $\$ / l b \times l b$ & 24.15 & 20.65 & 19.35 & 21.4 & 41.73 & 27.34 & 35.96 \\
\hline $\begin{array}{c}\text { Total } \\
\text { returns } \\
\text { per } \\
\text { treatment } \\
\text { replicate } \\
\end{array}$ & Total \$ & & $\$ 82.89$ & $\$ 127.62$ & $\$ 186.42$ & $\$ 149.89$ & $\$ 195.58$ & $\$ 296.7$ & $\$ 328.93$ \\
\hline
\end{tabular}


Table 18: Estimated Returns for Spring 2007

Average early and regular (after early) season yields for each crop in a 3.7 x $4.9 \mathrm{~m}$ plot are multiplied by the price per pound that was received in that portion of the season at our local market to obtain estimated gross returns for each treatment (pounds were used due to pricing methods in our market). All lettuce, radish, and arugula yields were considered early yields since all were harvested before the control.

\begin{tabular}{|c|c|c|c|c|c|c|c|c|c|}
\hline$\frac{\text { Early }}{\text { Yield }}$ & & & Control & Row & $\operatorname{Row} \mathrm{H}_{2} \mathrm{O}$ & Low & Low $\mathrm{H}_{2} \mathrm{o}$ & $\mathbf{C F}$ & $\mathrm{CF} \mathrm{H}_{2} \mathrm{O}$ \\
\hline & RADISH & Pounds & 0 & 9.7 & 5.1 & 8.2 & 10.3 & 32.7 & 32.3 \\
\hline \multirow[t]{2}{*}{$\begin{array}{l}\text { Price per } \\
\text { pound }\end{array}$} & $\$ 1.35$ & $\$ / l b \times l b$ & 0 & 13.06 & 6.93 & 11.07 & 13.86 & 44.11 & 43.58 \\
\hline & LETTUCE & Pounds & 0 & 10.3 & 9.6 & 6.0 & 11.0 & 17.3 & 16.7 \\
\hline \multirow[t]{2}{*}{$\begin{array}{l}\text { Price per } \\
\text { pound }\end{array}$} & $\$ 2.25$ & $\$ / l b \times l b$ & 0 & 23.18 & 21.7 & 13.58 & 24.71 & 38.98 & 37.65 \\
\hline & ARUGULA & Pounds & 0 & 3.8 & 4.2 & 3.0 & 4.5 & 19.3 & 20.3 \\
\hline \multirow{2}{*}{$\begin{array}{l}\text { Price per } \\
\text { pound }\end{array}$} & $\$ 1.50$ & $\$ / l b \times l b$ & 0 & 5.67 & 6.34 & 4.51 & 6.71 & 28.94 & 30.41 \\
\hline & TOMATO & Pounds & 0 & 3.0 & 4.3 & 0.8 & 2.12 & 39.6 & 57.5 \\
\hline \multirow[t]{2}{*}{$\begin{array}{l}\text { Price per } \\
\text { pound }\end{array}$} & $\$ 2.00$ & $\$ / l b \times l b$ & 0 & 6.04 & 8.53 & 1.51 & 4.4 & 79.13 & 114.96 \\
\hline & PEPPER & Pounds & 0 & 9.1 & 15.7 & 9.6 & 15.7 & 22.3 & 30.8 \\
\hline $\begin{array}{l}\text { Price per } \\
\text { pound }\end{array}$ & $\$ 1.50$ & $\$ / l b \times l b$ & 0 & 13.62 & 23.52 & 14.4 & 23.59 & 33.51 & 46.24 \\
\hline \multirow[t]{3}{*}{$\frac{\text { Regular }}{\underline{\text { Yield }}}$} & & & Pounds & Pounds & Pounds & Pounds & Pounds & Pounds & Pounds \\
\hline & & & Control & Row & $\operatorname{Row} \mathbf{H}_{2} \mathbf{0}$ & Low & Low $\mathrm{H}_{2} \mathrm{o}$ & $\mathbf{C F}$ & $\mathrm{CF} \mathrm{H}_{2} \mathrm{O}$ \\
\hline & RADISH & Pounds & 13.2 & 0 & 0 & 0 & 0 & 0 & 0 \\
\hline \multirow[t]{2}{*}{$\begin{array}{l}\text { Price per } \\
\text { pound }\end{array}$} & $\$ 1.35$ & $\$ / l b \times l b$ & 17.84 & 0 & 0 & 0 & 0 & 0 & 0 \\
\hline & LETTUCE & Pounds & 4.0 & 0 & 0 & 0 & 0 & 0 & 0 \\
\hline \multirow[t]{2}{*}{$\begin{array}{l}\text { Price per } \\
\text { pound }\end{array}$} & $\$ 2.25$ & $\$ / l b \times l b$ & 8.95 & 0 & 0 & 0 & 0 & 0 & 0 \\
\hline & ARUGULA & Pounds & 4.9 & 0 & 0 & 0 & 0 & 0 & 0 \\
\hline \multirow[t]{2}{*}{$\begin{array}{l}\text { Price per } \\
\text { pound }\end{array}$} & $\$ 1.50$ & $\$ / l b \times l b$ & 7.38 & 0 & 0 & 0 & 0 & 0 & 0 \\
\hline & TOMATO & Pounds & 39.0 & 59.4 & 89.7 & 43.6 & 50.7 & 62.0 & 32.3 \\
\hline \multirow[t]{2}{*}{$\begin{array}{l}\text { Price per } \\
\text { pound }\end{array}$} & $\$ 1.50$ & $\$ / l b \times l b$ & 58.46 & 89.07 & 134.55 & 65.45 & 76.08 & 93.01 & 48.43 \\
\hline & PEPPER & Pounds & 8.2 & 13.6 & 19.0 & 13.0 & 16.3 & 26.2 & 35.4 \\
\hline $\begin{array}{l}\text { Price per } \\
\text { pound }\end{array}$ & $\$ 1.50$ & $\$ / l b \times l b$ & 12.30 & 20.47 & 28.51 & 19.44 & 24.41 & 39.27 & 53.15 \\
\hline $\begin{array}{c}\text { Total } \\
\text { return } \\
\text { per } \\
\text { treatment } \\
\text { replicate } \\
\end{array}$ & Total \$ & & 97.55 & 165.45 & 223.72 & 125.45 & 167.05 & 328.02 & 344.01 \\
\hline
\end{tabular}


The low tunnel and row cover treatments were the least expensive with an additional cost associated with implementing the treatments of $\$ 10.70$ and $\$ 12.32$ per plot, respectively (Table 19). The addition of water tubes to these treatments raised the cost to $\$ 31.70$ and $\$ 33.32$, respectively. The two cold frame treatments, with and without water, were the most expensive treatments with yearly additional costs of $\$ 191.68$ and $\$ 95.83$, respectively. The cold frame with water treatment was more expensive due to the water wall and compost system, which besides the additional cost of material and labor, used only half the growing space available in the cold frame with the water wall and compost system consuming half of the cold frame growing area.

Table 19: Added Costs The additional costs associated with each treatment plot that were in excess of labor and material expense incurred for the control

\begin{tabular}{|c|c|c|c|c|c|c|c|}
\hline \multicolumn{8}{|c|}{ ADDITIONAL COSTS for a 3.7 x $4.9 \mathrm{~m}$ plot } \\
\hline & Control & Row & Row $\mathrm{H}_{2} \mathbf{0}$ & Low & Low $\mathrm{H}_{2} \mathrm{O}$ & $\mathbf{C F}$ & $\mathrm{CF} \mathrm{H}_{2} \mathrm{O}$ \\
\hline \multicolumn{8}{|l|}{ Labor $\$ 6 / \mathrm{hr}$} \\
\hline $\mathrm{H}_{2} \mathbf{0}$ tubes/wall labor & 0 & 0 & 12.00 & 0 & 12.00 & 0 & 12.00 \\
\hline Construction labor & 0 & 3.00 & 3.00 & 3.00 & 3.00 & 9.60 & 14.40 \\
\hline Covering & 0 & 5.82 & 5.82 & 4.20 & 4.20 & 23.63 & 47.25 \\
\hline Frame/wire & 0 & 3.50 & 3.50 & 3.50 & 3.50 & 35.80 & 71.60 \\
\hline $\mathbf{H}_{2} \mathbf{O}$ tubes/wall & 0 & 0 & 9.00 & 0 & 9.00 & 0 & 16.13 \\
\hline Other & 0 & 0 & 0 & 0 & 0 & 8.80 & 12.30 \\
\hline Maintenance & 0 & 0 & 0 & 0 & 0 & 18.00 & 18.00 \\
\hline Total \$ & 0 & 12.32 & 33.32 & 10.70 & 31.70 & 95.83 & 191.68 \\
\hline
\end{tabular}


When the additional costs are subtracted from the potential returns (Table 20), a comparison of potential profit between the treatments emerges. Control returns are the lowest of all treatments in both years while the highest potential returns can be found in cold frame without water treatment both years of the experiment. In the cold frame treatments, however, in both years the estimated returns from the cold frame with water treatment are lower than the cold frame without water treatment.

Table 20: Estimated Net Returns Estimated costs were subtracted from potential returns calculated in Tables 17 and 18 to obtain estimated net returns for each plot

\section{Comparisons}

\begin{tabular}{|c|c|c|c|c|c|c|c|c|}
\hline & 2006 & Control & Row & Row $\mathbf{H}_{2} \mathbf{0}$ & Low & Low $\mathbf{H}_{2} \mathrm{O}$ & CF & $\mathrm{CF} \mathrm{H}_{2} \mathrm{O}$ \\
\hline Income & & 82.89 & $\quad 127.62$ & $\quad 186.42$ & 149.89 & 195.58 & 296.7 & 328.93 \\
\hline Added costs & & 0 & 12.32 & 33.32 & 10.70 & 31.70 & 95.83 & 191.68 \\
\hline Net returns & & $\$ 82.89$ & $\$ 115.30$ & $\$ 153.10$ & $\$ 139.19$ & $\$ 163.88$ & $\$ 200.87$ & $\$ 137.25$ \\
\hline & 2007 & & & & & & & \\
\hline Income & & 97.55 & 165.45 & 223.72 & 125.45 & 167.05 & 328.02 & 344.01 \\
\hline Added costs & & 0 & 12.32 & 33.32 & 10.70 & 31.70 & 95.83 & 191.68 \\
\hline Net returns & & $\$ 97.55$ & $\$ 153.13$ & $\$ 190.40$ & $\$ 114.75$ & $\$ 135.35$ & $\$ 232.19$ & $\$ 152.33$ \\
\hline
\end{tabular}


Figure 1: Average air temperatures in ${ }^{\circ} \mathrm{C}$ for each of the seven treatments in Spring 2006 with standard error represented by the error bars.

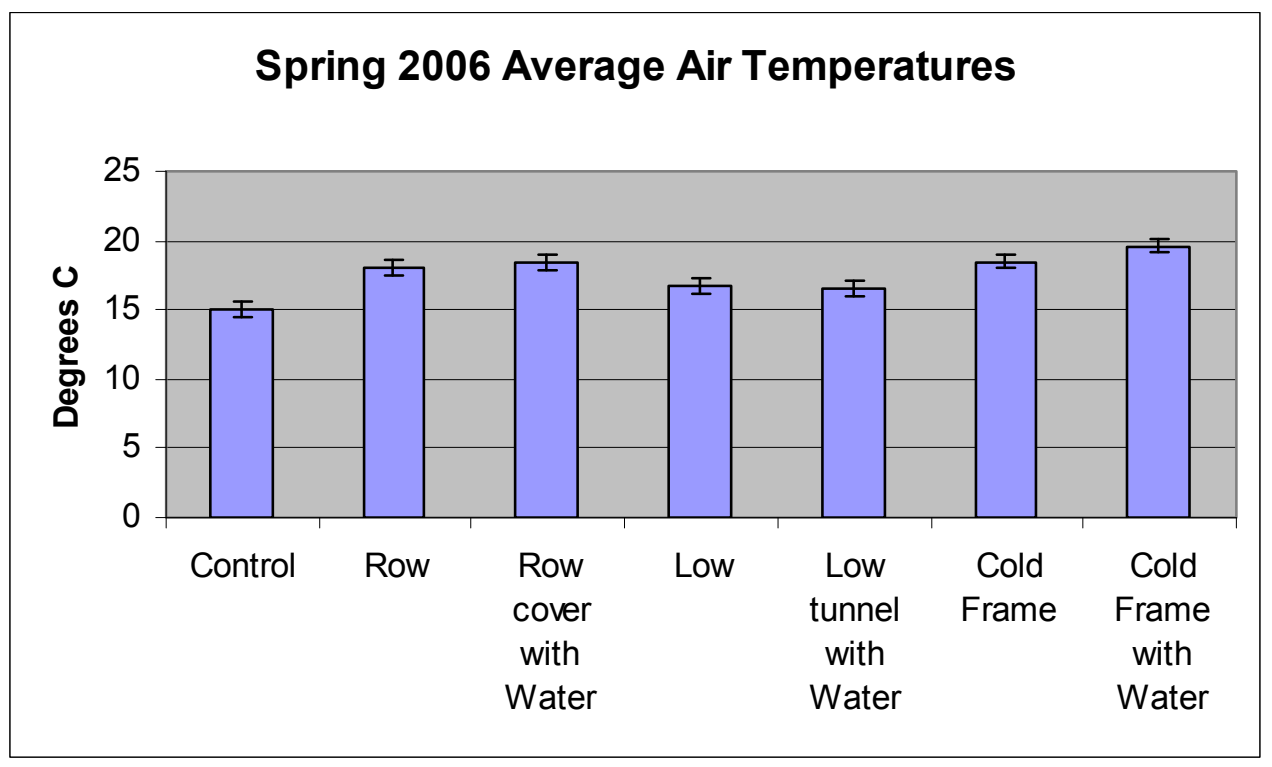

Figure 2: Average air temperatures in ${ }^{\circ} \mathrm{C}$ for each of the seven treatments in Fall 2006 with standard error represented by the error bars.

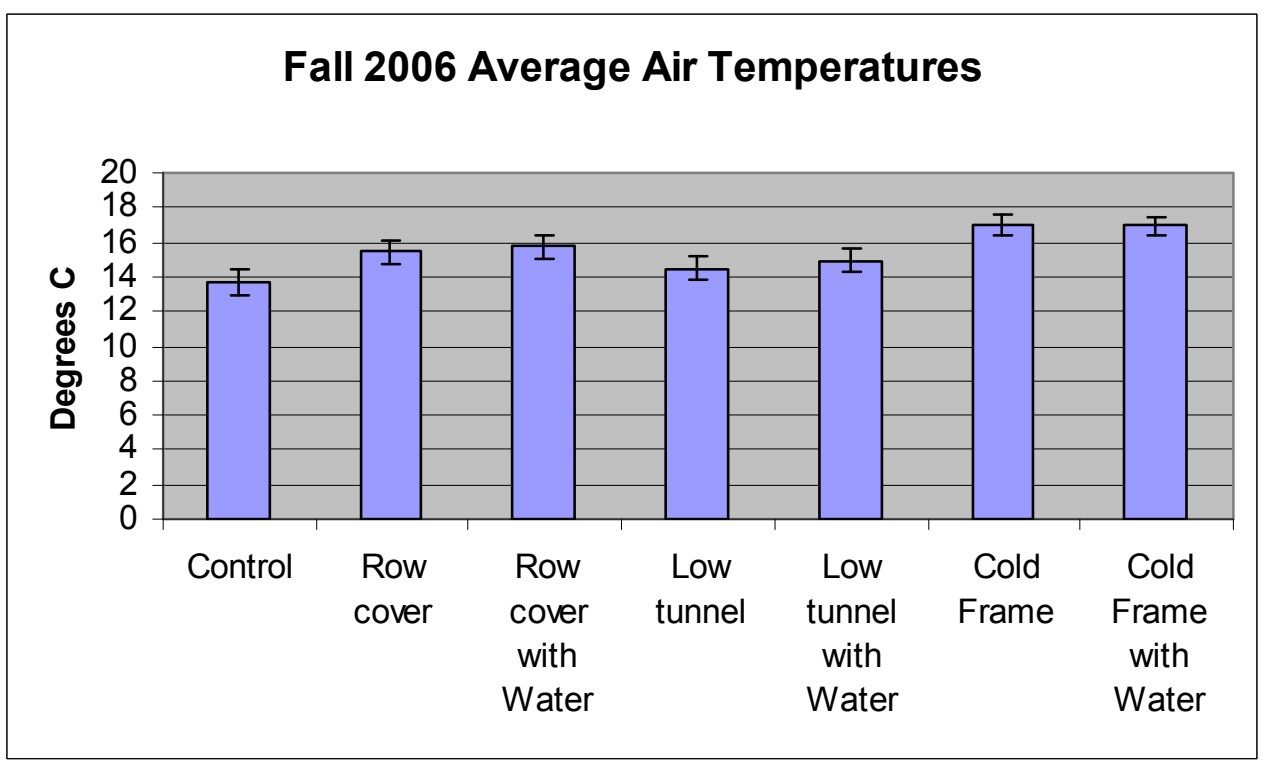


Figure 3: Average air temperatures in ${ }^{\circ} \mathrm{C}$ for each of the seven treatments in Spring 2007 with standard error represented by the error bars.

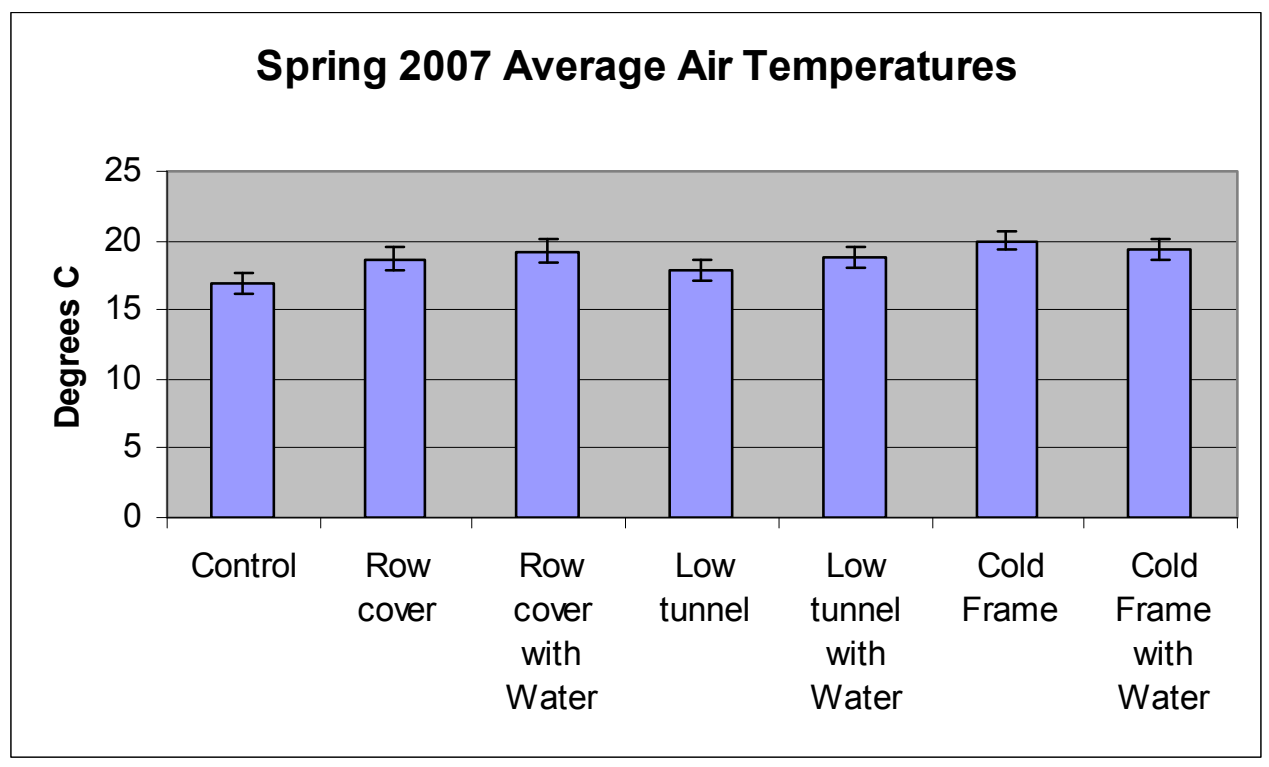

Figure 4: Average soil temperatures in ${ }^{\circ} \mathrm{C}$ for each of the seven treatments in Spring 2006 with standard error represented by the error bars.

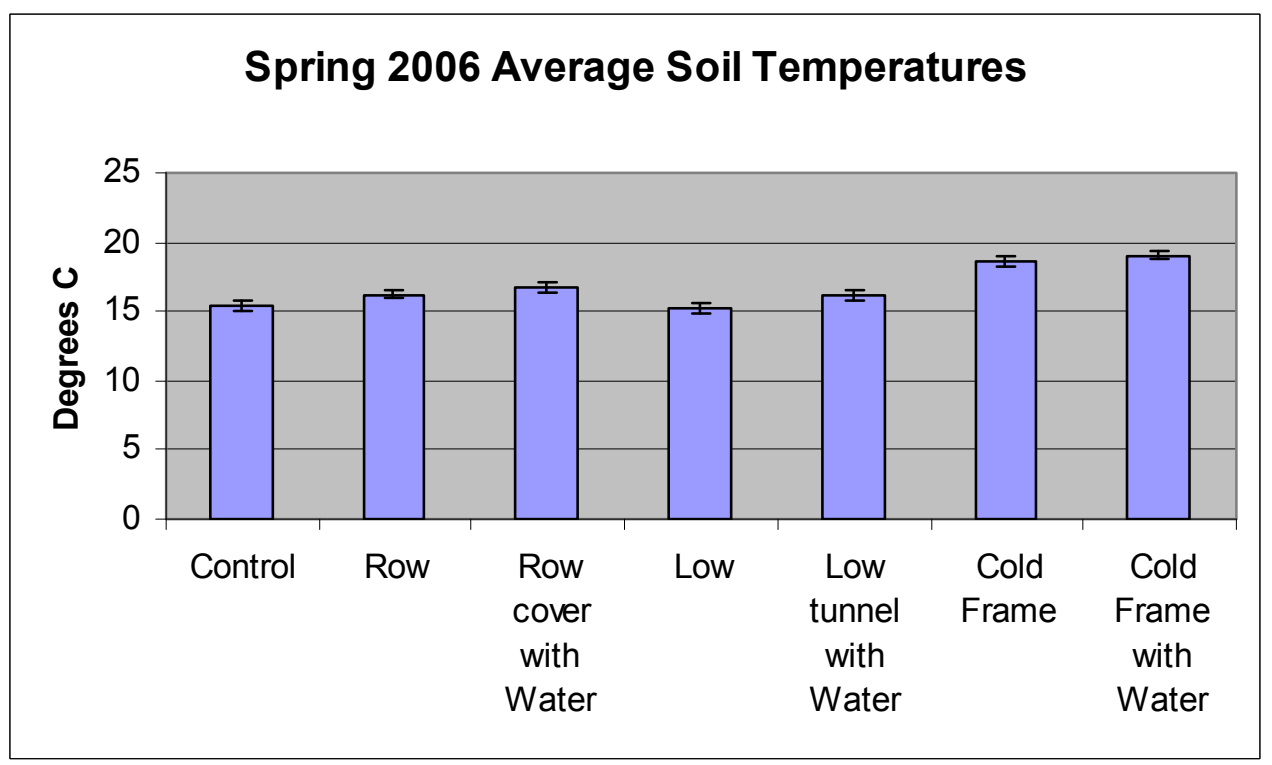


Figure 5: Average soil temperatures in ${ }^{\circ} \mathrm{C}$ for each of the seven treatments in Spring 2006 with standard error represented by the error bars.

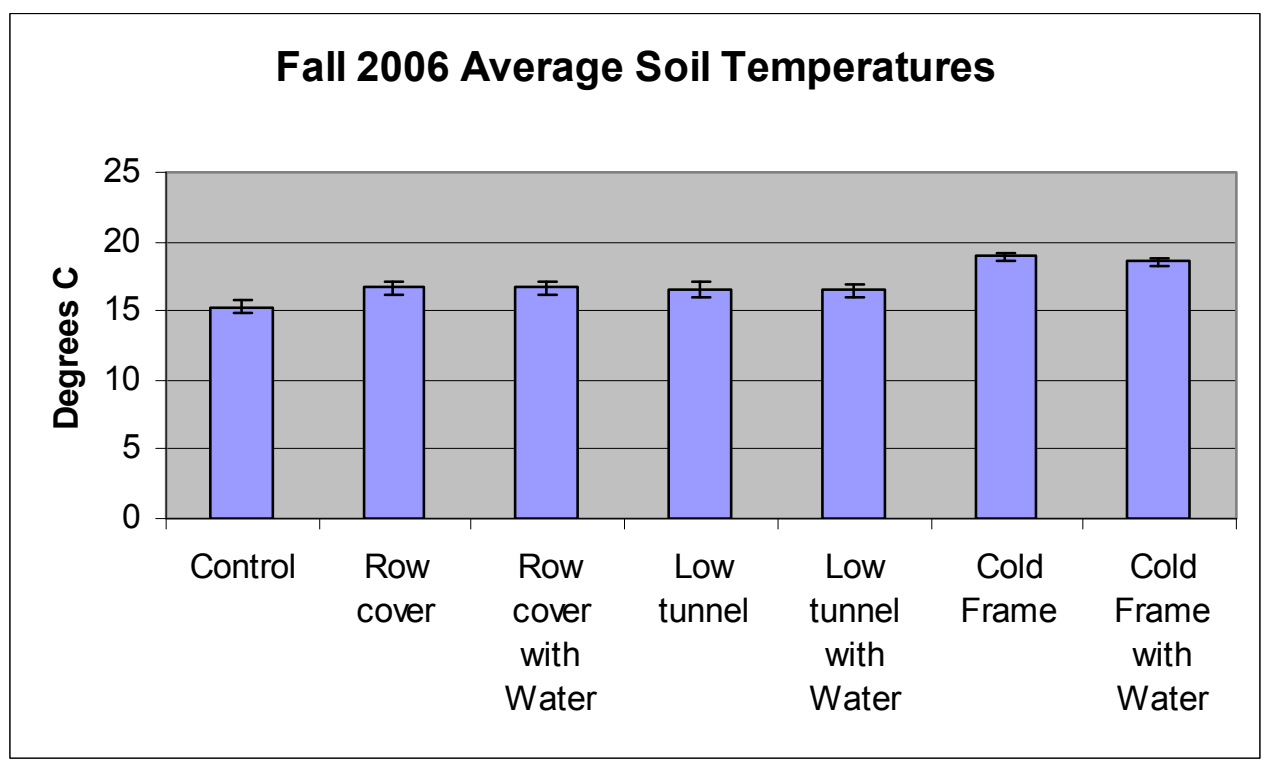

Figure 6: Average soil temperatures in ${ }^{\circ} \mathrm{C}$ for each of the seven treatments in Spring 2006 with standard error represented by the error bars.

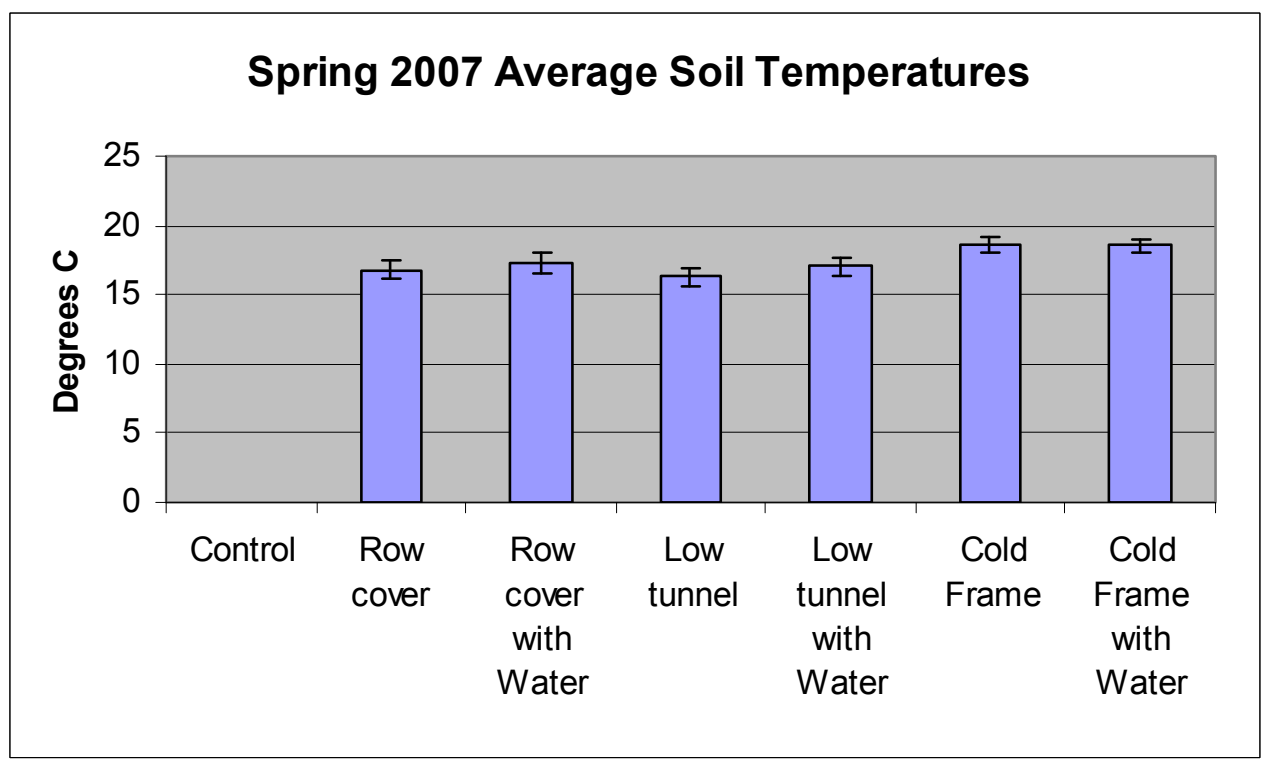


Figure 7: Combined fall and spring or spring and spring average total yields per 3.7 by $4.9 \mathrm{~m}$ plot. Error bars represent standard error.

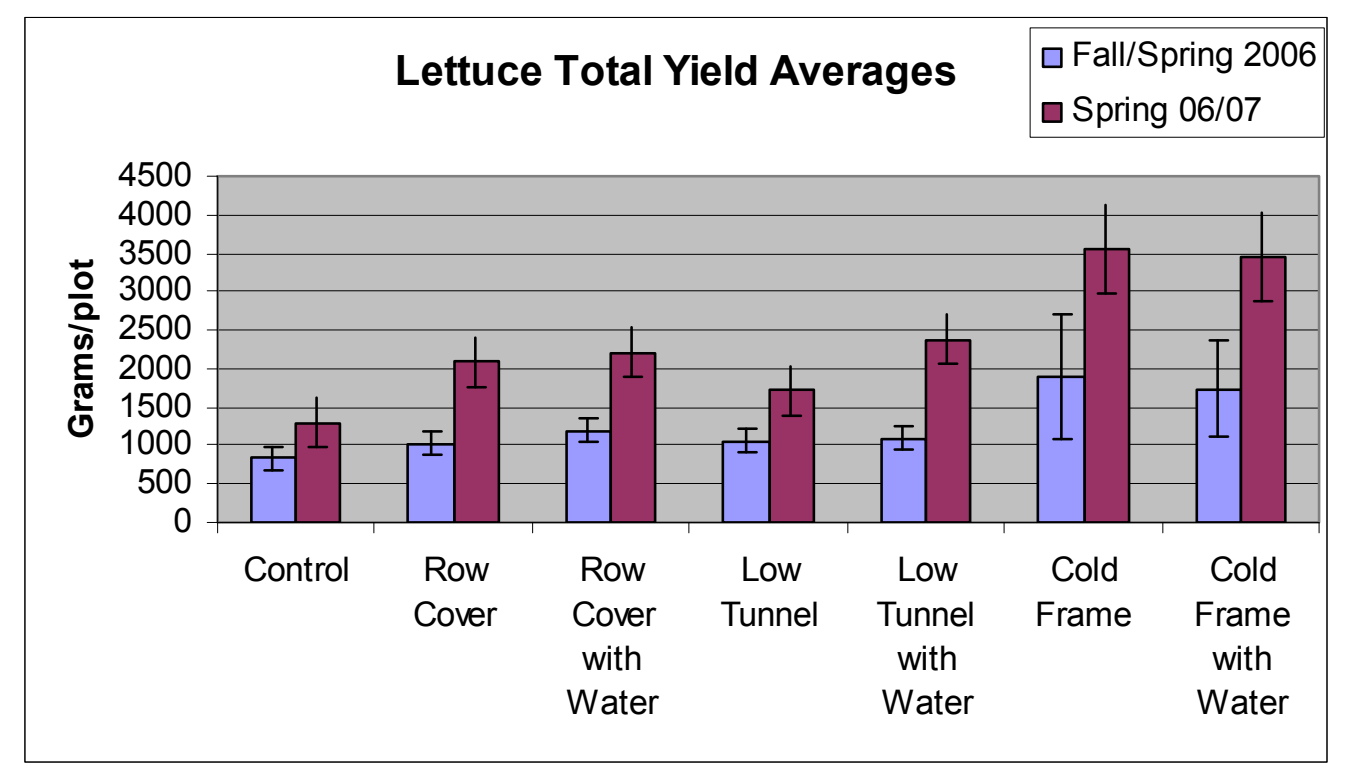

Figure 8: Combined fall and spring or spring and spring average total yields per 3.7 by $4.9 \mathrm{~m}$ plot. Error bars represent standard error.

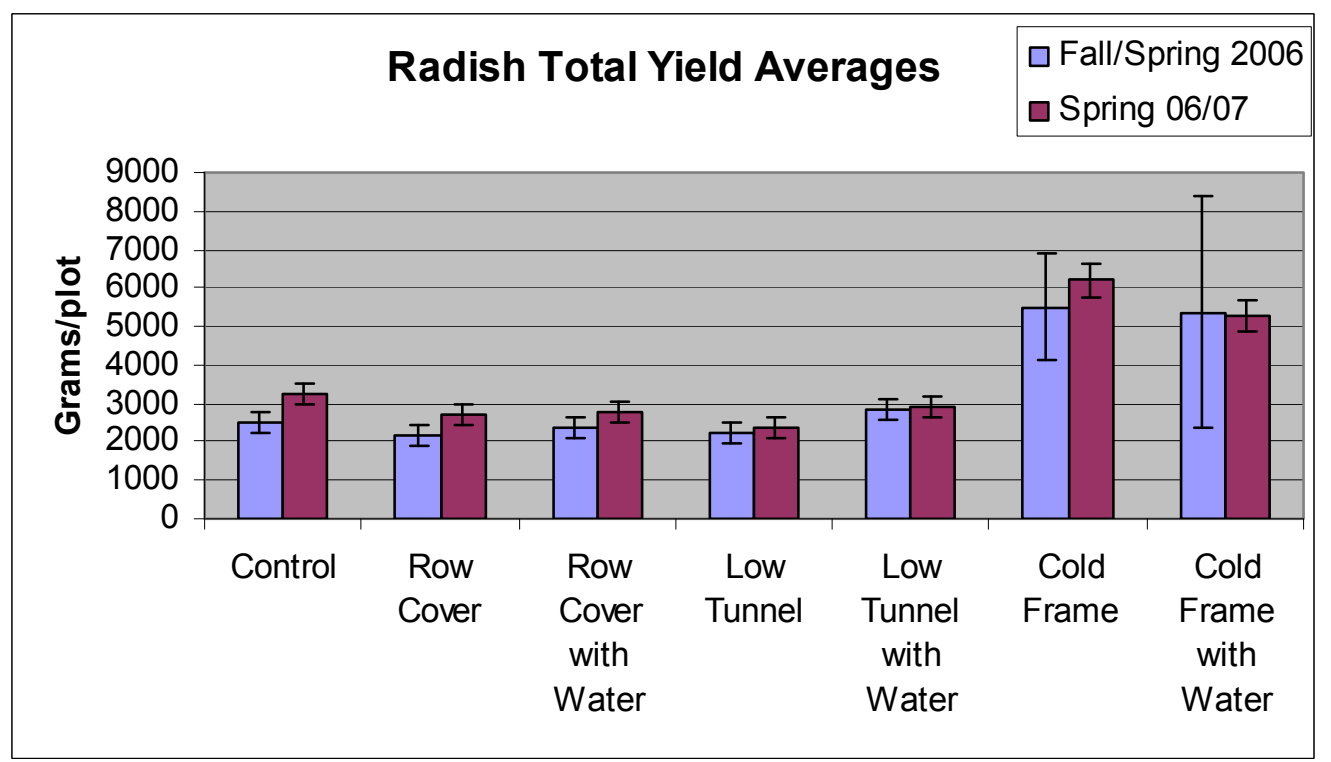


Figure 9: Combined fall and spring or spring and spring average total yields per 3.7 by $4.9 \mathrm{~m}$ plot. Error bars represent standard error.

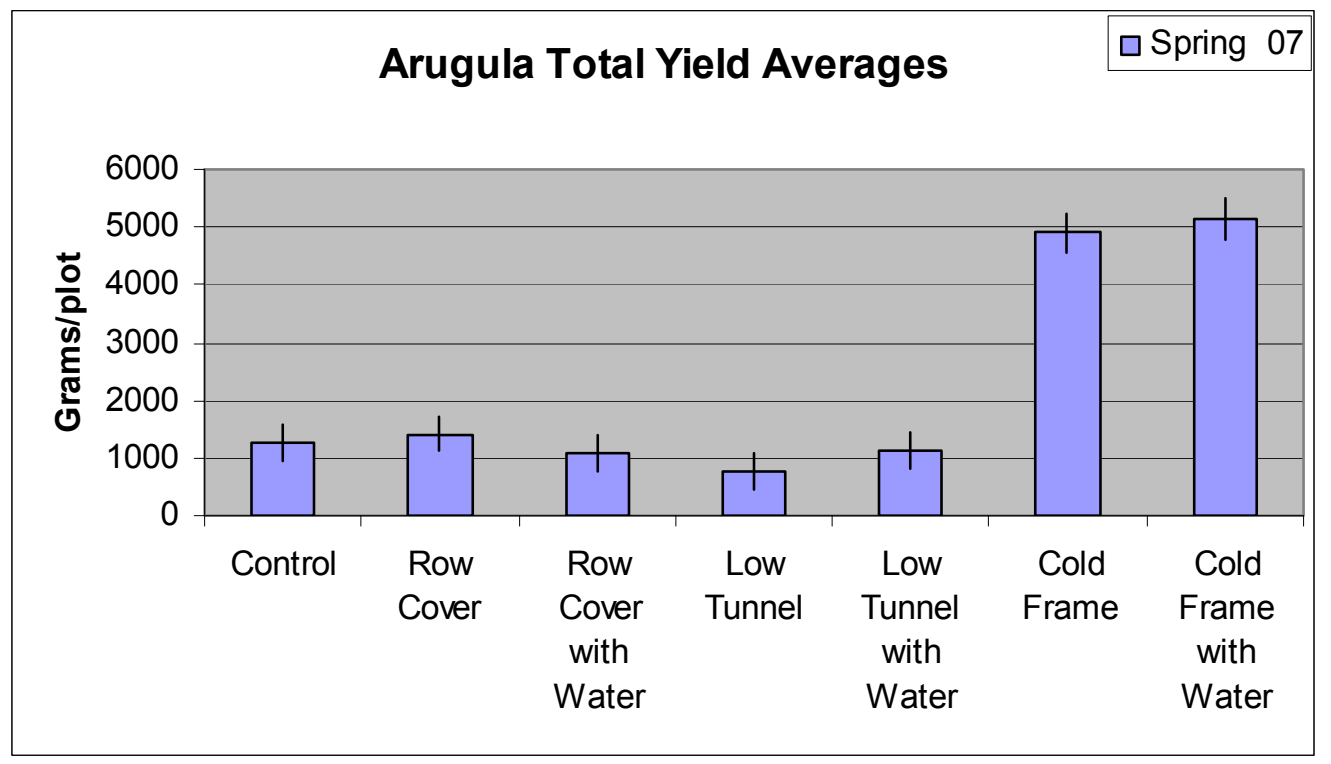

Figure 10: Combined fall and spring or spring and spring average total yields per 3.7 by $4.9 \mathrm{~m}$ plot. Error bars represent standard error.

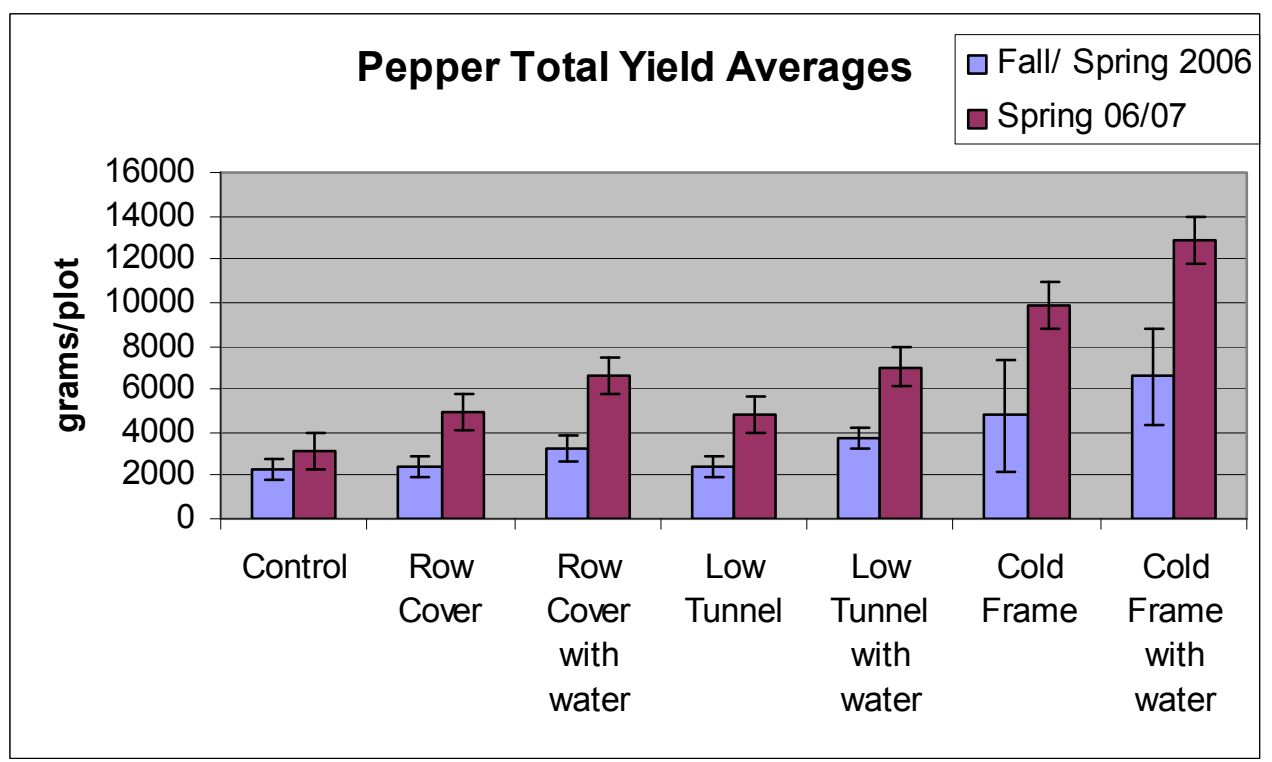


Figure 11: Combined fall and spring or spring and spring average total yields per 3.7 by $4.9 \mathrm{~m}$ plot. Error bars represent standard error.

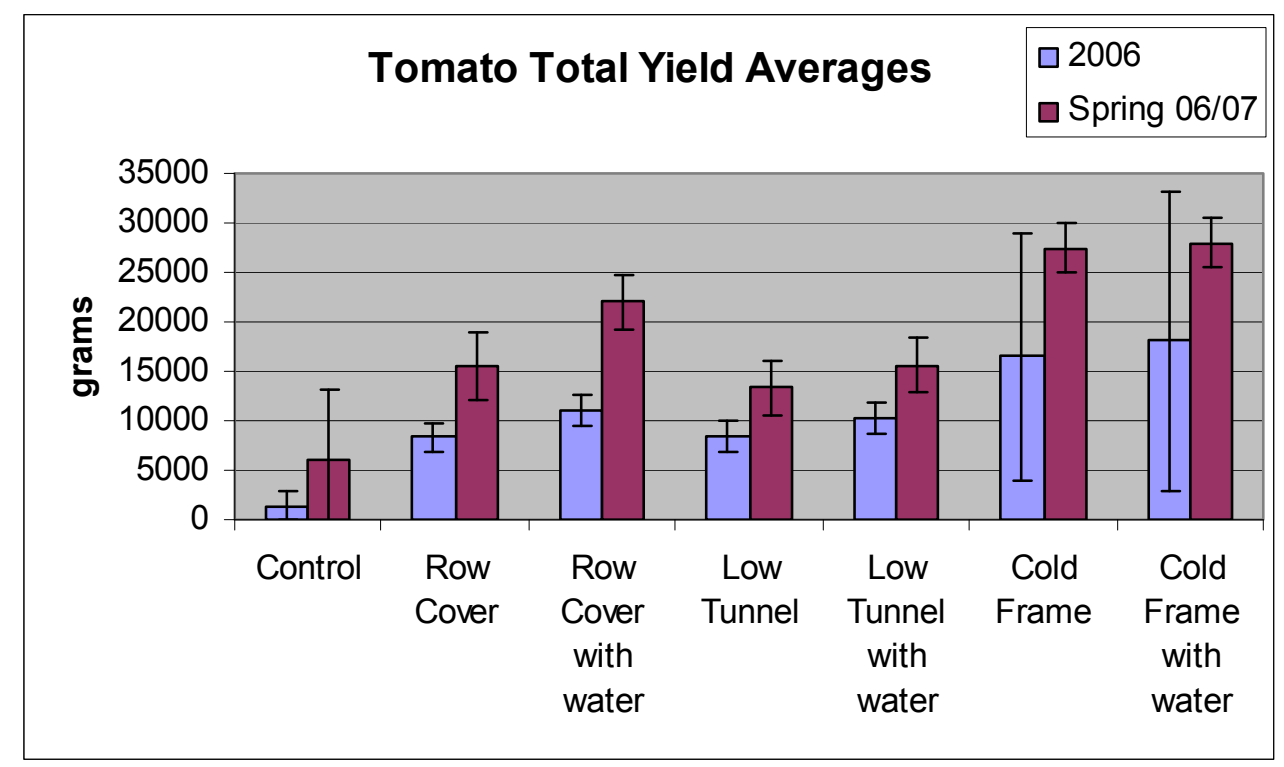

Figure 12: Combined spring and spring average total yields per 3.7 by $4.9 \mathrm{~m}$ plot. Error bars represent standard error.

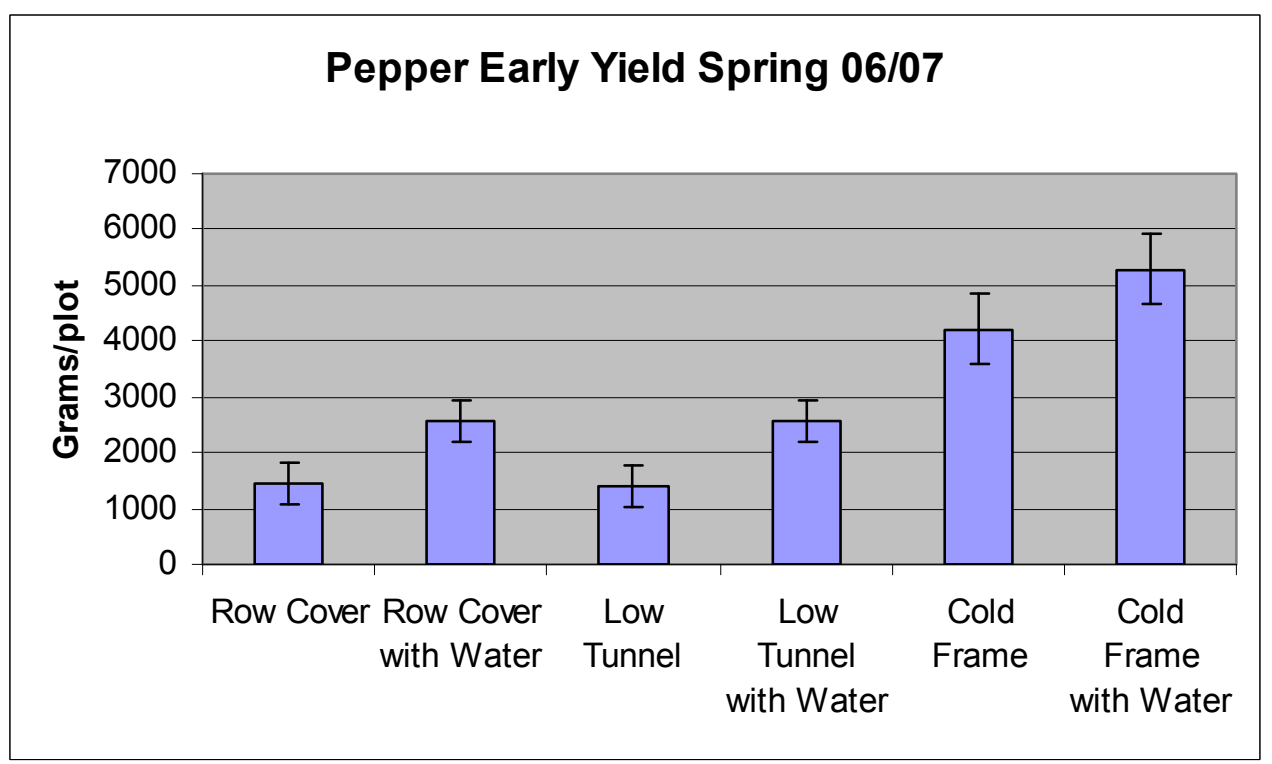


Figure 13: Combined spring and spring average total yields per 3.7 by $4.9 \mathrm{~m}$ plot. Error bars represent standard error.

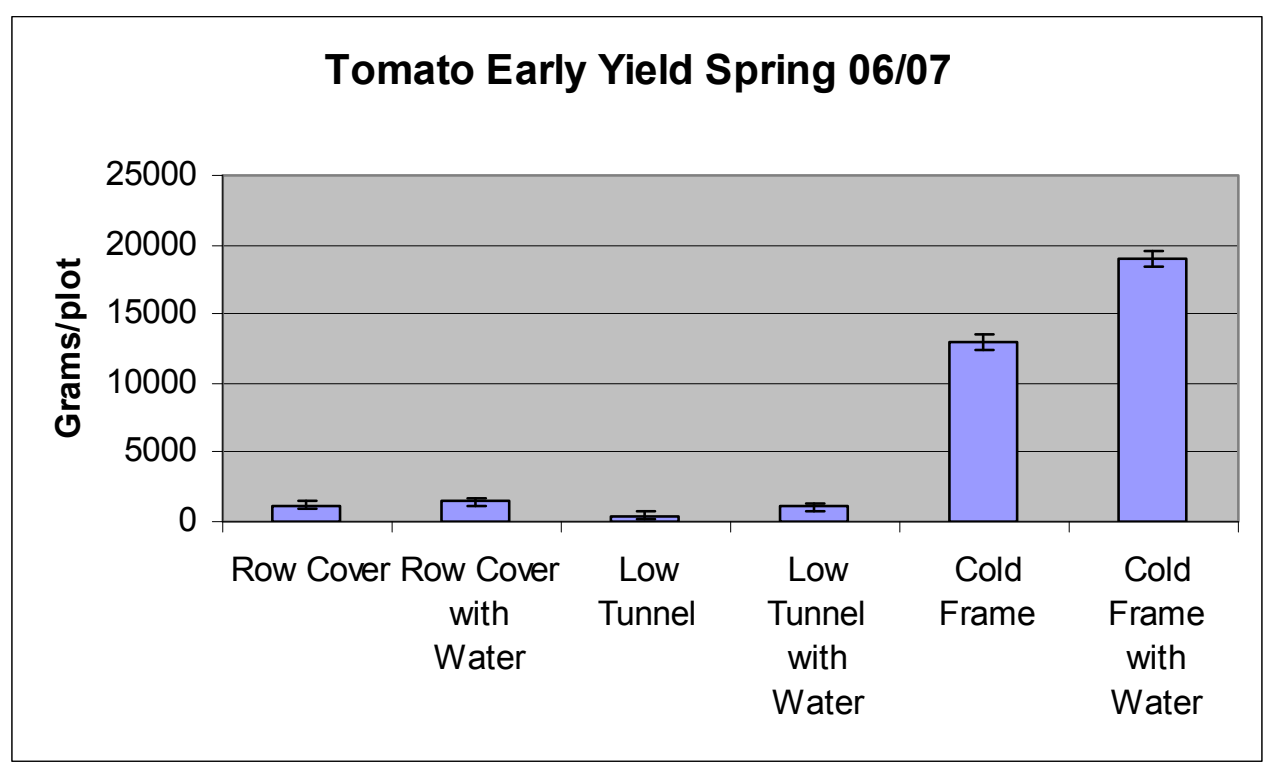




\section{Chapter 4-Discussion}

\section{Temperature:}

In the spring 2006, fall 2006, and spring 2007 analyses (Appendix B), air temperature averages showed very similar trends indicating consistent treatment effects over the course of this experiment. The higher air temperature results in this research were not unexpected and nicely corroborate other work showing increased average air and soil temperatures in high tunnels, low tunnels and row covers over control field plots. Temperature increases in high tunnels range from $1.5^{\circ} \mathrm{C}$ to $1.8^{\circ} \mathrm{C}$ in air temperatures (Cavins et al., 2000; Rader and Karlsson, 2006). Row cover air temperature increases were shown by Jenni et al. (1998) to be approximately $2{ }^{\circ} \mathrm{C}$. The same study demonstrated a 3 to $5{ }^{\circ} \mathrm{C}$ air temperature increase in perforated low tunnels. Water tubes included in non-perforated low tunnel growing environments increased air temperatures over plots without tunnels and water tubes by 6 to $8{ }^{\circ} \mathrm{C}$. Waterer (2003) showed in a comparison study that high tunnels increased the growing degree days in both the early and entire growing season over low tunnels by increasing air temperatures. These studies describe temperature increases under differing season extension techniques similar to this experiment, but because of differing climates and specific materials used direct comparisons are difficult to establish.

Although compost was used to elevate temperatures in the 2006 spring and fall seasons, air temperatures in the two cold frame treatments were statistically similar. In the spring of 2007, compost was not available in the correct time frame and these lower temperature averages show the slight, but not significant difference that compost heating may have had on the temperature averages. Clearly, the compost heating system as implemented in our experiment proved to be inadequate in its method of warm air generation and movement to significantly raise the air 
temperature in the cold frame with the water wall above the temperatures in the cold frame without water treatment.

In both years, row cover treatments showed generally higher air temperature averages than low tunnel treatments. In spring 2006, some of these differences were significant while in fall 2006 and spring 2007 only a trend towards warmer air temperatures under row cover treatments was observed. The fact that the low tunnels used perforated plastic to prevent daytime temperature excesses most likely explains these differences. The perforations used in the low tunnels increased airflow and caused lower temperatures. Peterson and Taber (1991) described the danger of row covers and low tunnels causing temperature excesses and plant damage. Slitted tunnels lower this risk of damage by season extension techniques but probably lead to the lower average temperatures we observed. Differences in specific low tunnels designs and thickness of row covers make it difficult to compare row cover and low tunnel temperature results with existing research (Jenni et al., 1998; Soltani et al., 1995). However, the work by Jenni et al. (1998) described higher average temperatures under perforated low tunnels than under spun-bonded row covers. This research suggests that row covers performed slightly better than low tunnels in elevating temperatures.

Soil temperatures followed the same patterns as air temperature for the three experimental seasons of spring 2006, fall 2006, and spring 2007 reflecting the close relationship between air and soil temperatures. Previous high tunnel research does not always agree in the description of air and soil temperatures. Rader and Karlsson (2006) discussed soil temperature increases below air temperature increases while Cavin et al. (2000) showed soil increases higher than air temperature increases. Soil temperatures, inherently more stable, tended to show fewer differences overall as compared to air temperatures in this study. Soil temperatures are more 
buffered than air temperatures because of the large soil mass and moderating influence of water in soil pores. As with air temperatures, season extension treatment soil temperatures were generally higher than field plot control treatments. Temperature increases over field plots range from $0.8{ }^{\circ} \mathrm{C}$ to $3.7^{\circ} \mathrm{C}$ in soil temperatures (Cavins et al., 2000; Rader and Karlsson, 2006) in high tunnels. Row cover soil temperature increases were shown by Jenni et al. (1998) to be around $1^{\circ} \mathrm{C}$. The same study demonstrated perforated low tunnel temperatures increased soil temperatures by 1 to $3{ }^{\circ} \mathrm{C}$. Soltani et al. (1995) recorded average soil temperatures 3 to $5{ }^{\circ} \mathrm{C}$ higher than the control for both low tunnel and row cover treatments. Water tubes included in non-perforated low tunnel growing environments increased soil temperatures by 4 to $6{ }^{\circ} \mathrm{C}$ over treatments without tunnels or water tubes (Jenni et al., 1998).

Interestingly, soil temperatures in the fall of 2006 showed higher averages than air temperatures. This difference could be attributed to slower release of heat accumulated in the soil during summer months, especially in plots employing season extension techniques. The soil body transmits heat upward toward the soil surface when air temperatures are cooler than soil temperatures, as occurs in the fall months as air temperatures decrease (NRCS,1993), thus providing a basis for observed soil temperatures warmer than air temperatures.

The soil temperature in row cover treatments tended to be higher than the low tunnels, but significant differences were not seen. The perforated low tunnels lose accumulated warm air more quickly because of increased airflow. This same trend was seen in the air temperatures discussed above. Accumulated heat in soils is released during the night time hours and this process is accelerated by the increased airflow of the perforated tunnels. This factor is likely responsible for the lower low tunnel soil temperatures than row cover soil temperatures observed in this study. 
The spring 2007 soil temperature data had an incomplete record for the control plot. For the period of time when all seven treatment averages were available, the temperature differences I observed were small. This was because of the absence of three weeks of temperature data early in the season when differences in temperature were most likely more pronounced. This conclusion is supported by the more distinct differences in soil temperature seen in the previous two seasons and by previous research showing increases in soil temperature by mulches and row covers (Aziz et al., 2001; Jenni et al., 1998).

The air and soil temperature increases seen in season extension treatments correspond well with existing research. As discussed above, Cavins (2000) and Rader (2006) showed air and soil temperature increases under cold frames and high tunnels. Studies done on row covers and low tunnels also show mean soil temperature increases using these season extension methods (Soltani et al., 1995). Jenni et al. (1998) and Aziz et al. (2001) showed that mulches and row covers significantly raise air and soil temperatures when combined with water tubes. The air and soil temperature differences observed in Jenni et al. (1998) and Aziz et al. (2001) were similar to this research, however more pronounced than what was observed in this experiment. This study used a smaller volume of water because of the $0.15 \mathrm{~m}$ diameter of the water tubes (the largest available from the supplier) where Jenni et al. (1998) used a $0.32 \mathrm{~m}$ diameter water tube. These larger diameter tubes were $8 \mathrm{~m}$ and held $250 \mathrm{~L}$ of water compared to $8 \mathrm{~m}$ of our water tubes, which contained approximately $120 \mathrm{~L}$.

In conclusion, the two years and three seasons of temperature data collected show very similar trends in air and soil temperatures when comparing different season extension technologies. Experimental treatments increased air and soil temperatures over the control in all three seasons of this study. These similarities are important because they show that the effects of 
season extension methods hold true across seasonal climactic differences. The combined analysis of both the air and soil data showed that these significant treatment effects observed were not affected by differing seasonal conditions thus providing a higher degree of confidence in the conclusions. Cold frames generally produced higher temperatures than any of the lower input methods employed. Row covers typically maintained higher air and soil temperatures than perforated low tunnels. All season extension methods tended to increase air and soil temperatures, although often low tunnels did not show significant differences in temperatures when compared to the control. The presence of water did not increase temperatures significantly, but as discussed later seem to have some influence on yields.

\section{Light:}

The purpose of gathering and analyzing data concerning photosynthetically active radiation was to determine if decreased light levels adversely affected yields in the different treatments. This information could be important because decreased light levels were an unintended result of the season extension techniques used in this experiment and could affect the overall conclusions on the use of season extension methods. Yield differences in the treatments could only be attributed to changes in light levels if the row covers, low tunnels, or high tunnels decreased the photosynthetically active radiation to levels below optimum levels for the crops while the control treatment was still exposed to optimum light levels. Typically maximum photosynthetic rates are achieved when PAR light levels are between 500 and $1000 \mu \mathrm{M} / \mathrm{m}^{2} / \mathrm{sec}$. Direct sunlight can reach radiation levels of $2000 \mu \mathrm{M} / \mathrm{m}^{2} / \mathrm{sec}$, indicating that at many times during the season an excess of light is available to crop plants (Taiz and Zeiger, 2002). 
Daily PAR averages for the two week periods in the control plot ranged from 682.4 to $770.0 \mu \mathrm{M} / \mathrm{m}^{2} / \mathrm{sec}$. These PAR levels fell well within the 500 to $1000 \mu \mathrm{M} / \mathrm{m}^{2} / \mathrm{sec}$ optimum photosynthetic range. The control treatment should therefore be able easily maintain photosynthesis during daytime hours. The row cover two-week average of $621.5 \mu \mathrm{M} / \mathrm{m}^{2} / \mathrm{sec}$, the low tunnel average of $566.0 \mu \mathrm{M} / \mathrm{m}^{2} / \mathrm{sec}$, and the cold frame average of $614.1 \mu \mathrm{M} / \mathrm{m}^{2} / \mathrm{sec}$ also clearly fell within the 500 to $1000 \mu \mathrm{M} / \mathrm{m}^{2} / \mathrm{sec}$ PAR range needed maximize photosynthesis. It can therefore be concluded that light reductions had negligible effect on the photosynthetic capacity and therefore the growth and yield of the crop plants under investigation.

\section{Total Yield:}

The total yield analysis (Appendix C) is a key factor in the economic analysis and therefore the overall profitability of the season extension techniques employed. Coupled with the early yield data, total yields demonstrate which crops respond with increased yields to season extension methods and the extent of that response. In both the spring/fall 2006 analysis and the spring 2006/07 analysis, very similar patterns were observed in overall yield data for most crops in the different treatments. Although average temperatures were higher in the spring of 2007 than in the spring of 2006, total yields showed the same increased productivity in cold frame treatments over field plot treatments. Field plot treatments with water tubes showed increased yields in peppers and similar though not significant patterns in the other crops. The only and consistently significant differences between years were observed in the total yield of the pepper crop. It can then be concluded that the effects of the experimental techniques on total yield were generally independent of yearly weather conditions. Soltani et al. (1995) and Jenni et al. (1998) 
show similar patterns of increased yields in row cover and low tunnel treatments over the control through three years of research.

The fall 2006 season showed yields much lower than the spring 2006 and 2007 seasons. In fact, the yields were so low that profitability was not reached. In West Virginia, fall temperatures drop quickly over the course of a short period of time. The September air temperature average of $18.3^{\circ} \mathrm{C}$ declines to a $7{ }^{\circ} \mathrm{C}$ average air temperature in November (NCDC, 2007). The resulting narrow window for maturation and harvest of fruit led to the dramatically low yields and quality of the fall 2006 crop. Waterer (2003) discussed this decrease in crop development brought about by low fall temperatures, which minimized the impact of fall season extension techniques in lengthening harvest times. The lower yield because of slow crop development was most pronounced in this study in the more sensitive warm season crops. Fall 2006 tomatoes yielded only $9 \%$ to $14 \%$ of spring 2006 harvest while peppers registered only $10 \%$ to $43 \%$ of spring yields.

Radish yields were not significantly different in the field plots for either spring season. The presence of water tubes also did not result in increased yields in radishes. Lettuce follows this same pattern and the only difference that can be seen is a significantly lower control than the field plot treatments in the spring $06 / 07$ orthogonal contrasts. Lower control yields were due to herbivory by rodents. Season extension methods showed increased yields over the control by physically protecting the crop from damage. These cool season crops used in our study need lower minimum temperatures (Decoteau, 2000) and fewer accumulated heat units for optimum growth and productivity. The lack of significant yield increases in the experimental field plots are therefore most likely because of the fact that cool season crops are less sensitive to the small temperature increases observed in the experimental treatments. The experimental field plots 
were however harvested earlier due to the temperature buffer provided by the season extension techniques. Most of this earliness can be attributed to the earlier planting date afforded by the season extension techniques. Since we could not command price premiums for cool season crops, these earlier harvests, at least in our markets, are not especially desirable. However, earlier harvests and sales could lead to increased customer loyalty and a prolonged market season that could still benefit a grower in overall economic profitability.

The only differences observed in the total yields of the cool season crops were between the field plots and the cold frames. For the lettuce, radish, and arugula, differences were seen in both analyses, spring/fall 2006 and spring 06/07, between the field plots and the cold frames. Both analyses showed that total yields were higher for all three crops in the two cold frames compared to the field plot treatments. Research on cool crop production in cold frames is not as readily available as studies on warm season crops, such as tomatoes and melons. In addition, the work that has been reported on the use of cold frames for cool season production is equivocal. Rader and Karlsson (2006) showed that lettuce yields were sometimes higher in field plots and sometimes higher in high tunnels. Other research with shade-covered high tunnels has shown increased summer lettuce yields over field production (Kelly, 2005). The potential for higher yields and increased profitability in cool season crops in cold frames or high tunnels therefore deserves further investigation.

The warm season crops showed very different results. In both the fall/spring 2006 and the spring $06 / 07$ analyses, the tomato and pepper total yields were significantly different among field plots. The control showed lower yields than the row cover and low tunnel treatments for both crops. Higher productivity of warm season crops under row covers and in low tunnel has been reported previously. Marr et al. (1991) reported higher early and total yields in 
watermelons because of the use of row covers in the first month on the growing season. Peterson and Taber (1991) also showed the potential for increased tomato yield under low tunnels if excessively high temperatures were avoided.

In this study, pepper total yields were higher in treatments with water tubes in the field plots in both the spring/fall $2006(0.03)$ and spring 06/07 (0.022) analyses. The spring 06/07 analysis showed that tomato total yields were higher at the 0.10 level when water tubes were added to the growing environment of the field plots. Increases in warm season crop growth and production have been demonstrated in other studies. Early and total yield of muskmelons was shown to increase with the use of water tubes and various mulches and row covers (Jenni et al., 1998). Aziz et al. (2001) recorded air and soil temperatures that were rarely different between perforated low tunnels with water tubes and tunnels without water tubes while showing generally higher early relative growth rates, and dry weight in tunnels with water tubes. Interestingly, a similar lack of consistent air and soil temperature increases was shown with increased yield in this study. The growth differences attributed to the addition of water are therefore more related to a moderation of temperatures than to discernable increases in average temperatures. These two observations of decreased air temperature fluctuations and increased growth measures influenced by the inclusion of water tubes were also important conclusions of previous research (Aziz et al., 2001).

Yield increases were also clearly seen in the cold frames in the warm season crops of tomatoes and peppers. Corroborating of these findings, Waterer (2003) showed that high tunnels consistently produced more mature and marketable fruit than low tunnels in warm season crops over three spring seasons. These crops are commonly grown in cold frames and high tunnels because of their higher market value (Wells and Loy, 1993). The profitability of these systems 
has been previously researched for the production of warm season crops (Coltrain and Jett, 2007; Waterer, 2003).

Taken together, the conclusion is reached that the production of warm season crops, tomatoes and peppers, respond well to a number of season extensions technologies in terms of overall yields. The highest yields are generally found in the higher input cold frames or high tunnels. However, lower input season extension methods, such as row covers and low tunnels, can increase yield over controls and in some instances rival yields of cold frames. Additionally, analysis of pepper yields showed the addition of water to growing environments as a temperature-moderating tool can significantly raise the overall productivity of this warm season crop.

\section{Regression Analysis:}

The purpose of performing a regression analysis was to determine the relationship between the total yield and average air and soil temperatures (Appendix D). The increase in yield observed by employing season techniques was assumed to be related to the increase in temperature as light was determined to not significantly impact yields. Regression analysis determined to what extent soil and air temperatures impact total yields.

Average temperatures in the early portion of the season when low tunnels and row covers were in place (early April through early June) were compared with total yield. It was assumed that the influence of season extension methods on increased temperatures is most noticeable in the April and May time period after cooler spring temperatures and before heat excesses can occur under the covers. In support of this assumption, Aziz et al. (2001) reported that the rates of muskmelon growth under row covers and tunnels soon after planting were increased in 
mulched mini-tunnels. Avilla et al. (1997) also showed that pepper marketable yields under row covers were greatest when covers were applied directly after planting. This increased yield in peppers demonstrates the effect of increased early growth promotion by row covers on marketable yields.

Overall, there was a positive relationship with total yield in all crops for both air and soil temperatures in the spring $06 / 07$ and fall 2006 seasons. This is primarily because of the increase in heat units or growing degree-days provided by season extension technologies (Waterer, 2003). Cool season crops of lettuce, radish, and arugula typically displayed lower $\mathrm{R}^{2}$ values and estimates of yield gains than the warm season crops of tomato and peppers. The higher sensitivity of warm season crops to low temperatures than cool season crops is the most likely factor influencing this observation (Decoteau, 2000). However, as far as can be ascertained, no other studies are available that compare the temperature effects through regression analysis of season extension methods for warm or cool season crops.

Fall season $\mathrm{R}^{2}$ values for all crops were higher than spring season values. No other regression analyses could be found with which to compare this data. However, it should be noted that the 2006 and 2007 spring season temperature records were more complete and reliable than the fall 2006 season analyzed alone. For nearly all crops in both seasonal analyses, the soil temperature $\mathrm{R}^{2}$ values were higher than the air temperature values. As could be seen from the temperature averages, the soil temperature did not fluctuate as much as air temperature because of the soil volume and moisture level that buffered temperature changes. This lesser degree of fluctuation is very likely responsible for the greater $\mathrm{R}^{2}$ values seen in the soil temperature regression analysis. The collection of soil temperature data has the potential to be more closely related to increases in yield than the more fluctuating air temperatures. The effect of soil 
temperature on yield is discussed in field crop production guidelines where the negative effect of low soil temperatures on corn yields is used as a factor in determining tillage methods (Roth, 1996).

\section{Early Yield:}

As growers operate in a crowed market, producing quality early produce could be a key way to increase market share and profitability. Capturing these early price premiums and customers, the main advantage of selling a crop slightly earlier in the season than normal, could therefore be worthwhile (UK, 2007). To gather yield data in support of this benefit, early yields were measured.

Early yield differences were only shown in the context of the two spring seasons of 2006 and 2007 (Appendix E) in this study because of the difficulties in comparing fall with spring data. Spring early yields were collected over a period of four to six weeks before the control plots were harvested. Increased minimum temperatures of the season extension techniques allowed planting only two to four weeks (see Appendix G) before the control showing the more rapid development of plants and maturation of fruit in the season extension treatments.

Fall late yields were primarily immature and occurred only in the row cover and cold frame treatments. The rapid drop in fall temperatures mentioned above killed the control and low tunnel treatments in one night (Oct. $\left.13^{\text {th }}, 2006\right)$ and drastically slowed the development of the crops in the row cover and cold frame treatments. This crop loss virtually eliminated the late yields in the treatment groups. Other research has discussed similar decreased fall growth and maturation rates and their negative impact on harvestable product (Waterer, 2003). 
In the comparison of early yield differences in the spring of 2006 and 2007, only warm season crops were used. The temperature increases provided by the season extension techniques allowed earlier planting time for both warm and cool season crops as discussed above. Lettuce, radish, and arugula yields were measured after one destructive harvest. Because of the differing planting times, the cool crops grown under season extension treatments were all harvested before the control crops; therefore the entire yield was early. Differences in these yields were therefore discussed in the total yield section (see above). Tomatoes and peppers were harvested over a series of weeks and allowed early season yield differences to be clearly measured. Previous research has focused on early growth and yields primarily as related to warm season crops that allowed for multiple harvests and more easily definable early yields (Aziz et al., 2001; Jenni et al., 1998; Reiners and Nitzsche, 1993).

Early yields influenced by the season extension techniques carried throughout the season and resulted in higher overall yields for tomatoes and peppers. Simply, treatments with higher early yields tended to have higher total yields. Treatment differences in early yield could be readily observed in pepper and tomato. The most striking difference seen in early yield was between the cold frame and the field plot treatments. The early yields from both the cold frame treatments were significantly higher than all of the field plots showing the benefits of larger protected structures in increasing early yields. This increase in earliness and quantity of yield is an often cited supporting factor for the introduction of high tunnels or cold frames into growing systems (Bachman, 2005). No differences in early yield between the two cold frames treatments could be observed suggesting that water walls and composting systems and the earlier planting dates they allow may not significantly contribute to early yields. 
The differences in pepper early yield between the row cover and low tunnel treatments with and without water tubes correspond with the impact of water inclusion in the total yield data for peppers. This increased early growth in warm season crops because of temperature increases aided by water tubes was corroborated by Jenni et al. (1998) and Aziz et al. (2001) when increased relative growth rates and early yield was seen in treatments with water tubes. Differences $(<0.0001)$ were also seen in the pepper early yields between years, a pattern similar to observations made for total yields with 2007 yields being higher than 2006 yields. 2006 air and soil temperatures showed generally lower averages than 2007. Clearly, peppers respond more measurably to climatic and treatment differences than do the other crops in this experiment. Peppers are a warm season crop that requires even higher temperatures than tomatoes for optimum growth and productivity. Peppers respond poorly to extreme temperatures and will not set fruit below $16^{\circ} \mathrm{C}$ night time temperature (Decoteau, 2000). This research suggests that the effects of season extension techniques and their temperature moderating influence are magnified on this temperature sensitive crop.

Differences between the spring 2006 and spring 2007 seasons $(<0.0001)$ similar to the observations made for peppers were also seen in the early yield of tomatoes, but unlike the pepper crop not in the total yields. Again this indicates the unpredictable nature of early yields. Peterson and Taber (1991) discuss these less certain early yields, which have the potential to be lower than the control yields when high temperatures cause flower abortion and retard early fruiting. 2006 early yields were higher than 2007 in tomatoes in a reversal of the pepper early yield averages. A key difference seen in the tomato early yields was a treatment*year interaction. These interactions show the sensitive nature of early yields to differing temperatures and treatments early in the growing season. Water can act as a buffer against these fluctuations 
and aid in temperature stabilization in addition to decreasing the possibility of chilling injury to sensitive plants by early season low temperatures (Jenni et al., 1998).

\section{Economic Analysis:}

The purpose of employing season extension technologies is to enhance both productivity and profitability for vegetable growers. Studies have repeatedly shown the potential for increasing early and total yield in many vegetable crops by using row covers, mulches, low tunnels, and cold frames or high tunnels (Jenni et al., 1998; Marr et al., 1991; Reiners and Nitzsche, 1993; Waterer, 2003). These improvements in the yield and length of season are not relevant if the potential to increase profits does not exist. The costs calculated here are in addition to costs incurred for the control and are not the costs for the entire market garden operation. The purpose then of this economic analysis is to determine if the additional time and materials used are offset by the increases in yield at a minimum and to determine the potential for increased profitability.

The spring 2006 and spring 2007 seasons only were used in this comparison because fall yields were insignificant and many of the fruits immature. No marketable yields and therefore profits were achieved in the fall season for the warm season crops. The $18 \mathrm{~m}^{2}$ experimental plots that were used for all treatments filled only half of the growing area of the cold frames. The cost of the cold frame without water treatment was therefore calculated based on half the cost of the structure and materials. The cold frame with water and compost treatment took up the whole 6 $\mathrm{m} \times 7.7 \mathrm{~m}$ structure to produce $3.7 \mathrm{~m} \times 4.9 \mathrm{~m}$ of growing space so the construction costs of this treatment were more than double the regular cold frame. 
This experiment was designed to cover a range of crop plants including cool and warm season vegetables. The vegetables and species chosen were not intended to maximize profits in the space available, but to gain broader knowledge on the effects of season extension techniques on a variety of crops. Simply speaking, growers seeking to profit from crop production would likely grow a different crop mix designed to maximize profit. The early season and regular season prices are the same for most crops with the exception of tomatoes, which can more easily attain a price premium in our market than any of the other crops produced. This absence of price premiums for most early season produce means that total yields play a larger role in overall profits than it would if early prices were higher. The prices used were actually obtained from this produce at our local market and represent possible profits in this economic analysis. Because of differences in market conditions and selling price for each grower, this is an economic analysis only representative of increases in profitability gained by using season extension techniques.

In spring 2006, the four crops that were grown showed potential returns per plot (18 $\mathrm{m}^{2}$ of growing area) between $\$ 82.89$ for the control and $\$ 328.93$ for the cold frame with water. Similar patterns were seen in the potential profits from the 2007 spring season. Potential profits were higher overall, because of the elevated temperatures and increased warm season yields along with the addition of the arugula crop. Again the control plot showed the lowest potential economic return (\$97.55) while the cold frame with water treatment had the highest (\$344.01.) These numbers are an interesting indicator of potential returns, but are not useful unless the time and additional input costs of the season extension technologies are subtracted from the potential returns. 
In 2006, the control plot showed the lowest potential profit (\$82.89) as all experimental treatments covered their additional input costs with increased yield. The highest potential returns were seen in the cold frame without water $(\$ 200.87)$ and the row cover and low tunnel treatments with water. The 2007 spring season showed similar trends. The control again had the lowest potential profit (\$97.55) and the cold frame without water treatment the highest (\$232.19.) Field plot treatments with water were also more profitable than their counterparts without water tubes.

Several potentially important conclusions can be drawn from this economic data. The first and likely central theme is that all experimental treatments increased the potential return over the control treatment in both years. This shows that not only do season extension technologies have the ability to increase yield, they are also generally cost efficient and can increase overall profitability.

The second conclusion that can be drawn is that water in the growing environment can indeed aid potential profits when used appropriately. In each of the years in all field plot treatments, the row cover with water and low tunnel with water treatments showed increased potential profits over their counterparts lacking water tubes in the growing environment. If water can be added as a temperature buffer in an efficient manner, the potential exists to raise profits. This potential for an increase in profits was not seen in the more labor and cost intensive cold frame with water wall treatment.

Thirdly, we can look at the comparison between the field plots and the more costly cold frame treatments. In both years, we saw the cold frame without water treatment yield the highest potential net returns and exceed the field plots with water tubes. These findings are confirmed by the economic analysis of Waterer (2003), which showed increased returns per meter of row 
with high tunnels over low tunnel field plots. The cold frame with water treatment did not use space efficiently and was therefore less profitable. However, returns from all season extension techniques exceeded the control, and lower input techniques could be viable alternatives to higher input methods, especially when growers lack the capital to invest in higher input techniques such as high tunnels. 


\section{Chapter 5-Conclusions}

The conclusions for this research project should be examined in the light of the objectives discussed in the introduction. The first objective was to determine the influence of the six season extension methods on air and soil temperatures and early and total yield in selected vegetable crops. Significant air and soil temperature differences were seen in all seasons between the control and the experimental treatments. Based on these observations, all of the methods employed in this study could be considered as potentially useful season extension technologies. However, higher temperatures were seen in the cold frame treatments, followed by the row covers and low tunnel treatments, which in some cases showed air and soil temperatures indistinguishable from the control. This leads to the conclusion that cold frames and possibly row covers are the most useful methods in altering the microclimate. Total and early yields were increased by all season extension techniques. Warm season crops showed more significant increases in all treatments. However, cold frames significantly improved the earliness and overall yield of the warm and cool season crops by the largest margin in both years. Cold frames, or high tunnels, without considering cost, are therefore one of the best ways for growers to increase temperatures and early and total yield in their vegetable crops.

The second objective was to determine the effect of the inclusion of water in the growing environment on temperature and yield. Significant increases of air and soil temperatures in the treatments that included water tubes or water in bottles was rare. Water differences were more apparent in yields than in absolute temperatures increases. Yield increases are therefore, most likely, more attributable to temperature moderation than absolute increases in average temperatures or minimum temperatures. The inclusion of water in the growing environment tended to increase yields in all crops. However, changes in cool season crop yields did not rise to 
the level of statistical significance. Peppers were the most sensitive crop and significant yield increases were seen in both years with the addition of water as a temperature-moderating medium. The addition of water as a temperature buffer without regard to cost or microclimate changes as measured in this research is therefore highly recommended for any season extension technique to improve overall and early yields in warm season crops.

The third objective was to determine the economic feasibility of the season extension techniques employed in this study. Economic analyses showed that all of these season extension techniques have the possibility of raising returns and profits for growers. The ultimate decision on what techniques to use depends on the level of investment a grower can make and local market conditions. Lower cost methods, such as low tunnels and row covers can enhance yields and profits, especially with the inclusion of a water buffer, but cold frames show the greatest potential for economic returns and profits. Although the use of a water wall and a composting system in the cold frame could raise temperatures, the investment and loss of space were detrimental to the economics of such a system. In short, the highest returns and profits can be made with unaltered cold frames, especially for the production of warm season crops. However, if cold frames or high tunnels prove too great of an initial investment, row covers especially incorporating a water buffer can be considered the next best choice or even the first choice for cool season crops with small profit margins.

The fourth and final objective was the development of a season extension decision making tool (Appendix G). This model combines the average minimum temperature increases in a number of season extension technologies over the two years of data collection in this work with long-term frost/freeze data. The levels of temperature protection from freezing temperatures observed ranged from $0.2^{\circ} \mathrm{C}$ to $2.9^{\circ} \mathrm{C}\left(0.4^{\circ} \mathrm{F}\right.$ to $\left.5.2^{\circ} \mathrm{F}\right)$ for season extension techniques. 
Incorporating these expected temperature increases with long-term NCDC predictions (Appendix F) and local short-term forecasts resulted in a tool that allows growers to make sound planting date decisions.

Growers have a variety of choices to enhance the quantity of their yields to capture enhanced profits and markets. The methods employed in this research show great potential for growers at all levels with varying amounts of resources to invest. Water inclusion in growing environments shows potential to increase the earliness and overall yields of vegetables, especially warm season crops. Further work on making such systems more accessible and affordable for growers could significantly influence profits. By integrating such techniques, local market growers could make steps toward capturing markets that have been increasingly controlled by distant producers. These gains would produce benefits for growers and society in the overall sustainability of our agricultural sector. 


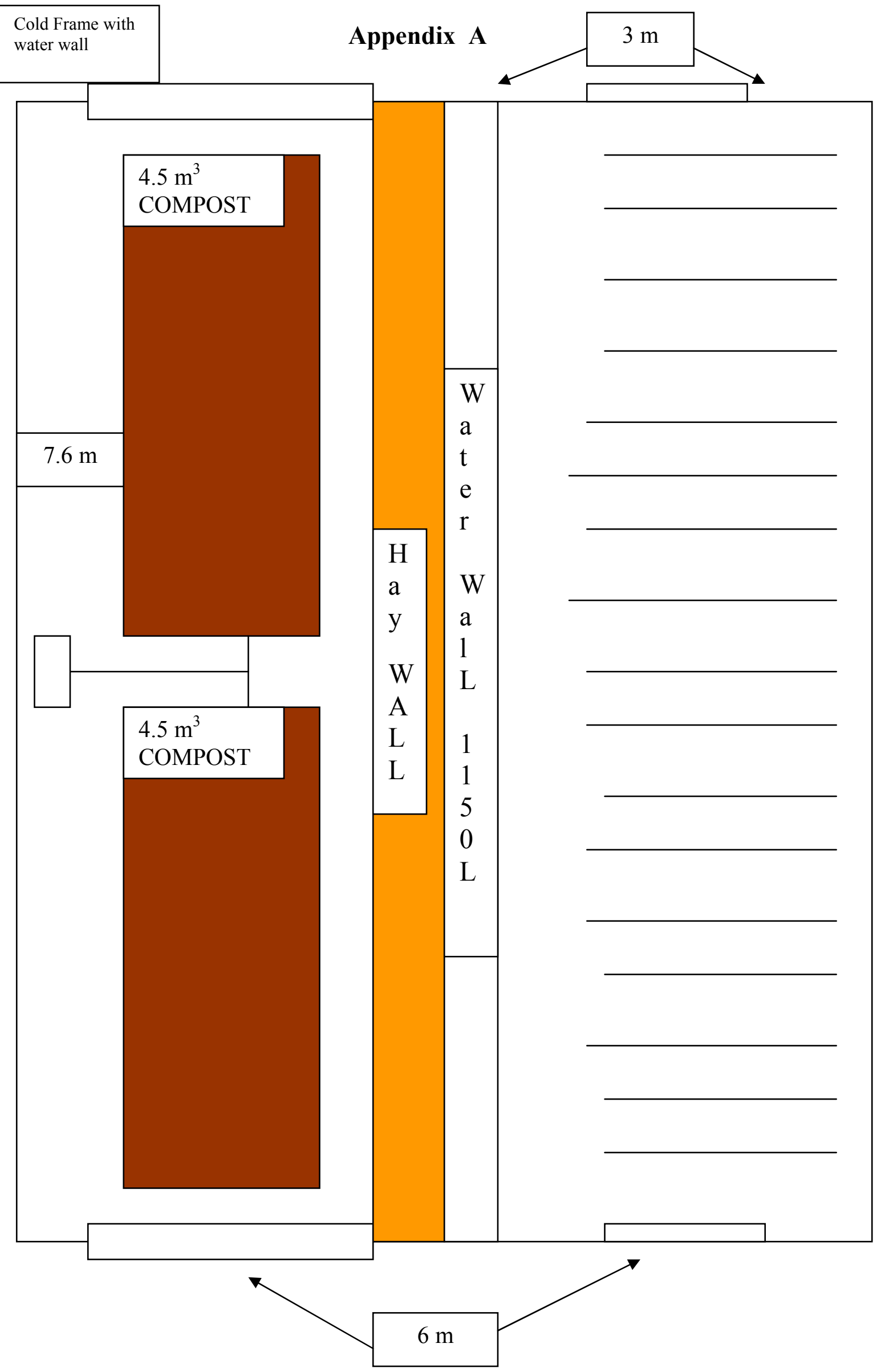




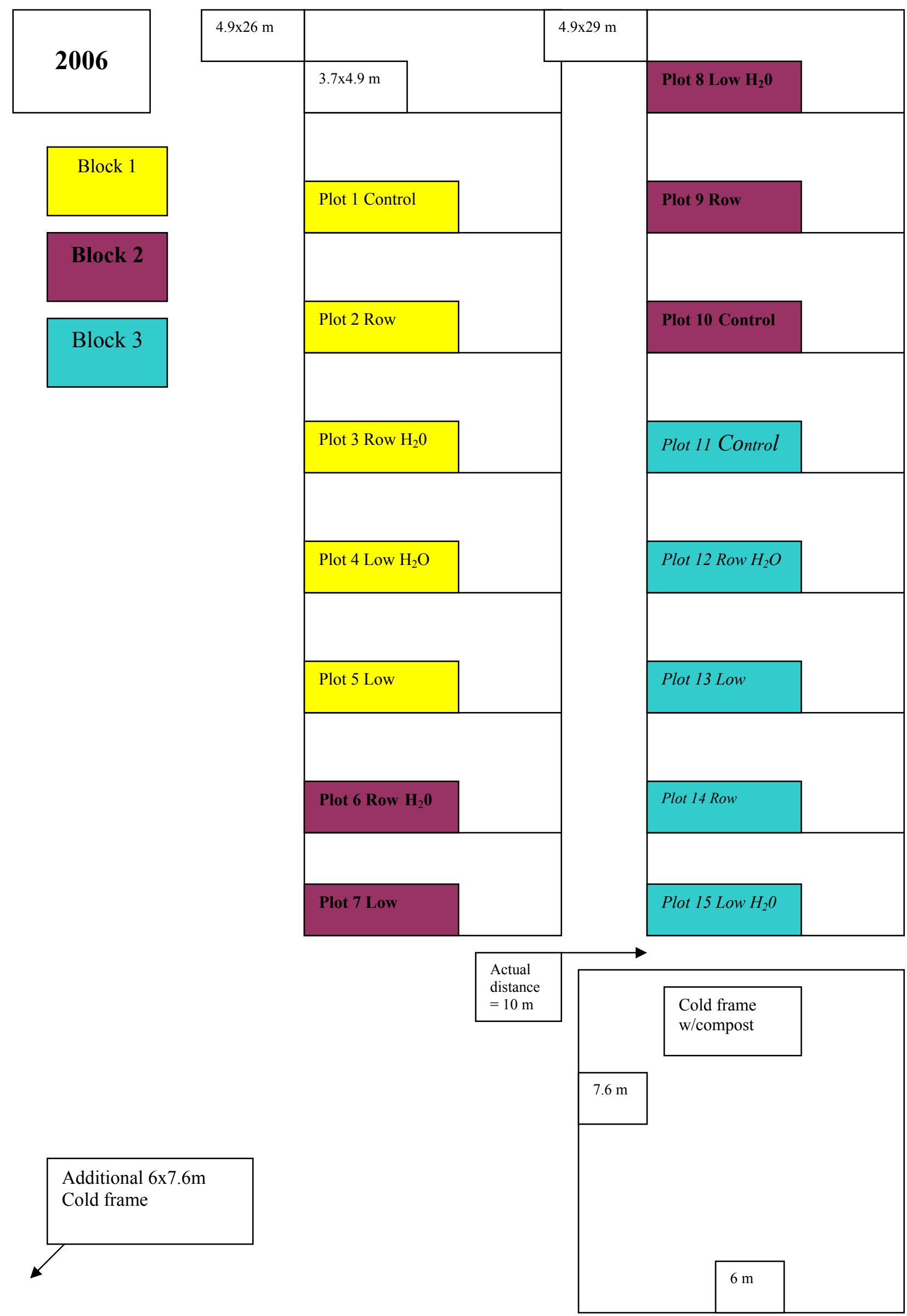




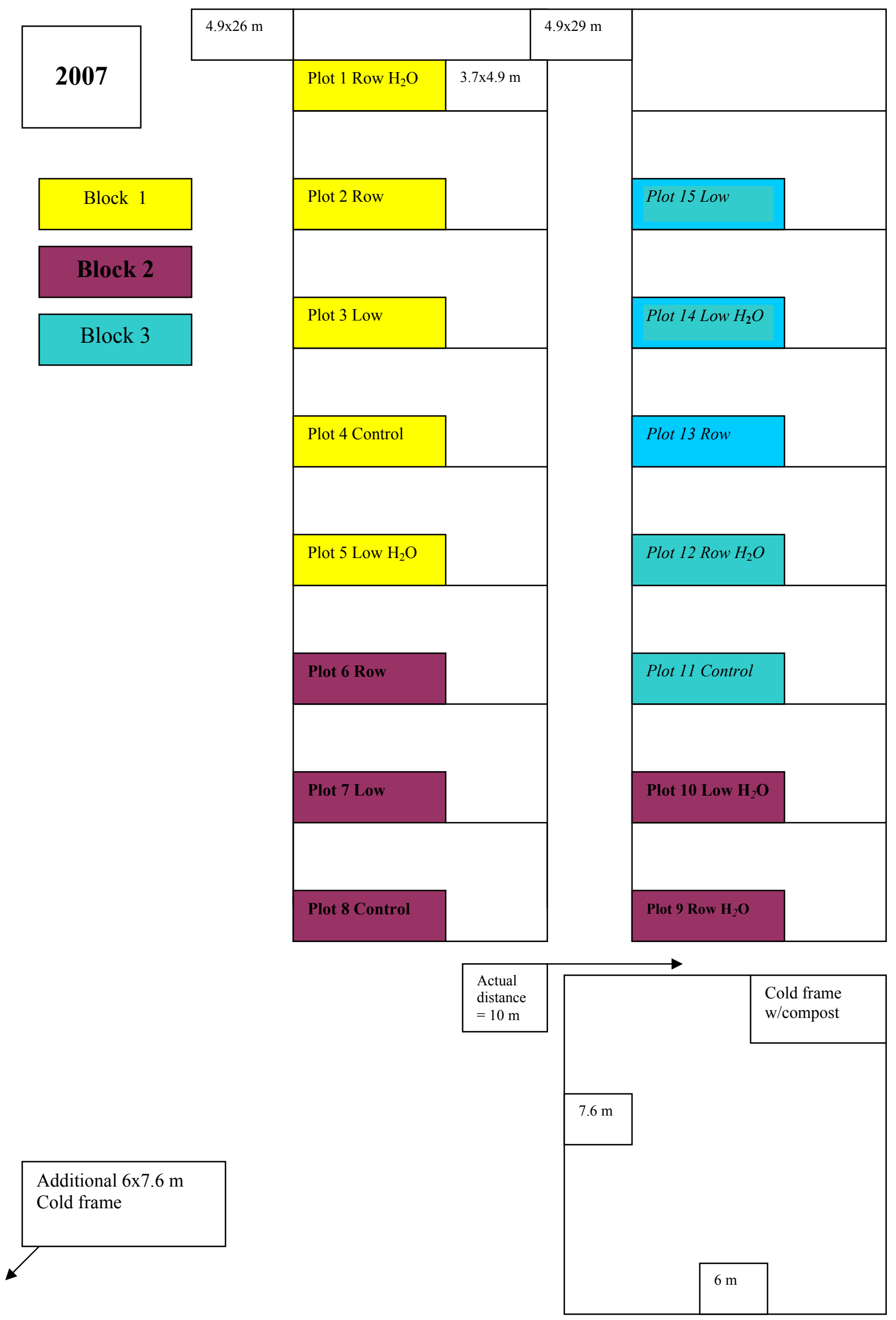




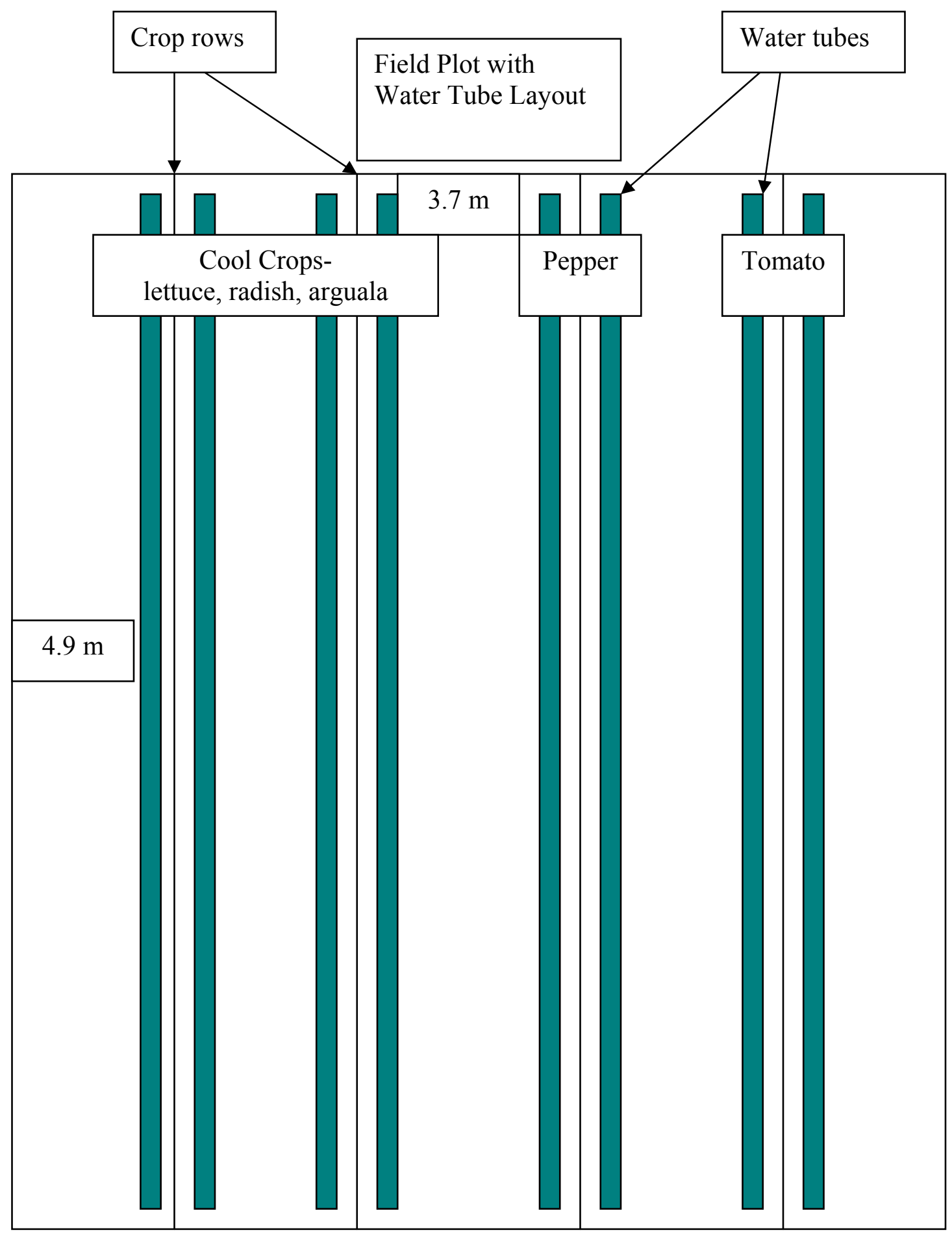




\section{Appendix B- Temperature Analyses}

GLM Procedure

\begin{tabular}{|l|l|l|l|l|l|}
\hline Season & & & DF & F value & P value \\
\hline Spring 2006 & Air & Treatment effect & 6 & 9.13 & $<0.0001$ \\
\hline $\mathrm{N}=73$ & & Control vs. others contrast & 1 & 28.92 & $<0.0001$ \\
\hline & Soil & Treatment effect & 6 & 17.64 & $<0.0001$ \\
\hline & & Control vs. others contrast & 1 & 17.08 & $<0.0001$ \\
\hline Fall 2006 & Air & Treatment effect & 6 & 3.26 & 0.0043 \\
\hline $\mathrm{N}=34$ & & Control vs. others contrast & 1 & 8.01 & 0.0051 \\
\hline & Soil & Treatment effect & 6 & 7.89 & $<0.0001$ \\
\hline & & Control vs. others contrast & 1 & 16.97 & $<0.0001$ \\
\hline Spring 2007 & Air & Treatment effect & 6 & 1.77 & 0.10 \\
\hline $\mathrm{N}=63$ and 42 & & Control vs. others contrast & 1 & 6.16 & 0.014 \\
\hline & Soil & Treatment effect & 6 & 3.82 & 0.001 \\
\hline & & Control vs. others contrast & 1 & 10.62 & 0.0012 \\
\hline
\end{tabular}

Treatment $*$ Season Interaction

\begin{tabular}{|l|l|l|l|}
\hline & DF & F value & P value \\
\hline Air & 6 & 0.10 & 0.99 \\
\hline Soil & 6 & 1.23 & 0.29 \\
\hline
\end{tabular}




\section{Appendix C- Total Yield Analyses}

2006 Spring and Fall Total Yield Analyses for Field Plots- GLM fit for an ANOVA of a randomized complete block design

Lettuce
\begin{tabular}{|l|l|l|l|}
\hline Source & DF & F Ratio & Probability \\
\hline Block & 2 & 1.78 & 0.20 \\
\hline Treatment & 4 & 0.70 & 0.60 \\
\hline Season & 1 & 114.19 & $<0.0001$ \\
\hline Trt*Season & 4 & 0.73 & 0.58 \\
\hline Row vs. Low & 1 & 0.05 & 0.82 \\
\hline $\mathrm{H}_{2} \mathrm{O}$ & 1 & 0.51 & 0.48 \\
\hline
\end{tabular}

\section{Radish}

\begin{tabular}{|l|l|l|l|}
\hline Source & DF & F Ratio & Probability \\
\hline Block & 2 & 2.40 & 0.11 \\
\hline Treatment & 4 & 1.01 & 0.43 \\
\hline Season & 1 & 13.55 & 0.0017 \\
\hline Trt*Season & 4 & 0.84 & 0.52 \\
\hline Row vs. Low & 1 & 0.90 & 0.36 \\
\hline $\mathrm{H}_{2} \mathrm{O}$ & 1 & 2.52 & 0.13 \\
\hline
\end{tabular}

Pepper
\begin{tabular}{|l|l|l|l|}
\hline Source & DF & F Ratio & Probability \\
\hline Block & 2 & 0.82 & 0.46 \\
\hline Treatment & 4 & 2.34 & 0.097 \\
\hline Season & 1 & 78.55 & $<0.0001$ \\
\hline Trt*Season & 4 & 0.82 & 0.53 \\
\hline Row vs. Low & 1 & 3.22 & 0.084 \\
\hline $\mathrm{H}_{2} \mathrm{O}$ & 1 & 5.20 & 0.030 \\
\hline
\end{tabular}

Tomato
\begin{tabular}{|l|l|l|l|}
\hline Source & DF & F Ratio & Probability \\
\hline Block & 2 & 1.50 & 0.25 \\
\hline Treatment & 4 & 6.61 & 0.0019 \\
\hline Season & 1 & 91.69 & $<0.0001$ \\
\hline Trt* Season & 4 & 4.64 & 0.0094 \\
\hline Row vs. Low & 1 & 0.11 & 0.75 \\
\hline $\mathrm{H}_{2} \mathrm{O}$ & 1 & 0.36 & 0.55 \\
\hline
\end{tabular}


2006/2007 Spring Analyses for Field Plots- ANOVA and orthogonal contrasts

Lettuce

\begin{tabular}{|l|l|l|l|}
\hline Source & DF & F Ratio & Probability \\
\hline Block & 2 & 0.78 & 0.48 \\
\hline Treatment & 4 & 1.75 & 0.18 \\
\hline Year & 1 & 0.99 & 0.33 \\
\hline Trt*Year & 4 & 1.24 & 0.33 \\
\hline Row vs. Low contrast (t ratio) & & 0.31 & 0.76 \\
\hline Water tubes vs. without contrast (t ratio) & & 2.18 & 0.042 \\
\hline Control vs. Others contrast (t ratio) & & 1.20 & 0.24 \\
\hline
\end{tabular}

Radish

\begin{tabular}{|l|l|l|l|}
\hline Source & DF & F Ratio & Probability \\
\hline Block & 2 & 2.45 & 0.11 \\
\hline Treatment & 4 & 1.56 & 0.23 \\
\hline Year & 1 & 2.53 & 0.13 \\
\hline Trt*Year & 4 & 0.39 & 0.81 \\
\hline Row vs. Low contrast (t ratio) & & -0.42 & 0.68 \\
\hline Water tubes vs. without contrast (t ratio) & & 1.21 & 0.24 \\
\hline Control vs. Others contrast (t ratio) & & 1.96 & 0.065 \\
\hline
\end{tabular}

Arugula
\begin{tabular}{|l|l|l|l|}
\hline Source & DF & F Ratio & Probability \\
\hline Block & 2 & 1.82 & 0.22 \\
\hline Treatment & 4 & 0.60 & 0.67 \\
\hline Row vs. Low contrast (t ratio) & & 0.40 & 0.70 \\
\hline Water tubes vs. without contrast (t ratio) & & 1.48 & 0.18 \\
\hline Control vs. Others contrast (t ratio) & & 1.45 & 0.19 \\
\hline
\end{tabular}

Pepper
\begin{tabular}{|l|l|l|l|}
\hline Source & DF & F Ratio & Probability \\
\hline Block & 2 & 0.93 & 0.41 \\
\hline Treatment & 4 & 3.38 & 0.032 \\
\hline Year & 1 & 4.46 & 0.049 \\
\hline Trt*Year & 4 & 1.82 & 0.17 \\
\hline Row vs. Low contrast (t ratio) & & -0.40 & 0.69 \\
\hline Water tubes vs. without contrast (t ratio) & & 2.50 & 0.022 \\
\hline Control vs. Others contrast (t ratio) & & 3.14 & 0.0057 \\
\hline
\end{tabular}


Tomato

\begin{tabular}{|l|l|l|l|}
\hline Source & DF & F Ratio & Probability \\
\hline Block & 2 & 0.65 & 0.53 \\
\hline Treatment & 4 & 2.95 & 0.046 \\
\hline Year & 1 & 0.009 & 0.92 \\
\hline Trt*Year & 4 & 2.59 & 0.12 \\
\hline Row vs. Low contrast (t ratio) & & 1.75 & 0.096 \\
\hline Water tubes vs. without contrast (t ratio) & & 1.77 & 0.093 \\
\hline Control vs. Others contrast (t ratio) & & 3.85 & 0.0012 \\
\hline
\end{tabular}

Confidence Intervals for Cold Frame Total Yield Comparisons with Field Plots

\begin{tabular}{|c|c|c|c|c|c|c|c|c|c|c|}
\hline \multirow[t]{2}{*}{ Lettuce } & \multicolumn{10}{|c|}{$30 \mathrm{obs}=29 \mathrm{df}=2.045$} \\
\hline & $\begin{array}{l}2006 \\
\text { Average }\end{array}$ & $\begin{array}{l}\text { Standard } \\
\text { Error }\end{array}$ & $\begin{array}{l}S^{*} \\
2.045\end{array}$ & $\begin{array}{l}\text { Lower } \\
\text { bound }\end{array}$ & $\begin{array}{l}\text { Upper } \\
\text { bound }\end{array}$ & $\begin{array}{l}\text { Spring } \\
06 / 07\end{array}$ & $\begin{array}{l}\text { Standard } \\
\text { Error }\end{array}$ & $\begin{array}{l}\mathrm{SE}^{*} \\
2.045\end{array}$ & $\begin{array}{l}\text { Lower } \\
\text { bound }\end{array}$ & $\begin{array}{l}\text { Upper } \\
\text { bound }\end{array}$ \\
\hline Control & 840 & 156 & 319 & 521 & 1159 & 1300 & 326 & 666 & 634 & 1966 \\
\hline $\begin{array}{l}\text { Row } \\
\text { Cover }\end{array}$ & 1028 & 156 & 319 & 709 & 1347 & 2083 & 326 & 666 & 1417 & 2750 \\
\hline $\begin{array}{l}\text { Row } \\
\text { Cover } \\
\text { with } \\
\text { water }\end{array}$ & 1197 & 156 & 319 & 878 & 1516 & 2205 & 326 & 666 & 1539 & 2871 \\
\hline $\begin{array}{l}\text { Low } \\
\text { Tunnel }\end{array}$ & 1062 & 156 & 319 & 743 & 1381 & 1712 & 326 & 666 & 1045 & 2378 \\
\hline $\begin{array}{l}\text { Low } \\
\text { Tunnel } \\
\text { with } \\
\text { water }\end{array}$ & 1097 & 156 & 319 & 778 & 1416 & 2375 & 326 & 666 & 1709 & 3041 \\
\hline $\begin{array}{l}\text { Cold } \\
\text { Frame }\end{array}$ & 1896 & 806 & & & & 3550 & 578 & & & \\
\hline $\begin{array}{l}\text { Cold } \\
\text { Frame } \\
\text { with } \\
\text { water }\end{array}$ & 1735 & 617 & & & & 3450 & 578 & & & \\
\hline
\end{tabular}


Radish

\begin{tabular}{|c|c|c|c|c|c|c|c|c|c|c|}
\hline & 2006 & $\begin{array}{l}\text { Standard } \\
\text { Error }\end{array}$ & $\begin{array}{l}\mathrm{SE}^{*} \\
2.045\end{array}$ & $\begin{array}{l}\text { Lower } \\
\text { bound }\end{array}$ & $\begin{array}{l}\text { Upper } \\
\text { bound }\end{array}$ & $\begin{array}{l}\text { Spring } \\
06 / 07\end{array}$ & $\begin{array}{l}\text { Standard } \\
\text { Error }\end{array}$ & $\begin{array}{l}\mathrm{SE}^{*} \\
2.045\end{array}$ & $\begin{array}{l}\text { Lower } \\
\text { bound }\end{array}$ & $\begin{array}{l}\text { Upper } \\
\text { bound }\end{array}$ \\
\hline Control & 2497 & 261 & 533 & 1963 & 3030 & 3255 & 259 & 530 & 2725 & 3785 \\
\hline $\begin{array}{l}\text { Row } \\
\text { Cover }\end{array}$ & 2163 & 261 & 533 & 1630 & 2697 & 2692 & 259 & 530 & 2161 & 3222 \\
\hline $\begin{array}{l}\text { Row } \\
\text { Cover } \\
\text { with } \\
\text { water }\end{array}$ & 2378 & 261 & 533 & 1845 & 2912 & 2788 & 259 & 530 & 2258 & 3319 \\
\hline $\begin{array}{l}\text { Low } \\
\text { Tunnel }\end{array}$ & 2213 & 261 & 533 & 1680 & 2747 & 2363 & 259 & 530 & 1833 & 2894 \\
\hline $\begin{array}{l}\text { Low } \\
\text { Tunnel } \\
\text { with } \\
\text { water }\end{array}$ & 2818 & 261 & 533 & 2285 & 3352 & 2897 & 259 & 530 & 2366 & 3427 \\
\hline $\begin{array}{l}\text { Cold } \\
\text { Frame }\end{array}$ & 5500 & 1404 & & & & 6200 & 423 & & & \\
\hline $\begin{array}{l}\text { Cold } \\
\text { Frame } \\
\text { with } \\
\text { water }\end{array}$ & 5350 & 3009 & & & & 5275 & 423 & & & \\
\hline
\end{tabular}

Arugula

\begin{tabular}{|l|r|r|r|r|r|}
\hline & Spring 07 & \multicolumn{1}{l}{$\begin{array}{l}\text { Standard } \\
\text { Error }\end{array}$} & $\begin{array}{l}\text { SE* } \\
\text { 2.045 }\end{array}$ & $\begin{array}{l}\text { Lower } \\
\text { bound }\end{array}$ & $\begin{array}{l}\text { Upper } \\
\text { bound }\end{array}$ \\
\hline Control & 1250 & 314 & 641 & 609 & 1891 \\
\hline $\begin{array}{l}\text { Row } \\
\text { Cover }\end{array}$ & 1420 & 314 & 641 & 779 & 2061 \\
\hline $\begin{array}{l}\text { Row } \\
\text { Cover } \\
\text { with } \\
\text { water }\end{array}$ & 1073 & 314 & 641 & 432 & 1715 \\
\hline $\begin{array}{l}\text { Low } \\
\text { Tunnel }\end{array}$ & 763 & 314 & 641 & 122 & 1405 \\
\hline $\begin{array}{l}\text { Low } \\
\text { Tunnel } \\
\text { with } \\
\text { water }\end{array}$ & 1137 & 314 & 641 & 495 & 1778 \\
\hline $\begin{array}{l}\text { Cold } \\
\text { Frame }\end{array}$ & 4900 & 348 & & & \\
\hline $\begin{array}{l}\text { Cold } \\
\text { Frame } \\
\text { with } \\
\text { water }\end{array}$ & 5150 & 348 & & & \\
\hline
\end{tabular}




\begin{tabular}{|c|c|c|c|c|c|c|c|c|c|c|}
\hline & 2006 & $\begin{array}{l}\text { Standard } \\
\text { Error }\end{array}$ & $\begin{array}{l}\mathrm{SE}^{*} \\
2.045\end{array}$ & $\begin{array}{l}\text { Lower } \\
\text { bound }\end{array}$ & $\begin{array}{l}\text { Upper } \\
\text { bound }\end{array}$ & $\begin{array}{l}\text { Spring } \\
06 / 07\end{array}$ & $\begin{array}{l}\text { Standard } \\
\text { Error }\end{array}$ & $\begin{array}{l}\mathrm{SE}^{*} \\
2.045\end{array}$ & $\begin{array}{l}\text { Lower } \\
\text { bound }\end{array}$ & $\begin{array}{l}\text { Upper } \\
\text { bound }\end{array}$ \\
\hline Control & 2248 & 490 & 1002 & 1246 & 3251 & 3087 & 857 & 1753 & 1334 & 4839 \\
\hline $\begin{array}{l}\text { Row } \\
\text { Cover } \\
\end{array}$ & 2382 & 490 & 1002 & 1379 & 3384 & 4908 & 857 & 1753 & 3156 & 6661 \\
\hline $\begin{array}{l}\text { Row } \\
\text { Cover } \\
\text { with } \\
\text { water }\end{array}$ & 3254 & 554 & 1133 & 2121 & 4387 & 6599 & 857 & 1753 & 4846 & 8352 \\
\hline $\begin{array}{l}\text { Low } \\
\text { Tunnel }\end{array}$ & 2415 & 490 & 1002 & 1413 & 3417 & 4852 & 857 & 1753 & 3099 & 6604 \\
\hline $\begin{array}{l}\text { Low } \\
\text { Tunnel } \\
\text { with } \\
\text { water }\end{array}$ & 3748 & 490 & 1002 & 2746 & 4751 & 7026 & 857 & 1753 & 5273 & 8779 \\
\hline $\begin{array}{l}\text { Cold } \\
\text { Frame }\end{array}$ & 4780 & 2608 & & & & 9853 & 1080 & & & \\
\hline $\begin{array}{l}\text { Cold } \\
\text { Frame } \\
\text { with } \\
\text { water }\end{array}$ & 6565 & 2272 & & & & 12830 & 1080 & & & \\
\hline
\end{tabular}

\section{Tomato}

\begin{tabular}{|c|c|c|c|c|c|c|c|c|c|c|}
\hline & 2006 & $\begin{array}{l}\text { Standard } \\
\text { Error }\end{array}$ & $\begin{array}{l}\mathrm{SE}^{*} \\
2.045\end{array}$ & $\begin{array}{l}\text { Lower } \\
\text { bound }\end{array}$ & $\begin{array}{l}\text { Upper } \\
\text { bound }\end{array}$ & $\begin{array}{l}\text { Spring } \\
06 / 07\end{array}$ & $\begin{array}{l}\text { Standard } \\
\text { Error }\end{array}$ & $\begin{array}{l}\mathrm{SE}^{*} \\
2.045\end{array}$ & $\begin{array}{l}\text { Lower } \\
\text { bound }\end{array}$ & $\begin{array}{l}\text { Upper } \\
\text { bound }\end{array}$ \\
\hline Control & 1425 & 1477 & 3021 & -1596 & 4446 & 6100 & 6968 & 14249 & -13136 & 15361 \\
\hline $\begin{array}{l}\text { Row } \\
\text { Cover }\end{array}$ & 8365 & 1477 & 3021 & 5344 & 11386 & 15598 & 3455 & 7066 & 9789 & 23921 \\
\hline $\begin{array}{l}\text { Row } \\
\text { Cover } \\
\text { with } \\
\text { water }\end{array}$ & 11065 & 1477 & 3021 & 8044 & 14086 & 22065 & 2774 & 5672 & 17390 & 28735 \\
\hline $\begin{array}{l}\text { Low } \\
\text { Tunnel }\end{array}$ & 8391.7 & 1477 & 3021 & 5371 & 11413 & 13393 & 2774 & 5672 & 8718 & 20062 \\
\hline $\begin{array}{l}\text { Low } \\
\text { Tunnel } \\
\text { with } \\
\text { water }\end{array}$ & 10280 & 1477 & 3021 & 7259 & 13301 & 15646 & 2774 & 5672 & 10971 & 22315 \\
\hline $\begin{array}{l}\text { Cold } \\
\text { Frame }\end{array}$ & 16550 & 12487 & & & & 27400 & 2524 & & & \\
\hline $\begin{array}{l}\text { Cold } \\
\text { Frame } \\
\text { with } \\
\text { water }\end{array}$ & 18070 & 15115 & & & & 27970 & 2524 & & & \\
\hline
\end{tabular}




\section{Appendix D- Regression Analyses}

Regression Analysis for Spring Seasons 2006 and 2007

\begin{tabular}{|l|l|l|l|l|l|l|}
\hline & & Lettuce & Radish & Arugula & Pepper & Tomato \\
\hline Air & F ratio & 12.21 & 1.33 & 4.28 & 15.41 & 22.41 \\
\hline & P value & 0.0014 & 0.26 & 0.056 & 0.0004 & $<0.0001$ \\
\hline & $R^{2}$ value & 0.28 & 0.04 & 0.22 & 0.33 & 0.41 \\
\hline Soil & F ratio & 14.68 & 8.08 & 46.73 & 24.19 & 22.13 \\
\hline & P value & 0.0006 & 0.0081 & $<0.0001$ & $<0.0001$ & $<0.0001$ \\
\hline & $R^{2}$ value & 0.34 & 0.22 & 0.80 & 0.45 & 0.43 \\
\hline
\end{tabular}

Regression Analysis for Fall Season 2006

\begin{tabular}{|l|l|l|l|l|l|}
\hline & & Lettuce & Radish & Pepper & Tomato \\
\hline Air & F ratio & 28.73 & 18.64 & 11.98 & 13.98 \\
\hline & P value & $<0.0001$ & 0.0006 & 0.0035 & 0.002 \\
\hline & $R^{2}$ value & 0.66 & 0.55 & 0.44 & 0.48 \\
\hline Soil & F ratio & 27.60 & 35.61 & 18.62 & 17.48 \\
\hline & $P$ value & $<0.0001$ & $<0.0001$ & 0.0006 & 0.0008 \\
\hline & $R^{2}$ value & 0.65 & 0.70 & 0.55 & 0.54 \\
\hline
\end{tabular}




\section{Appendix E- Early Yield Analyses}

Early Yield Analyses for Spring 2006/2007- GLM for an ANOVA Pepper

\begin{tabular}{|l|l|l|l|}
\hline Source & DF & F Ratio & Probability \\
\hline Treatment & 5 & 8.71 & 0.0004 \\
\hline Year & 1 & 57.25 & $<0.0001$ \\
\hline Trt*Year & 5 & 1.19 & 0.36 \\
\hline $\mathrm{H}_{2} \mathrm{O}$ contrast & 1 & 9.78 & 0.0065 \\
\hline
\end{tabular}

Tomato

\begin{tabular}{|l|l|l|l|}
\hline Source & DF & F Ratio & Probability \\
\hline Treatment & 5 & 320.01 & $<0.0001$ \\
\hline Year & 1 & 94.82 & $<0.0001$ \\
\hline Trt*Year & 5 & 15.26 & $<0.0001$ \\
\hline $\mathrm{H}_{2} \mathrm{O}$ contrast & 1 & 2.66 & 0.12 \\
\hline
\end{tabular}




\section{Appendix F- Frost/ Freeze Data}

Climatography of the United States

No. 20 1971-2000

\author{
National Oceanic \& Atmospheric Administration \\ National Environmental Satellite, Data, \\ and Information Service \\ National Climatic Data Center \\ Federal Building \\ 151 Patton Avenue \\ Asheville, North Carolina 28801 \\ www.ncdc.noaa.gov
}

\section{Station: MORGANTOWN HART AP, WV \\ Elevation: 1,240 Feet Lat: 39 39N Lon: 79 \\ Climate Division: WV 2 NWS Call Sign: MGW 55W \\ COOP ID: 466202}

\section{Freeze Data}

Spring Freeze Dates (Month/Day)

Temp (F)

Probability of later date in spring (thru Jul 31) than indicated(*)

$\begin{array}{lllllllll}.10 & .20 & .30 & .40 & .50 & .60 & .70 & .80 & .90\end{array}$

36 5/25 5/20 5/16 5/13 5/09 5/06 5/03 4/29 4/24

$325 / 18$ 5/12 5/07 5/04 4/30 4/27 4/23 4/18 4/12

28 4/28 4/23 4/19 4/16 4/13 4/10 4/06 4/03 3/28

24 4/15 4/11 4/07 4/04 4/02 3/30 3/27 3/23 3/19

20 4/06 4/01 3/28 3/24 3/21 3/18 3/14 3/11 3/05

$163 / 313 / 233 / 183 / 133 / 093 / 042 / 28$ 2/22 2/15

\section{Fall Freeze Dates (Month/Day)}

\section{Temp (F)}

Probability of earlier date in fall (beginning Aug 1) than indicated(*)

$\begin{array}{lccccccccc} & \mathbf{. 1 0} & \mathbf{. 2 0} & \mathbf{. 3 0} & \mathbf{. 4 0} & \mathbf{. 5 0} & \mathbf{. 6 0} & \mathbf{. 7 0} & \mathbf{. 8 0} & \mathbf{. 9 0} \\ \mathbf{3 6} & 9 / 20 & 9 / 24 & 9 / 28 & 10 / 01 & 10 / 04 & 10 / 06 & 10 / 09 & 10 / 13 & 10 / 17 \\ \mathbf{3 2} & 10 / 01 & 10 / 07 & 10 / 11 & 10 / 14 & 10 / 18 & 10 / 21 & 10 / 25 & 10 / 29 & 11 / 03 \\ \mathbf{2 8} & 10 / 15 & 10 / 20 & 10 / 23 & 10 / 26 & 10 / 29 & 11 / 01 & 11 / 04 & 11 / 07 & 11 / 12 \\ \mathbf{2 4} & 10 / 25 & 10 / 31 & 11 / 05 & 11 / 08 & 11 / 12 & 11 / 15 & 11 / 19 & 11 / 23 & 11 / 29 \\ \mathbf{2 0} & 11 / 04 & 11 / 11 & 11 / 16 & 11 / 20 & 11 / 24 & 11 / 28 & 12 / 02 & 12 / 07 & 12 / 14 \\ \mathbf{1 6} & 11 / 18 & 11 / 25 & 11 / 29 & 12 / 03 & 12 / 07 & 12 / 11 & 12 / 15 & 12 / 19 & 12 / 26\end{array}$

Freeze Free Period

Temp (F)

Probability of longer than indicated freeze free period (Days)

$\begin{array}{lllllllll}.10 & .20 & .30 & .40 & .50 & .60 & .70 & .80 & .90\end{array}$

36166159154150146142138134127

32197187181175170165159152143

28222214208203199194189183175

24246238233228223219214208201

20276266259253247242236229219

16300291284278273267262255246

* Probability of observing a temperature as cold, or colder, later in the spring or earlier in the fall than the indicated date.

0/00 Indicates that the probability of occurrence of threshold temperature is less than the indicated probability.

Derived from 1971-2000 serially complete daily data Complete documentation available from:

www.ncdc.noaa.gov/oa/climate/normals/usnormals.html 


\section{Appendix G- The Planting Date Determination Model}

Season extension can play a key role in many vegetable production systems. This lengthening of harvest times can increase both early and total yield and therefore increase profitability for vegetable growers. However, before implementation, growers have to make decisions about what season extension methods should be used for their desired crops and markets and when these crops should be planted. The main components of any planting date decision for growers are long-term frost/freeze data, season extension techniques used, and the crops grown in these systems along with short- term local forecasts. The goal in constructing a planting date determination model was to create a tool for vegetable growers that would allow for a simple, easy, and clear way to calculate planting dates based on location, season extension method, crops, and weather forecasts.

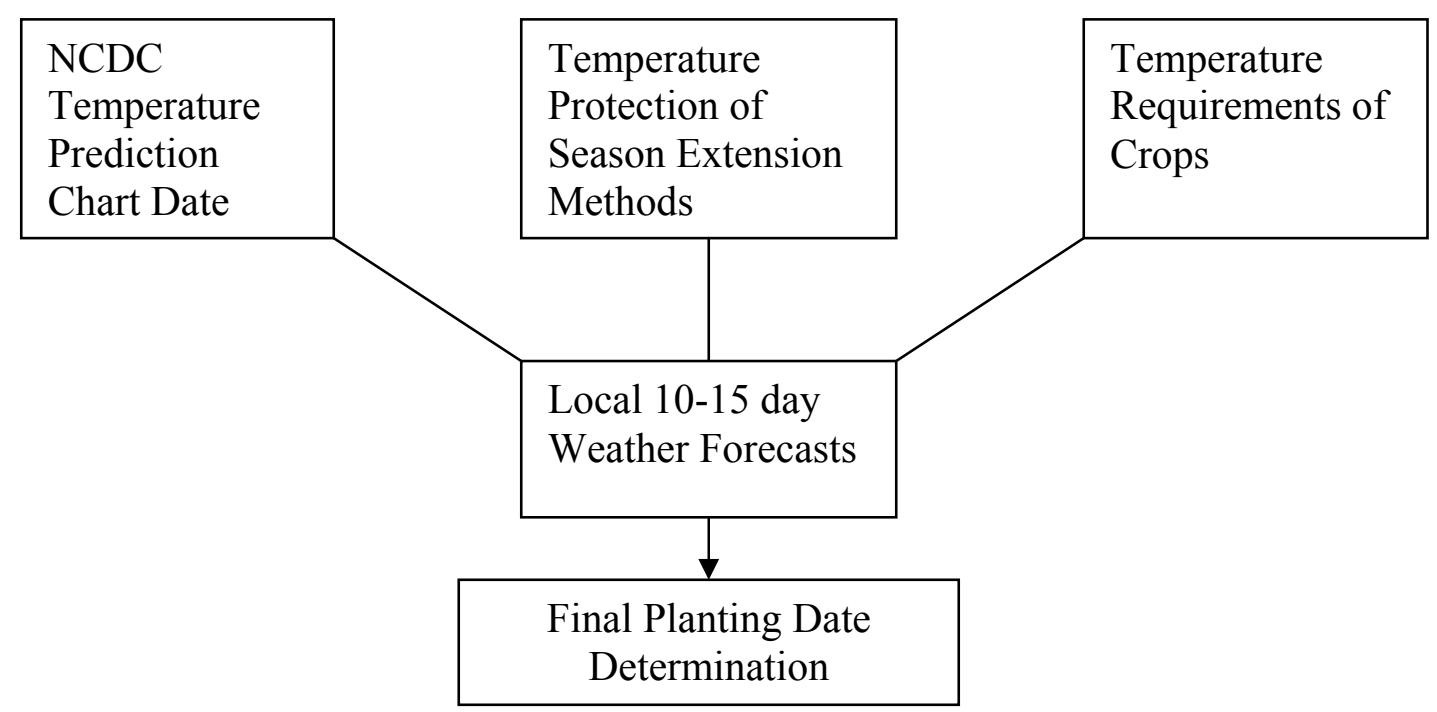




\section{Climate Data:}

The National Climactic Data Center gathers and records climate data from weather stations across the U.S. and has for many years. This long-term climate data is available in many different forms on the NCDC website. The climatography report \#20 is a free report for all weather stations in the U.S. that compiles thirty-year climactic averages from 1971 through 2000. A part of this climatography report is a frost/freeze prediction chart that provides expected last and first dates of occurrence for set minimum temperatures and the probability of lower temperatures occurring after this date in the spring or before this date in fall (Appendix F).

Growers can obtain this climatography report free for the weather station that best applies to their growing site and conditions. By using the planting dates and probabilities found on this chart, they can calculate planting times based on temperatures demanded by specific crops and the levels of temperature protection provided by differing season extension techniques.

Additionally, the presence of differing probabilities allows growers to choose planting dates that have a high or low risk of temperature damage for their cropping systems. The integration of this information will be discussed in following sections of this appendix.

\section{Temperature Protection of Season Extension Methods:}

Six season extension techniques along with a control were tested for use in this planting date model. The first treatment consisted of a spun bonded polypropylene row cover (Agribon 19, 0.55 oz/yd, Johnny's Selected Seeds. Wolcott, VT) spread over 10 gauge wire hoops. The second treatment incorporated this same row cover material with the addition of 30 linear meters of $15 \mathrm{~cm}$ diameter 6 mil polyethylene tubes filled with water to moderate temperatures. The third treatment incorporated a 0.5 mil slitted polyethylene low tunnel (Hummert's Horticultural 
Supply Earth City, MO) stretched across 10 gauge wire hoops. The fourth treatment used the same low tunnel material as treatment 3 with the addition of water tubes as described in treatment 2. Treatments 5 and 6 were carried out in two $6 \mathrm{~m} \times 7.6 \mathrm{~m}$ single layer polyethylene cold frames. Treatment 6 included the use of $1150 \mathrm{~L}$ of water (in plastic milk jugs) on shelves in the center of the cold frame to moderate temperatures and a $9.0 \mathrm{~m}^{3}$ compost pile on the north side of the cold frame to passively supply additional heat.

One of the objectives of this model was to determine the level of temperature moderation that could be expected of each season extension technique tested. Season extension methods have been shown to increase the average air temperature in the crop microclimate over 24-hour periods. Daytime temperature and the addition of heat units in the early portion of the growing season are important components in increasing yield in experimental treatments. However, the increase in daytime temperature is not important when night time low temperatures cause tissue damage or plant death. Therefore, any model recommending planting dates for specific season extension methods should take into account minimum temperatures. Air temperatures in ${ }^{\circ} \mathrm{F}$ were used for this model because they correspond with the published data of the NCDC and are the most common heat unit used by growers in the U.S.

Expected levels of temperature protection were used in the design of the model and tested for accuracy by the temperatures collected during this study. The row cover and low tunnel treatments, in addition to the cold frame without water jugs were assumed to provide $4{ }^{\circ} \mathrm{F}$ temperature cushion. These temperature protection estimates were taken from the manufacturer (see above) recommendations. The cold frame with water and compost was assumed to provide $8^{\circ} \mathrm{F}$ minimum temperature increase because of the inclusion of water and compost heating. 
Air temperatures were measured using a Spectrum model 125 data logger (Spectrum Technologies, East Plainfield IL). Temperature measurements were taken hourly and the minimum temperature for every day was recorded and averaged over the time period covers were in place (early April through mid June) to obtain an overall season extension treatment average.

The spring 2006 average minimum temperature (Table 1$)$ of the control $\left(45.1^{\circ} \mathrm{F}\right)$ was the lowest observed minimum temperature average. Row cover $\left(48.1^{\circ} \mathrm{F}\right)$, row cover with water $\left(49.2^{\circ} \mathrm{F}\right)$, and cold frame with water $\left(51.4^{\circ} \mathrm{F}\right)$ all showed higher temperatures than the control and low tunnel treatments. Cold frame $\left(47.4^{\circ} \mathrm{F}\right)$, low tunnel $\left(45.3^{\circ} \mathrm{F}\right)$, and low tunnel with water $\left(46.0^{\circ} \mathrm{F}\right)$ treatments showed comparable temperatures to the control.

The spring 2007 average minimum air temperature (Table 2$)$ of the control $\left(47.8^{\circ} \mathrm{F}\right)$ showed the lowest temperature among all treatments. The cold frame with water treatment $\left(51.5^{\circ} \mathrm{F}\right)$ minimum air temperature was higher than the low tunnel treatment $\left(48.2^{\circ} \mathrm{F}\right)$ and the control. Row cover $\left(49.1^{\circ} \mathrm{F}\right)$, row cover with water $\left(49.6^{\circ} \mathrm{F}\right)$, low tunnel, low tunnel with water $\left(49.5^{\circ} \mathrm{F}\right)$, and cold frame treatments showed only trends toward higher temperatures.

The increases in temperature represented in Table 3 are the average of the temperature increases seen in both the springs of 2006 and 2007. The cold frame with water showed the highest average increase in minimum air temperature $\left(5.2^{\circ} \mathrm{F}\right)$ while the low tunnel without water showed the lowest average increase over the control $\left(0.4^{\circ} \mathrm{F}\right)$. The treatments with water all showed higher temperature increases than those without water. The cold frame treatments, showed the highest elevation in average temperatures while the temperature increase in the two low tunnel treatments was the lowest. 
Table 1: Average Minimum Air Temperatures for the Spring 2006 Season (4/2- 6/13) Each treatment average represents the average temperatures throughout the season. SE is the standard error of the mean ( $\mathrm{N}=73$ days). Letters denote differences between treatments. Treatments with the same letter are not significantly different from each other.

\begin{tabular}{llll}
\hline & Differences & ${ }^{\circ}$ F Average & SE \\
\hline Control & $\mathrm{A}$ & 45.1 & 1.1 \\
Row Cover & $\mathrm{BC}$ & 48.1 & 1.0 \\
Row Cover with water & $\mathrm{CD}$ & 49.2 & 1.0 \\
Low Tunnel & $\mathrm{A}$ & 45.3 & 1.0 \\
Low Tunnel with water & $\mathrm{AB}$ & 46.0 & 1.0 \\
Cold Frame & $\mathrm{ABC}$ & 47.4 & 1.0 \\
Cold Frame with water & $\mathrm{D}$ & 51.4 & 0.9 \\
ANOVA & & $* * *$ &
\end{tabular}

NS, ${ }^{*} * *, * * *$ Nonsignificant or significant at $\mathrm{P}=0.05,0.01,0.001$, respectively

Table 2: Average Minimum Air Temperatures for the Spring 2007 Season (4/10-6/11) Each treatment average represents the average temperatures throughout the season. SE is the standard error of the mean ( $\mathrm{N}=63$ days). Letters denote differences between treatments. Treatments with the same letter are not significantly different from each other.

\begin{tabular}{llll}
\hline & Differences & ${ }^{\circ}$ F Average & SE \\
\hline Control & $\mathrm{A}$ & 47.5 & 1.1 \\
Row Cover & $\mathrm{AB}$ & 49.1 & 1.2 \\
Row Cover with water & $\mathrm{AB}$ & 49.6 & 1.2 \\
Low Tunnel & $\mathrm{A}$ & 48.2 & 1.2 \\
Low Tunnel with water & $\mathrm{AB}$ & 49.5 & 1.2 \\
Cold Frame & $\mathrm{AB}$ & 50.7 & 1.2 \\
Cold Frame with water & $\mathrm{B}$ & 51.5 & 1.2 \\
ANOVA & & $\mathrm{NS}$ &
\end{tabular}

$\mathrm{NS}, * * *, * * *$ Nonsignificant or significant at $\mathrm{P}=0.05,0.01,0.001$, respectively

Table 3: Average Increase in Minimum Air Temperatures for 2006 and 2007

\begin{tabular}{lllllll}
\hline & Row & Row $\mathbf{H}_{2} \mathbf{0}$ & Low & Low $\mathbf{H}_{2} \mathbf{0}$ & $\mathbf{C F}$ & $\mathbf{C F} \mathbf{H}_{\mathbf{2}} \mathbf{0}$ \\
\hline Increase $^{\circ} \mathbf{F}$ & 2.3 & 3.1 & 0.4 & 1.5 & 2.8 & 5.2 \\
\hline
\end{tabular}




\section{Temperature Requirements for Crops:}

When determining planting dates, it is necessary to know minimum temperature requirements for all vegetable crops in the production system. These requirements allow the grower to know the minimum temperature level from which to calculate planting dates. Vegetable crops differ in temperature requirements both for survival and optimum productivity. Seed suppliers and vegetable production guides should be consulted for specific crops requirements to determine exact crop requirements (Table 4). However, vegetable crops broadly fall into the two categories of warm and cool season crops, which will be used as examples in this model. Warm season crops, such as melons and tomatoes would need a minimum temperature of $32^{\circ} \mathrm{F}$ or higher. Planting dates for cool season crops, such as lettuce and radishes could be calculated from a lower minimum temperature threshold, such as $20^{\circ} \mathrm{F}$ or $25^{\circ} \mathrm{F}$.

Table 4: Minimum Plant Growth Temperatures for some Warm and Cool Season Crops

\begin{tabular}{ll}
\hline Vegetable Crop & Minimum Air Temperatures $\left({ }^{\circ} \mathbf{F}\right)$ \\
\hline Romine Lettuce & 20 to 30 \\
Arugula & 20 to 30 \\
Radish & 20 to 30 \\
Tomato & 32 \\
Bell Peppers & 32 to 39 \\
\hline
\end{tabular}




\section{Planting Date Determination:}

Planting dates in this model are obtained by using a set probability level from the NCDC frost/freeze chart from a weather station applicable to grower. The examples in this discussion will use the 0.10 probability level as it is the most conservative estimate and ensures the highest level of crop survival. The minimum temperature threshold for the crop in question is the first step. As an example, spring tomatoes requiring a minimum of $32^{\circ} \mathrm{F}$ will be planted. These minimum temperatures are then used to determine the dates from Appendix F (NCDC frost/freeze chart for Hart Field Airport weather station in Morgantown, WV). In this example, the 0.10 probability date for $32^{\circ} \mathrm{F}$ is May $18^{\text {th }}$. The $5^{\circ} \mathrm{F}$ temperature protection provided by the cold frame with water as listed in Table 3 would allow the use of the planting date $(0.10$ probability) of $28^{\circ} \mathrm{F}$ instead of $32{ }^{\circ} \mathrm{F}$. This would allow our planting date to be April $28^{\text {th }}$ instead of May $18^{\text {th }}$, an increase in the length of our season by almost 3 weeks.

The temperature protection of 2 to $3^{\circ} \mathrm{F}$ provided by the row cover and row cover with water treatment could likewise allow earlier planting. Instead of May $18^{\text {th }}$, tomatoes grown under these season extension methods could be planted in early May and lengthen the season by approximately two weeks. The low tunnel treatments gave little temperature protection and minimum temperatures were similar to the control temperatures. These methods could increase daytime temperatures and aid in growth, but provided little in the way of minimum temperature increases. Cool season crop planting dates would be calculated in this same manner, but the planting dates would correspond to $20^{\circ} \mathrm{F}$ or $24^{\circ} \mathrm{F}$ minimum temperature thresholds from the NCDC frost/freeze chart.

This planting date obtained through consulting climate, crop requirements, and season extension methods should then be used in conjunction with the current 10 to 15-day forecast to 
determine the actual planting date. If the local forecast predicted temperatures appropriate for planting, the exact model date can be used. However, if local expected temperatures were to be too low for the spring crop in question, planting should be postponed until the local forecast corresponded with known crop attributes. These adjustments are made to prevent premature planting when subsequent temperatures may injure or kill young plants. Moisture conditions and soil readiness to till is also a factor in determining spring planting dates.

Fall planting dates are obtained in a similar fashion. Dates of minimum temperature thresholds in the fall are located for specific crops. These dates are adjusted according to the season extension method used. This approximate date when harmful low temperatures are likely is used as the end of the season date. Days to maturity for the crop to be planted are then counted backwards from this date to obtain a planting date.

This model could also be used to make decisions on what additional inputs the grower would choose to invest in. Different systems, as seen in this work, provide varying benefits. Lower cost methods, such as row covers can be used by growers to lengthen the season and increase early yields even if cold frames or high tunnels are too great an initial expense. Likewise, the addition of water to these growing systems can aid in minimum temperature enhancement thereby providing more temperature protection and allowing an earlier planting date. Taken together, we envision growers reaching production goals by using this model to integrate their cropping schedule and production system. 


\section{References}

Abdul-Baki, A.A., and J. R. Teasdale. 1997. Snap Bean Production on Conventional Tillage and in No-till Hairy Vetch Mulch. Hort Science. 32(7): 1191-1193.

Abdul-Baki, A.A., J. R. Teasdale, R.W. Goth, K.G. Haynes. 2001. Marketable Yields of Freshmarket Tomatoes Grown in Plastic and Hairy Vetch mulch. Hort Science. 37(6): 878-881.

Abdul-Baki, A.A., A.E. Watada, J.R. Teasdale, R.D. Morse. 1996. Hairy Vetch Mulch Favorably Impacts Yield of Processing Tomatoes. Hort Science. 31(3): 338-340.

Aguyoh, J., H. Taber, and V. Lawson. 1999. Maturity of Fresh market Sweetcorn with Direct Seeded Plants, Transplants, Clear Mulch, and Plastic Rowcover Combinations. Hort Technology. $9(3): 420-425$.

Avilla, C., J. Collar, M. Duque, P. Perez, and A Fereres. 1997. Impact of Floating Rowcovers on Bell Pepper Yield and Virus Incidence. Hort Science. 32(5): 882-883.

Aziz, F., K.A. Stewart, and S. Jenni. 2001. Early Growing of Muskmelon in Mulched Minitunnels Containing a Thermal Water Tube. II. Air Soil, and Water Tube Temperatures and Vegetative Growth. J. Amer. Soc. Hort. Sci. 126(6): 764-770.

Aziz, F., K.A. Stewart, and S. Jenni. 2001. Early Growing of Muskmelon in Mulched Minitunnels Containing a Thermal Water Tube. I. Carbon Dioxide Concentrations in the Tunnel. J. Amer. Soc. Hort. Sci. 126(6): 757-763.

Bachmann, J. 2005. Season Extension Techniques for Market Gardeners. ATTRA. www.attra.ncat.org (Accessed 25 Oct 2007).

Bellows, B. 2003. Solar Greenhouses. ATTRA. www.attra.ncat.org /attra-pub/solar-gh.html (Accessed 13 Nov 2007).

Cavins, T.J., J.M. Dole, and V. Stamback. 2000. Unheated and Minimally Heated Winter Greenhouse Production of Specialty Cut Flowers. Hort Technology. 10 (4):

793-799.

Choi, C.Y., W. Zimmt, G. Giacomelli. 1999. Freeze and Frost Protection with Aqueous FoamFoam Development. Hort Technology. 9(4)

Coleman, Eliot. 1999. Four Season Harvest: Organic Vegetables From Your Home Garden All Year Long. Chelsea Green Publishing Co., White River Junction, VT.

Coltrain, D. and L. Jett. Tomato Budget for 1000 square foot High Tunnel.

http://www.hightunnels.org/ForGrowers/WarmSeasonVegetables/warmseasonvegbudget.htm

(Accessed 26 November 2007) 
Csizinszky, A.A., D.J. Schuster, and J.B. King. 1995. Color Mulch Influence Yield and Insect Pest Populations in Tomatoes. J. Amer. Soc. Hort. Sci. 120(5): 778-784.

Dangler, J.M. 1994. Rowcovers Improve Sweet potato Transplant Production in Field Beds and Hotbeds. Hort Technology. 4(1): 57-60.

Decoteau, D.R. 2000. Vegetable Crops. Prentice Hall, Upper Saddle River, NJ.

Diver, S. 2001. Compost Heated Greenhouses. ATTRA. www.attra.ncat.org (Accessed 13 Nov 2007).

Eckert, D. and J. T. Sims. 1995. Recommended soil pH and Lime Requirement Tests. In Recommended Soil Testing Procedures for the Northeastern United States, $2^{\text {nd }}$ edition. Univ. of Delaware Agric. Exp. Stn. Bull. 493.

Fernandez, G. 2001. Fall-applied Rowcovers Enhance Yield in Plasticulture Strawberries. Hort Technology. 11(3): 440-444.

Fulford, B. 1983. Biothermal Energy: Cogenerants of Thermophylic Composting and Their Integration Within Food Producing and Waste Recycling Systems. New Alchemy Institute, East Falmouth, MA.

Hanna, H.Y. 2000. Black Polyethylene Mulch Does Not Reduce Yield of Cucumbers DoubleCropped with Tomatoes under heat Stress. Hort Science. 35(2): 190-191.

Hodges, L., and J.R. Brandle. 1996. Windbreaks: An Important Component in a Plasticulture System. Hort Technology. 6(3): 177-182.

Jenni, S., K. Stewart, D.C. Cloutier, and G. Bourgeois. 1998. Chilling Injury and Yield of Muskmelon Grown with Plastic Mulches, Rowcovers, and Thermal Water Tubes. Hort Science. 33(2): 215-221.

Kelly, K. 2005. Shade-Covered High Tunnels for Summer Production of Lettuce and Leafy Greens. Organic Farming Research Foundation.

Lamont, W.J. 1996. What Are the Components of a Plasticulture System? Hort Technology. 6(3): $150-154$.

Lamont, W.J. 2005. Plastics: Modifying the Microclimate for the Production of Vegetable Crops. Hort Technology. 15(3): 477-481.

Lamont, W.J., M.R. McGann, M.D. Orzolek, N. Mbugua, B. Dye, and D. Reese. 2003. Design and Construction of the Penn State High Tunnel. Hort Technology. 12(3): 447-453.

Marr, C., W.J. Lamont, and M. Allison. 1991. Rowcovers Improve Seedless Watermelon Yields in an Intensive Vegetable Production System. Hort Technology. Oct./Dec. 103-104. 
McCullagh, J.C. 1978. The Solar Greenhouse Book. Rhodale Press, Emmaus, PA.

Moreno, D.A., G. Villora, J. Hernandez, N. Castilla, L. R. Monreal. 2002. Yield and Chemical Composition of Chinese Cabbage in Relation to Thermal Regime as Influenced by Row Covers. J. Amer. Soc. Hort. Sci. 127(3): 343-348.

NCDC Climatography of the United States No. 20 Freeze/Frost Maps. http://www.ncdc.noaa.gov (Accessed 2 Nov 2007).

NCDC Climatography of the United States No. 84. http://www.ncdc.noaa.gov (Accessed 2 Nov 2007).

NRCS. Soil Survey Manual. 1993. http://soils.usda.gov/technical/manual /contents/chapter3d.html. (Accessed 26 Nov 2007)

Peirce, L.C., and M.L. Crispi. 1989. Relationship Between Flowering and Ripening Dates Modified in Tomatoes by Polyethylene Mulch and Row Covers. Hort Science. 24(5): 781-782.

Perry, K.B. 1998. Basics of Frost and Freeze Protection for Horticultural Crops. Hort Technology. 8(1): 10-15.

Peterson, R.H., and H.G. Taber. 1991. Tomato Flowering and early Yield Response to Heat Buildup under Rowcovers. J. Amer. Hort. Sci. 116(2): 206-209.

Poling, E.B., H.P. Fuller, and K.B. Perry. 1991. Frost/Freeze Protection of Strawberries Grown on Black Plastic Mulch. Hort Science. 26(1): 15-17.

Popper, V. 2007. Aztec Agriculture. <http://www.su.edu/faculty/steabo/twolford555/ aztec_agriculture.htm>

Rader, H.B., and M.G. Karlsson. 2006. Northern Field Production of Leaf and Romaine Lettuce using a High Tunnel. Hort Technology. 16(4): 649-654.

Reiners, S., and P.J. Nitzsche. 1993. Rowcovers Improve Early Season Tomato Production. Hort Technology. Apr./June. 197-199.

Roth, G. 1996. Crop Rotation and Conservation Tillage. http://cropsoil.psu.edu/ extension/ct/uc124.pdf (Accessed 26 November 2007)

Seidel, G., S. Wearden.2005,2007. Personal Statistical Communication.

Selders, A.W. 1970. Frost Protection with Sprinkler Irrigation. Agricultural Engineering Bulletin SW-4. 
Soltani, N., L. Anderson, A.R. Hamson. 1995. Growth Analysis of Watermelon Plants Grown with Mulches and Rowcovers. J. Amer. Hort. Sci. 120(6): 1001-1009.

Taiz, L. and E. Zeiger. 2002. Plant Physiology. Sinauer Associates Inc., Publishers, Sunderland, MA.

Tarara, J.M. 2000. Microclimate Modification with Plastic Mulch. Hort Science. 35(2): 169-177.

Teasdale, J.R., and A.A. Abdul-Baki. 1995. Soil Temperature and Tomato Growth Associated with Black Polyethylene and Hairy Vetch Mulch. J. Amer. Soc. Hort. Sci. 120(5):848-853.

UK.2007. Season Extension Tools and Techniques. http://www.uky.edu/Ag/NewCrops /introsheets/extension.pdf (Accessed 14 Nov 2007).

USDA Code of Federal Regulations National Organic Program. 2002.

http://ecfr.gpoaccess.gov/cgi/t/text/text-idx?c=ecfr;sid=11fd57b422b6314d866

dc4b02fla101d;rgn=div5; view=text;node=7:3.1.1.9.30;idno=7; $\mathrm{cc}=$ ecfr $($ Accessed 30 Oct 2007).

Vavrina, C.S., and F.M. Roka. 2000. Comparison of Plastic Mulch and bare-ground Production and Economics for Short-day Onions in a Semitropical Environment. Hort Technology. 10(2): 326-330.

Walters, S.A. 2003. Suppression of Watermelon Mosaic Virus in Summer Squash with Plastic Mulches and Rowcovers. Hort Technology. 13(2): 352-357.

Waterer, D., 2003. Yields and Economics of High Tunnels for Production of Warm-Season Vegetable Crops. Hort Technology. 13(2): 339-343.

Wells, O.S., and B.J. Loy. 1993. Rowcovers and High Tunnels Enhance Crop Production in the Northeastern United States. Hort Technology. 3(1): 92-95.

Wells, O.S. 1996. Rowcovers and High Tunnel Growing Systems in the United States. Hort Technology. 6(3): 172-176.

Westcott, M.P., N.W. Callen, and M.L. Knox. 1991. Planting Date and Rowcover Interactions in Broccoli Production in Cold Climates. Hort Science. 26(9):1221.

Wittwer, S.H., and N. Castilla. 1995. Protected Cultivation of Horticultural crops Worldwide. Hort Technology. 5(1): 6-22.

Wolf, A. and D. Beegle. 1995. Recommended soil tests for macronutrients: phosphorus, potassium, calcium, and magnesium. In Recommended Soil Testing Procedures for the Northeastern United States, $2^{\text {nd }}$ edition. Univ. of Delaware Agric. Exp. Stn. Bull. 493. 
Zhang, D., J.R. Brandle, L. Hodges, E. Daningsih, and K. G. Hubbard. 1999. The Response of Muskmelon Growth and Development to Microclimate Modifications by Shelterbelts. Hort Science. 34(1): 64-68. 